UNIVERSIDADE DE SÃO PAULO

FACULDADE DE FILOSOFIA, LETRAS E CIÊNCIAS HUMANAS DEPARTAMENTO DE CIÊNCIA POLÍTICA PROGRAMA DE PÓS-GRADUAÇÃO EM CIÊNCIA POLÍTICA

ANILDO LOPES RODRIGUES

\title{
A Democracia Cabo-verdiana e os Pequenos Partidos Políticos
}

\author{
VERSÃO CORRIGIDA \\ O exemplar original se encontra disponível no CAPH da FFLCH (Centro de Apoio à \\ Pesquisa Histórica)
}

SÃO PAULO

2015 


\title{
ANILDO LOPES RODRIGUES
}

A Democracia Cabo-verdiana e os Pequenos Partidos Políticos

Dissertação apresentada à Faculdade de Filosofia, Letras e Ciências Humanas, da Universidade de São Paulo, para a obtenção do título de Mestre em Ciência Política.

Em acordo com a versão corrigida

Orientador: Prof. Dr. Paolo Ricci

\begin{abstract}
VERSÃO CORRIGIDA
O exemplar original se encontra disponível no CAPH da FFLCH (Centro de Apoio à Pesquisa Histórica)
\end{abstract}

\section{SÃO PAULO}




\section{Agradecimentos}

Essa dissertação é fruto de um longo processo e para sua concretização várias pessoas contribuíram direta ou indiretamente. Começo por agradecer ao meu bom Deus todo poderoso, por me ter dado forças espirituais para continuar essa longa caminhada, apesar das dificuldades.

Nesse momento não poderia de esquecer a minha querida família, por ter confiado em mim, apoiando-me nos momentos mais difíceis. Aos meus pais: João e Paula que apesar da distância e muita preocupação sempre transmitem muita energia positiva. Também a todos os meus irmãos e sobrinhos que sempre me dão animo para lutar com o único objetivo de vencer.

Ao meu orientador, Prof. Dr. Paolo Ricci por ter ajudado no meu crescimento e maturação académicos. Apesar das dificuldades, sempre esteve disponível para conversar e me orientar no que fosse preciso.

Aproveito para agradecer ao Prof. Dr. Bruno Speck e Prof. Dr. Wagner Mancuso pelos comentários e sugestões feitos durante a qualificação. A todos os professores e funcionários do Departamento da Ciência Política, em especial os Professores Doutores: Rogério Arantes, Fernando Limongi, Martha Arrecthe e Eduardo Marques; e aos funcionários, Raimunda, Vasne e Leonardo.

A todos os meus amigos brasileiros e colegas do departamento de ciência política, em especial ao Fabio Lacerda que me acolheu desde que cheguei ao Brasil, apoiando-me em tudo que precisei e contribuindo para a minha maturação intelectual. Gostaria de agradecer ao Lucas Petroni, pelo apoio e incentivo e a todos os colegas do departamento que sempre estiveram presentes, apoiando na minha adaptação.

Aos meus ex-professores da Universidade de Cabo Verde, em particular os Professores, Crisanto Barros, João Paulo Madeira e Daniel Costa, este por ter me apoiado com os textos e recomendações acadêmicas. Também ao prof. Dr. Claudio Furtado pelo incentivo e animo durante o meu percurso e ao Prof. Dr. José Carlos dos Anjos pela emissão da carta de recomendação no meu processo do mestrado. A Prof. Dra Roselma Évora pelas conversas e dicas que me ajudaram muito durante a escrita da dissertação. 
Agradeço de maneira especial à Prof ${ }^{a}$ Arceolinda Monteiro Ramos, a quem eu devo muito durante todo o meu percurso acadêmico. Ela tem ajudado na minha maturação intelectual desde as aulas da graduação, passando pelo projeto do mestrado e terminando nas revisões da presente dissertação. Aprendi muito com ela, com as críticas e suas exigências.

Aos meus colegas, de graduação ao mestrado em especial a Anilsa Gonçalves pela amizade construída e pelo companheirismo durante longas noites sem dormir a escrever a nossa dissertação. Agradeço aos demais colegas, Maria Filomena Semedo, Riga Borges, Albertino Ferreira, Jacinto Borges, Ivaldino Landim, pelo companheirismo e amizade construídos ao longo desses anos. A todos os meus amigos que de uma forma ou outra contribuíram, tais como: José António Landim, Higino Tavares, Assis Tavares, Jorge Sanches, Edson Moreira, Felisberto Oliveira, João Moreno, Waldir, Ricardo Jorge, Egas, Abel e ao Celso Medina pela partilha de experiências no mundo acadêmico.

Por último e não menos importante gostaria de agradecer aqui a minha namorada Maria Gorete Landim que apesar da distância sempre me apoiou e esteve por perto. Mesmo nos momentos difíceis e de aflição, ela sempre me encorajou e acreditou em mim.

Ao CNPQ através do programa do estudante convênio pós-graduação (PEC-PG) por ter financiado a minha bolsa do mestrado aqui no Brasil durante os dois anos, sem a qual este trabalho não teria sido possível. 


\section{$\underline{\text { Resumo }}$}

A presente dissertação busca entender as razões do insucesso dos pequenos partidos políticos em Cabo Verde e o seu fraco desempenho eleitoral ao longo da história política cabo verdiana. O modelo do financiamento público tem sido apontado como a causa principal deste resultado. Questionamos essa explicação, buscando mostrar que a razão que está por trás do insucesso dos pequenos partidos não se deve unicamente à dificuldade de acesso ao financiamento público, mas também a outras variáveis, nem todas elas institucionais. Através da análise dos dados do Afrobarómetro é possível inferir que os pequenos partidos não têm apoio da população. As pessoas não transferem as suas preferências numa terceira força partidária, favorecendo assim os dois grandes partidos, fomentando ainda mais o bipartidarismo.

Palavras Chaves: Financiamento Partidário Público, Financiamento Partidário Privado, Financiamento Privado, Partidos Políticos, Pequenos Partidos, Sistema Eleitoral, variáveis institucionais. 


\section{$\underline{\text { Abstract }}$}

This work seeks to understand the reasons for the failure of small political parties in Cape Verde and its weak electoral performance throughout the political history Cape Verdean . Public funding model has been suggested as the main cause of this result. We question this explanation, seeking to show that the reason behind the failure of small parties is not due solely to the difficulty of access to public funding, but also to other variables, not all of them institutional. By analyzing the Afrobarometer data we can infer that the small parties have no popular support. People do not transfer their preferences in a third party force, favoring the two major parties, encouraging even more bipartisanship.

Key words: Partisan Public Financing, Partisan Private Financing, Private Financing, Political Parties, Small Political Parties, Electoral System and Institutional Variables. 


\section{Sumário}

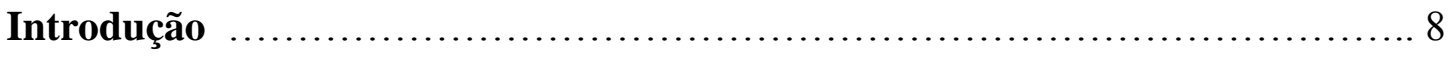

Capítulo 1 - Sistema político partidário cabo-verdiano: Da independência ao regime monopartidário........................................................... 13

1.2 - Do regime monopartidário ao multipartidarismo........................... 18

1.3 - Eleições e partidos no regime democrático cabo-verdiano......................25

Capítulo 2 - Financiamento partidário: Debates teóricos sobre o financiamento

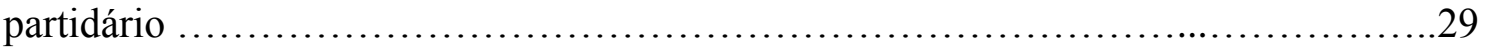

2.2 - Financiamento partidário em Cabo Verde........................................37

2.3 - Financiamento Indireto: tempo de antena.................................................51

Capítulo 3. Pequenos partidos: Sucessos/Insucessos .............................. 53

3.1 - Sistema Eleitoral cabo-verdiano..........................................53

3.2 - Preferências Eleitorais.................................................63

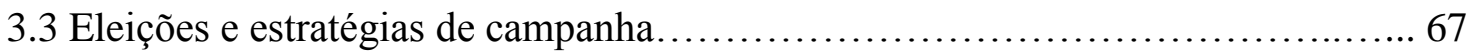

Capítulo 4 - Conclusão........................................................ 71

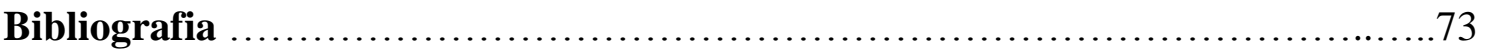




\section{Introducão}

Nos anos 90 começou o processo da transição política em Cabo Verde. Em 1991 realizaram-se as primeiras eleições multipartidárias livres, iniciando o processo da democratização do país. Inicialmente, o país viveu quinze anos sob o regime de partido único, conduzido pelo Partido Africano de Independência de Guine e Cabo Verde (PAIGC/CV), que tinha o monopólio sobre o Estado e a sociedade. A literatura tem defendido que o regime monopartidário cabo-verdiano difere dos demais estados africanos, onde se viveram situações de graves violações dos direitos civis e políticos, conforme realça Évora (2013).

Com a transição política ao regime democrático (1991), dois grandes partidos, o Movimento para a Democracia (MPD) e o Partido Africano de Independência de Cabo Verde $^{1}$ (PAICV) conquistaram toda a supremacia sobre o sistema partidário, contribuindo assim para a introdução de um sistema bipartidário. Não obstante o surgimento de forças políticas de menor porte, como a União Cabo-verdiana Independente e Democrática (UCID), o Partido da Convergência Democrática (PCD), o Partido da Renovação Democrática (PRD), o Partido Social Democrático (PSD) e o Partido do Trabalho Social (PTS), elas não foram capazes de contrastar a supremacia dos dois grandes partidos.

Desde a transição política no país, foram realizadas cinco eleições legislativas ${ }^{2}$ e cinco eleições para Presidência da República (1991, 1996, 2001, 2006 e 2011). De acordo com o art. $340^{\circ}$ do Código Eleitoral (2010) compete aos partidos políticos ou coligações de partidos políticos, apresentar candidaturas à eleição dos deputados à Assembleia Nacional e dos titulares dos órgãos municipais. Porém, o art. $341^{\circ}$ ressalva as candidaturas independentes, que podem integrar cidadãos não inscritos em partidos políticos, desde que como tal declarados.

Já para a eleição do Presidente da Republica, são candidaturas uninominais, votando-se num candidato não na bancada do partido. Assim como consagra o art. $376^{\circ}$ "As

\footnotetext{
${ }^{1}$ O PAICV surgiu fruto de uma cisão no PAIGC que ligava os dois países.

${ }^{2}$ Em Cabo Verde, não se faz a eleição para o executivo. Este é formado apartir dos resultados das eleições legislativas. $O$ partido que conseguir maior numero de assentos parlamentares é convidado a formar o governo. Sendo assim, realizam-se apenas três eleições, as legislativas, as presidências e as autarquicas (prefeitura).
} 
candidaturas para Presidente da República são propostas por um mínimo de mil e um máximo de quatro mil cidadãos eleitores e devem ser apresentadas no Tribunal Constitucional até sessenta dias antes da data marcada para as eleições".

Apesar de a democracia cabo-verdiana ser jovem, ela vem sendo apresentada como exemplo a seguir no contexto africano, visto que é uma das poucas democracias que não retornou ao regime de partido único nem passou por grandes instabilidades que colocariam em causa a sua funcionalidade.

Como reforça uma das mais importantes cientistas políticas em Cabo Verde, Évora (2013: 244), "Para a literatura, Cabo Verde cumpriu já os requisitos necessários para ser considerado um caso de transição completa e um exemplo de democracia consolidada". Assim nos termos de outro pesquisador,

“...A democracia Cabo-verdiana tem sido comumente, retratada como sendo exemplar, senão mesmo excecional no contexto africano. Após uma transição negociada entre as elites políticas do Governo e da oposição, o país tem experimentado um processo de democratização pautado por alternância política, expansão crescente de direitos políticos e liberdades civis e eleições regulares, que são avaliadas como livres e justas e são aceites como legítimas pelos principais partidos políticos. Do ponto de visto dos resultados de governação, o país tem registrado taxas de desenvolvimento económico e de desenvolvimento humanas bastante positivas que, recentemente, colocaram o país no grupo de países com desenvolvimento médio". (Sanches, 2013:250)

O país é classificado pela Freedom House $e^{3}$ como sendo livre, respeitando os direitos civis e políticos consagrados na constituição. Em geral as eleições são consideradas livres e justas por vários observadores internacionais.

Analisando o resultado da quinta rodada de pesquisa de opiniões realizada pelo Afrobarometer ${ }^{4}$, encontramos respostas que nos permitem afirmar que Cabo verde é exemplo de consolidação democrática na África. Nota-se que a maioria das pessoas (51\%) classificou a última eleição legislativa (2011) como sendo livre e justa. Do total dos respondentes, $87 \%$ entendem que devemos escolher os nossos dirigentes por meio de eleições regulares, abertas e honestas. Em Moçambique, por exemplo, apenas $75 \%$

\footnotetext{
${ }^{3}$ https://freedomhouse.org.

${ }^{4}$ http://www.afrobarometer.org/files/documents/summary results/cve r5 sor.pdf, acessado em 03.01.2015.
} 
das pessoas apoiam a escolha dos dirigentes através das eleições livres e justas. Podemos encarar esses dados e fatos como indícios de certo grau de consolidação democrática em Cabo Verde.

O gráfico abaixo apresenta o resultado de uma das perguntas da quinta rodada das entrevistas do Afrobarometro. Os dados são comparativos entre Cabo Verde e cinco países africanos.

\section{Gráfico 1- preferências por democracia.}

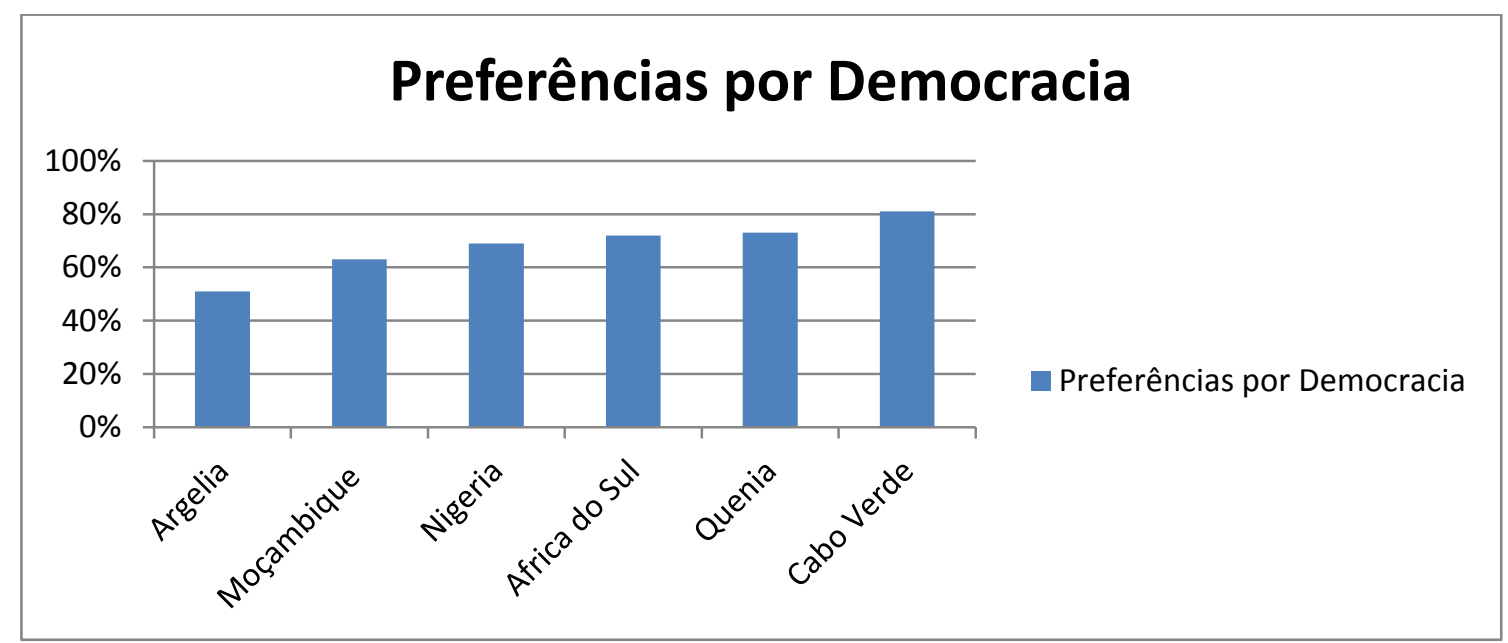

Fonte: Elaborado a partir de base dados Afrobarometer ${ }^{5}$.

Os dados mostram claramente que a percentagem de pessoas que preferem a democracia acima de qualquer outro tipo de governo é mais alta no caso cabo verdiano, comparando com os demais países em análise. Observa-se que $81 \%$ dos respondentes aprovam a democracia acima de qualquer outro tipo de governo, rejeitando o partido único. As pessoas apoiam a democracia e estão satisfeitas. Entretanto, em alguns países africanos a percentagem de pessoas que preferem a democracia acima de qualquer tipo de governo é bem menor, como no caso de Argélia (51\%), Moçambique (63\%), Nigéria (69\%), África do Sul (72\%) e Quênia (73\%).

Apesar de as pessoas preferiram a democracia acima de qualquer outro tipo de governo, os pequenos partidos não tiveram muita representatividade. Com a transição política surgiram várias forças partidárias lutando para conseguir votos e ter

\footnotetext{
${ }^{5}$ http://www.afrobarometer.org/files/documents/summary results/cve r5 sor.pdf, acessado em 03.01.2015.
} 
representações no parlamento cabo-verdiano. Porém, os pequenos partidos não tiveram sucesso ao longo das cinco eleições legislativas realizadas até agora no país. O nosso objetivo principal é entender a causa do insucesso ${ }^{6}$ dos pequenos partidos em Cabo Verde, tomando como panorama as eleições legislativas. A escolha das eleições legislativas para fazermos a análise se deve ao fato de as legislativas serem mais relevantes, tendo em conta que é a partir do legislativo que se forma o executivo e pela própria importância do legislativo no sistema político cabo-verdiano.

Organizamos a dissertação em quatro capítulos. No primeiro capítulo, debruçaremos sobre o sistema político-partidário cabo-verdiano, apresentando a trajetória que culminou no processo da independência de Cabo Verde em 1975. Analisamos a formação e os motivos que levaram o PAIGC a ter sucesso nas lutas, que desencadearam na independência política de Cabo Verde e da Guiné-Bissau. Com a instauração do regime de partido único pós-independência, procuramos entender o motivo da queda do regime e os processos que levaram à transição política e à realização das primeiras eleições livres, sob-regime multipartidário em 1991.

No segundo capítulo apresentaremos uma discussão mais geral sobre o financiamento partidário. Num segundo momento analisamos os sistemas legais de financiamento partidário nos Países Africanos de Língua Oficial Portuguesa (PALOP). Por último, vamos focar no caso de Cabo Verde, tentando entender as legislações existentes sobre o financiamento partidário, analisando também as contas e os gastos eleitorais. Existem umas discussões amplamente partilhadas pelos pequenos partidos e alguns estudiosos de que seria o financiamento partidário a principal causa do insucesso eleitoral dos pequenos partidos. De acordo com Costa (2001), o Estado é apontado como gerador de grandes desproporções na distribuição dos recursos financeiros, particularmente para os pequenos partidos.

O terceiro capítulo é destinado à discussão dos resultados e das outras hipóteses que consideramos ser pertinentes para explicar o insucesso dos pequenos partidos políticos em Cabo Verde. Aqui apresentamos o sistema eleitoral cabo verdiano, discutimos sua proporcionalidade, utilizando o método D’Hondt para transformar votos em mandatos. Embora a literatura defenda que o sistema proporcional tenderia a formar

\footnotetext{
${ }^{6} \mathrm{O}$ termo insucesso se destina aos pequenos partidos que não conseguem cadeiras significativas que Ihes permitem ter o poder de decisão no parlamento Cabo-verdiano como também para os poucos casos em que estas siglas obtêm alguma cadeira.
} 
um quadro multipartidário, em Cabo Verde se verifica o contrário já que apenas dois partidos se revezam no poder. Em particular, observar-se-á que isso se deve, em parte, à baixa magnitude média, próxima a quatro que contribui para a concentração eleitoral e parlamentar nos partidos grandes e para uma relativa desproporção na distribuição de cadeiras parlamentares entre os partidos de porte pequeno, assim como realça Costa (2001). Por fim, examinamos as preferências eleitorais a partir das quatro rodadas da pesquisa de opinião realizada pela Afrobarometro para observar qual o grau de satisfação da população com relação aos partidos cabo-verdianos. No último capítulo se destina a conclusão, em que mesmo encontrando variáveis institucionais que podem explicar o insucesso dos pequenos partidos, é também verdade que eles não conseguem penetrar na sociedade civil. Ou seja, vistos a partir da perspectiva da relação com os potenciais eleitores, há indícios de que estes últimos sentem representados pelas forças políticas de maior porte. 


\section{Capítulo 1}

\section{O Sistema Político-Partidário Cabo-Verdiano}

\subsection{Da Independência ao Regime Monopartidário.}

A independência de Cabo Verde foi proclamada no dia 5 de Julho de 1975 sendo conduzida pelo Partido Africano de Independência de Guiné e Cabo Verde - PAIGC liderado pelo seu líder Amílcar $\mathrm{Cabral}^{7}$.

Apesar da extrema importância do PAIGC na luta de independência nacional, Almada (2011) apresenta também a importância da revolução de 25 de Abril que provocou a queda do regime então vigente em Portugal, e, por conseguinte, o reconhecimento da impossibilidade da manutenção da supremacia contra os movimentos de libertação nas antigas colônias.

"Perante os sucessos militares, políticos e diplomáticos alcançados pelo PAIGC, granjeando no forte apoio da comunidade internacional e da Organização das Nações Unidas (ONU) e na sequência da queda do regime fascista português, Portugal via-se pressionado a reconhecer a independência das suas colônias" (ANDRADE, 1977; 1980 Apud. COSTA, 2001:14) ${ }^{8}$.

Com a revolução de 25 de abril de 1974 (em Portugal), e logo após a independência da Guiné-Bissau em setembro do mesmo ano, os representantes do governo português encetaram conversações com os representantes do PAIGC, no sentido de se constituir um governo de transição que visava criar as condições para a independência de Cabo Verde.

\footnotetext{
${ }^{7}$ Este partido havido sido fundado, em 1956, por Amílcar Cabral que na época o liderou, inclusive do ponto de vista militar. Para maiores detalhes sobre a figura deste líder político ver: Franco (2009); LARANJEIROCatarina2014,(disponível:http://alice.ces.uc.pt/en/wpcontent/uploads/2014/03/Mestres_d o_Mundo_Amilcar_Cabral2.pdf.).

${ }^{8}$ Interessante notar que a luta de libertação pela independência da Guiné e de Cabo Verde ocorreu no território guineense. De fato, sendo Cabo Verde um território insular e sem condições físicas que possibilitasse qualquer ofensiva militar, a luta pela independência nacional se restringiu ao território da Guiné-Bissau, participando os cabo-verdianos militarmente na ofensiva naquele país
} 
Para além do PAIGC, existiam também outras forças políticas conhecidas que lutaram pela independência, tais como a UDC (União democrática Cabo-verdiana) e a UPICV (União dos povos das ilhas de Cabo verde). Essas forças tentaram influenciar os acontecimentos, conquistar a adesão da população e ocupar o seu espaço no seio da sociedade cabo-verdiana (Almada, 2011). Santos (2013) afirma que cada um destes movimentos tentava divulgar suas ideias, embora o PAIGC estivesse numa posição hegemônica e privilegiada, visto que contava com a ajuda do Movimento das Forças Armadas (MFA), em Portugal.

O Movimento das Forças Armadas (MFA) foi um movimento surgido dentro das forças armadas portuguesas, com uma raiz golpista no intuito de derrubar o governo (Carvalho, 2009). Esse movimento veio a se organizar e angariou apoios que protagonizou no golpe do estado em 25 de Abril de 1974. Contando com o apoio massivo das pessoas, tinha como ideal democratizar o país, começando pela descolonização. Em consequência disso, os movimentos de libertação nacional ganharam força porque sentiram que podiam contar com a preciosa colaboração dos MFA, visto que a colonização ia contra os objetivos do próprio Movimento das Forças Armadas. Woollacott realçou que "o golpe 25 de Abril ergue-se como a principal linha divisória na formação do Portugal Contemporâneo, isto porque marca irreversivelmente o fim da presença colonial portuguesa em África" (Woollacott, 1983: 1131). De acordo com esse autor, na visão das lideranças do MFA, seria impossível implantar um regime democrático em Portugal enquanto se mantivesse qualquer espécie de relação colonial com África, tendo como lema "uma nação jamais poderá ser livre enquanto escravizar outra" (idem, 1983:1145). Fato é que o MFA reconheceu o PAIGC como o único legítimo representante do povo cabo-verdiano.

Na época, o programa do PAIGC tinha os seguintes objetivos declarados: "1Independência imediata e total da Guiné e de Cabo Verde; 2- Unidade da Nação na Guiné e em Cabo Verde; 3- Unidade dos povos da Guiné e de Cabo Verde; 4- Unidade Africana; 5- Regime democrático, anti-colonialista e anti-imperialista; 6- Independência econômica, estruturação da economia e desenvolvimento da produção; 7- Justiça e progresso para todos; 8- Defesa nacional eficaz e ligada ao povo; 9- Política internacional própria, no interesse da Nação, da África, da paz e do progresso da humanidade.” (Programa do PAIGC, In Lopes 1996:33; apud. Évora, 2001: 38). 
De acordo com Évora (2001), a independência de Cabo Verde só foi possível graças à luta armada desencadeada no território guineense. A 20 de Janeiro de 1973, o PAIGC sofreu um golpe duro com o assassinato de Amílcar Cabral em Conakry. Porém, após a morte de Cabral a luta continuou e Portugal se sentia cada vez mais pressionado em reconhecer as independências das suas colônias (Angola, Moçambique, São Tomé e Príncipe, Guiné-Bissau e Cabo Verde). Com os sucessos da luta armada orquestrados pelo PAIGC, a Guiné-Bissau conseguiu a sua independência dois anos antes de Cabo Verde. Em 14 de Outubro de 1972, os membros do PAIGC organizaram uma assembleia constituinte na Guiné-Bissau onde somente o PAIGC apresentou as candidaturas. O resultado era o esperado, visto que $97,13 \%{ }^{9}$ das pessoas votaram no "sim" legitimando o partido, elegendo os membros que viriam a compor o governo pósindependente. Com essa aprovação das pessoas o partido veio a proclamar a independência de Guiné-Bissau a 24 de Setembro de 1973.

Com a independência da Guiné-Bissau a luta continuou pela independência de Cabo Verde. No entanto, Portugal não queria abrir mão de Cabo Verde, tendo sugerido até a realização de um referendo para saber se a população queria ser livre ou ficar ligada a Portugal, assim como realça Amada (2011). A semelhança do que tinha acontecido em Guiné-Bissau, a 30 de Junho de 1975, o PAIGC organizou uma eleição, aonde $95,58 \%{ }^{10}$ das pessoas votaram "sim", aprovando e legitimando as ações do partido. Dessa eleição saiu uma assembleia constituinte que veio a proclamar a independência de Cabo Verde a cinco de Julho do mesmo ano e promulgou a Lei da Organização Política do Estado (LOPE) ${ }^{11}$ vigorando de 1975-1980, fazendo às vezes da constituição, que só viria a ser aprovada na IX sessão legislativa de cinco de setembro de 1980. (Costa, 2001).

Após a independência surgiram novas forças partidárias. A união Cabo-verdiana Independente e Democrática (UCID) surgiu a 13 de Maio de 1978 no seio de um grupo de cidadãos cabo-verdianos residentes na Holanda, descontentes com o projeto da unidade da Guiné e Cabo Verde. Este era um partido clandestino porque o PAIGC se

\footnotetext{
${ }^{9}$ http://africanelections.tripod.com/gw.html, acessado em 11.11.2014

10 http://africanelections.tripod.com/cv.html\#1975 Constituent Assembly Election, acessado em 11.11.2014
} 
tornou o único partido legitimo a governar o país e a participar das eleições. Sendo assim, a UCID só conseguiu legalizar sua posição como partido depois das primeiras eleições multipartidárias, em junho de $1991 .{ }^{12}$ A lei da Organização Política do Estado (LOPE) aprovada logo após a independência reconhecia de fato o PAIGC como única força dirigente da sociedade cabo-verdiana.

A soberania do Povo de Cabo verde é exercida no interesse das massas populares, as quais estão estreitamente ligadas ao Partido Africano da Independência da Guiné e Cabo Verde (PAIGC), que é a força política dirigente na nossa sociedade. (art. $1^{\circ}$, da LOPE, 1975)

Assim como já referido o PAIGC tinha como objetivo principal a unidade dos dois países. Entretanto esse objetivo não se realizou por causa de alguns fatores, em, sobretudo, do golpe de estado em Guiné-Bissau orquestrado por Nino Vieira, acabando assim com o sonho de Cabral, que era o da união dos dois países. Esse golpe é entendido como sendo o principal motivo da separação dos dois países e da cisão do partido, tendo o ramo de Cabo Verde do PAIGC optado por criar um novo partido, o "PAICV" 13 .

Cabo Verde aprovou a sua primeira constituição na IX sessão legislativa, em 5 de Setembro de 1980. A constituição veio consagrar no seu $4^{\circ}$ art. o seguinte:

1. Na República de Cabo Verde, o partido Africano da Independência da Guiné e Cabo Verde (PAIGC) é a força política dirigente da sociedade e do Estado. (art. $4^{\circ} \mathrm{CRCV}^{14} .1980$ )

2. No desempenho da sua missão histórica, o PAIGC exerce seu papel dirigente na base da presente constituição, cabendo-lhe designadamente: estabelecer as bases gerais do programa político, económico, social, cultural, de defesa e segurança a realizar pelo estado; definir as etapas da reconstrução nacional e estabelecer as vias da sua realização. (art.4 $4^{\circ}$, idem).

Durante o regime do partido único realizaram-se três eleições legislativas (em junho 1975 , dezembro 1980 , e dezembro, 1985) ${ }^{15}$ sem a presença de outras forças

\footnotetext{
${ }^{12}$ Entrevista feita a Presidente da UCID (António Monteiro) por Arceolinda Ramos, em Setembro de 2011.

${ }^{13}$ Partido Africano de Independência de Guine e Cabo Verde. Partido cujos fundadores foram os que lutaram pela independência nacional de Cabo Verde.

${ }^{14}$ A sigla CRCV, corresponde a Constituição da Republica de Cabo Verde.
} 
políticas, além dos candidatos do PAIGC. Nesta época, apesar do monopólio partidário, há fortes evidências de tensões dentro do PAIGC e os demais partidos que mesmo não representados, defendiam outras causas.

Com o assalto ao Radio Barlavento que aconteceu entre o período após golpe 25 de Abril e a proclamação da independência nacional, o regime adotou medidas repressivas contra as já reduzidas formas de livre expressão existentes no país. Assim como Santos (2013) nos diz,

"o assalto àquela estação emissora privada proporcionou ao PAIGC o ensejo e controlar os poucos meios de comunicação social e de se afirmar como único produtor de ideias no emergente mercado político, não dando assim quaisquer possibilidades a outros sectores da sociedade caboverdiana para se fazerem ouvir, matando, passe o termo, à nascença o pluralismo a instituir, décadas depois do Estado Novo"(Santos, 2013:216).

De acordo com Santos (2013), o PAIGC já contava com o apoio do MFA para adquirir o monopólio do Estado e obstruir todas as atividades da UDC e UPICV. Isso ficou visível com a prisão de setenta políticos da UDC e UPICV, entre 14 e 16 de Dezembro de 1974. Muitos estudiosos entendem que essas prisões podem ser consideradas como sendo um dos motivos que impediram a implantação da democracia logo após a independência nacional. "De modo oposto, o secretario geral da UPICV recorda que desde o período da luta armada na Guiné, o PAIGC sempre procurou eliminar "as eventuais formações políticas rivais" tal como aconteceu em Cabo Verde depois da Revolução de Abril” (Santos, 2013:218).

Aprovando a lei LOPE, que legitima e reconhece o partido como única força dirigente, os pequenos partidos não tinham quaisquer chances de organizar-se legalmente. Portanto, é evidente que o PAIGC acabou desde cedo com as esperanças de outros partidos existentes quando decidiu constitucionalizar a sua supremacia. Em consequência disso "a reinstalação do autoritarismo produziu um sistema político de governo por detrás do qual se achava um partido único, no caso vertente o PAIGC/CV,

15 http://africanelections.tripod.com/cv.html\#1975 Constituent_Assembly Election, acessado em 11.11.2014. 
que se proclamava, à luz da LOPE, e da constituição de 1980, como força dirigente da sociedade e do Estado”. (Santos, 2013:223). A cientista política Évora (2013) realça o seguinte:

\begin{abstract}
"Seguindo a tendência dos outros países africanos, Cabo Verde adota após independência política um regime autoritário monopartidário. Entretanto, o regime autoritário Cabo-verdiano deve ser compreendido levando em atenção algumas dimensões particulares. O primeiro aspecto diz respeito ao nível de moderação do regime autoritário monopartidário. O regime autoritário Caboverdiano foi muito mais moderado em termos de repressão e violação dos direitos humanos quando comparado aos restantes regimes de partido único africano (Cahen, 1991:114). Um segundo aspecto está ligado à escolha por um regime monopartidário com clara orientação socialista. Essa escolha contribuiu segundo (chabal, 1995), para uma orientação de políticas públicas com forte investimento do governo em áreas sociais (educação e saúde). Essa orientação veio a garantir nos anos seguintes independência ao reforço da coesão social, já existente em Cabo Verde, e impediu, por outro lado, que se formasse um sistema neopatrimonial que se tornou comum em muitos países africanos no período pós-independência”. (Évora, 2013:235).
\end{abstract}

\title{
1.2 Do Regime Monopartidário ao Regime Multipartidário
}

Entre 1975-1985, a Assembleia Nacional Popular era constituída apenas por deputados do PAIGC/CV, único partido com poder e legitimidade para apresentar candidatos. Entretanto na última legislatura (1985/90) antes da abertura política tinha candidatos independentes eleitos nas listas do PAIGC/CV. Era uma supremacia do partido único no sistema político. A implantação de um regime do partido único era justificada em razão da legitimidade histórica do partido político - o PAICV, que se proclama o responsável por salvaguardar a identidade cabo-verdiana.

As razões da abertura política e a decisão de transitar para a democracia têm diferentes interpretações. Correia e Silva (1997: 3-7) citado por Évora, (2001) destaca as razões econômicas como importantes para a abertura política. $\mathrm{O}$ autor salienta ainda que, com a abertura econômica, as pressões aumentaram, possibilitando assim criar condições para abolir o regime do partido único. 
Entretanto, de acordo com esta autora (2001), as razões econômicas influenciaram o processo de abertura política em Cabo Verde, mas não foram determinantes para a mudança política. A autora defende que houve uma combinação de fatores políticos e econômicos que levou à falência do regime do partido único. Sobretudo, os dirigentes do partido único iniciaram o processo de transição em função do surgimento de uma nova força política, o Movimento para a Democracia (MPD), que veio dar um novo rumo ao processo de reforma política. O Movimento para a Democracia surgiu em Março de 1990 e era constituído por antigos membros do partido único que estavam descontentes e passaram a defender a democracia. Assim, a democratização deve ser entendida como um esforço conjunto da oposição e dos líderes do regime autoritário.

Alguns autores ainda defendem que o processo da transição está na base do descontentamento da própria população. Assim, por exemplo, os estudantes, muitos dos quais viviam em países democráticos, tiveram papel importante. Por conta dessa vivência sentiam-se inquietos com a situação no país de origem, com isso começaram a mobilizar forças e apoios ao processo da democratização. Almada realça o seguinte:

"Por outro lado, os estudantes Cabo-verdianos que, já em número razoável, frequentavam os estabelecimentos de ensino no exterior (particularmente na Europa), bem como os quadros técnicos e superiores regressados, em número significativo das universidades estrangeiras durante todos os anos oitenta do século $\mathrm{XX}$, iam tomando pulso às modificações democráticas em curso e, também eles eram portadores dessa sede e vontade de mudança para o seu País”. Almada (2011: 77)

A essa altura, foram abertos os canais de negociação com a oposição (MPD) e foram aprovadas várias leis importantes para a organização do processo de transição que decorreu de forma rápida e relativamente tranquila sem maiores tropeços. (Costa, 2001; Lima, 1992). Costa nos apresenta um conjunto das questões que foram discutidos:

“a) proposta de lei de revisão constitucional; b) proposta de lei para as eleições legislativas; c) proposta de lei dos partidos políticos; d) o calendário da transição e) a presença de observadores internacionais para as eleições legislativas marcadas para 13 de janeiro de 1991. Como fruto das negociações conseguiu-se, Nomeadamente, o seguinte: 1) o acordo sobre a eleição directa do presidente da República para 17 de fevereiro de 1991; 2) a determinação da 
sequência dos dois atos eleitorais, tendo prevalecido à posição do MPD de que as eleições legislativas deveriam ser realizadas em primeiro lugar; 3) o acordo sobre o número dos deputados da emigração, em que o MPD pediria seis deputados e o PAICV três, tendo-se optado na mesa das negociações por esta última posição; 4) o entendimento sobre os requisitos para a constituição de partidos políticos e a interdição de determinados tipos designação para os partidos e 5) o acordo quanto à postura de neutralidade por parte da administração local de transição" (Costa, 2001:17-18).

Perante esse cenário da transição algumas instituições formais foram criadas. Alterou-se a constituição da República de Cabo Verde, instituiu-se o regime jurídico dos Partidos Políticos, alterou-se a lei eleitoral para Assembleia Nacional e institui-se o tempo de antena na radio e na televisão e a resposta política no parlamento. Algum mecanismo especifica da revisão constitucional de 1990 contribuíram para o processo da democratização do País. A constituição até então vigente havia sido aprovada em 1980, baseando-se nos objetivos do próprio partido do poder. A lei n $2 / \mathrm{III} / 90^{16}$ alterou a constituição da República de Cabo Verde num sentido mais democrático. Em particular, um dos aspectos mais importantes que esteve presente na revisão constitucional é a queda do artigo $4^{\circ}$ que consagra o PAICV como única força dirigente da sociedade e do estado, que passou a ter seguinte redação:

É livre a constituição de partidos políticos.

Os partidos políticos concorrem para a organização e expressão da vontade popular e do pluralismo político e constituem estrutura mediadora fundamental da participação dos cidadãos na vida pública.

É interdita a constituição de partidos de âmbito regional ou local, de partidos que fomentem o regionalismo ou o racismo, ou se proponham empregar meios subversivos ou violentos na prossecução dos seus fins. (art. $4^{\circ}$ Lei Constitucional 1990.)

A lei $\mathrm{n}^{\circ} 86 / \mathrm{III} / 90^{17}$ consagrou o regime jurídico dos partidos políticos e que, como veremos mais adiante, trata também do sistema de financiamento dos partidos políticos. Iremos explorar alguns artigos da referida lei. Em primeiro lugar, observa-se o caráter democrático que se atribui ao partido. De acordo com a lei:

\footnotetext{
${ }^{16}$ In Boletim Oficial no39 de 29 de Setembro de 1990, Suplemento.

${ }^{17}$ Boletim Oficial nㄴ40, de 6 de Outubro de 1990, Suplemento.
} 
"Partidos Políticos são associações de cidadãos que, com caráter de permanência, autonomia e consistência de organização, concorrem livremente para a formação e a expressão da vontade política, de acordo com a constituição, e os seus estatutos e programas publicados, visam participar na representação do povo na Assembleia Nacional Popular ou nas assembleias e demais órgãos eletivos das autarquias locais" $\left(\right.$ art. $\left.1^{\circ}, \mathrm{RJPP}^{18}\right)$.

Interessante a este propósito a ideia de que o partido tenha que ter certa penetração no território. Diz à lei que é proibida a constituição de partidos de caráter regional ou local, de acordo com o segundo artigo do regime jurídico dos partidos políticos.

"É proibida à constituição de partidos de caráter e âmbito regional ou local, e partidos que fomentem o regionalismo ou o racismo ou proponham meios subversivo ou violento na prossecução dos seus fins" (art.2 $\left.{ }^{\circ}, \mathrm{RJPP}\right)$.

Do ponto de vista da criação de novas forças políticas a legislação não apresenta muitos empecilhos. Um dos aspectos importantes, durante o processo da transição foi de fato os mecanismos legais para legalização de um determinado partido político. $\mathrm{O}$ artigo $6^{\circ}$ do regime dos partidos políticos informa a respeito das condições impostas aos partidos políticos para sua organização, durante o período de transição democrática.

“A inscrição é feita a requerimento, no mínimo de 500 cidadãos maiores de 18 anos, em pleno gozo dos seus direitos políticos e civis. Entre os requerentes figurarão pelo menos 10 residentes em cada um dos nove dos 14 concelhos do país" (art.6 $\left.6^{\circ}, \mathrm{RJPP}\right)$

"O requerimento de inscrição é dirigido ao Presidente do Supremo Tribunal de Justiça e será acompanhado de: a) Relação nominal dos requerentes com a indicação dos respectivos locais de residência; b) Documento comprovativo da capacidade eleitoral dos cidadãos requerentes; c) Projetos de estatutos e programa; d) Projeto de denominação, sigla e símbolos dos partidos; e) Declaração dos requerentes de que aceitam os estatutos e o programa do partido". (art. $6^{\circ}$, idem).

\footnotetext{
${ }^{18}$ Regime Jurídico dos partidos politicos.
} 
Argumentados que esse requisito seja a primeira barreira institucional que condicionou a criação e o crescimento dos pequenos partidos ${ }^{19}$. Tendo em conta a rapide ${ }^{20}$ do processo, não havia como os líderes da UCID organizarem-se no território e conseguirem assinaturas das 500 pessoas em pleno gozo dos seus direitos políticos e civis. Isso vai à mesma linha que defende Sanches (2013). De acordo com esta autora, o fato da lei dos partidos ter sido publicada poucos meses antes das eleições legislativas, adotando normas específicas para o registro e organização dos partidos, acabou por condicionar a participação das forças políticas menores.

Importante aspecto da referida lei é o que diz respeito ao mecanismo de financiamento dos partidos políticos. $\mathrm{O}$ artigo $18^{\circ}$ expõe os mecanismos legais de financiamento, e o artigo $21^{\circ}$ apresenta os que são considerados como sendo proibidos. Assim sendo,

"A atividade dos partidos políticos é financiada essencialmente por: As Contribuições gerais ou quotas dos membros; Contribuições especiais dos titulares de cargos políticos estatais remunerados; Rendimento dos bens e atividade próprios; Doações; Créditos; Subsídio anual atribuído aos partidos representados na Assembleia Nacional Popular" (art. 18 RJPP).

"É vedado aos organismos autónomos do Estado, associações de direito público, institutos e empresas públicas, autarquias locais e pessoas coletivas de utilidade pública administrativa financiar ou subsidiar os partidos políticos" (art.21 ${ }^{\circ}$, idem).

Interessante é a norma prevista pelo artigo $23^{\circ}$ da lei que prevê um conjunto de benefícios e isenções, destinado aos partidos políticos que obtiveram pelo menos 5\% dos votos validamente expressos nas eleições legislativas.

\footnotetext{
${ }^{19}$ Apesar de essa exigência parecer modesta em comparação a outros países, no caso Cabo-verdiano consideramos ser uma barreira para um partido que não tenha qualquer legado a qual se identificava na época. Isso porque, o PAICV se identificava como partido que lutou pela independência nacional e o MPD era visto como partido da esperança, que iria levar o país a democracia. Acreditamos que essa exigência foi expressiva tendo em conta que na ultima eleição realizada ainda no período partido único (1985) estavam registado 98.692 eleitores, eram desses eleitores que os pequenos partidos tinham que conseguir 500 assinaturas. Entretanto após o processo de negociação para a transição política, com atualização do recenseamento eleitoral registaram 166.818 eleitores. Nota-se que a UCID só conseguiu registrar e legalizar como partido após as primeiras eleições legislativas, altura em que se verifica um aumento de numero de eleitores.

20 Entendemos essa rapidez no distanciamento entre a aprovação das legislações eleitorais e a realização das primeiras eleições legislativas livres.
} 
“Contribuição predial pelos rendimentos coletáveis de prédios ou parte de prédios urbanos de sua propriedade onde encontrem instalados a sede central, delegações e serviços; Sisa pela aquisição dos edifícios necessários à instalação da sua sede, delegações e serviços e pelas transmissões resultantes de fusão ou cisão; Imposto do Selo; Imposto sobre as sucessões e doações; Preparos e custas judiciais" (art. 23ㄹ, idem).

Portanto, a lei $\mathrm{n}^{\circ} 87 / \mathrm{III} / 90^{21}$ alterou a lei eleitoral da Assembleia Nacional Popular, tendo em conta que a lei eleitoral até então vigente foi aprovada no período do partido único. É mais do que evidente que a nova lei eleitoral passou a ter alguns dispositivos que podem ser vistos como sendo democráticos. Para além das medidas acima comentadas, importante é observar que o art. $17^{\circ}$ da lei eleitoral para a Assembleia Nacional adota o método de representação proporcional de Hond't. (art. $17^{\circ}$ lei eleitoral 1990.) e o direito a tempo de antena nas emissões de Radio e televisão de forma gratuita e mensalmente. Inclusive a própria lei no artigo $12^{\circ}$, consagrava que "aos partidos políticos da oposição serão atribuídos o direito de resposta política às declarações políticas do Governo proferidas nas emissões da Rádio Nacional de Cabo Verde e da Televisão Nacional de Cabo Verde".

Cremos que as leis aprovadas desde a transição política não levaram em questão as pequenas forças partidárias. Acreditamos que as leis foram feitas para servir os dois partidos que se tornariam hegemônicos (MPD e PAICV). Os dois partidos que participaram no processo da transição política legislaram de acordo com seus interesses e objetivos. Isso vai à mesma linha que defende Sanches (2013:263), “sendo o MPD e PAICV os principais arquitetos do processo de transição também conseguiram delinear o calendário de mudança e adotar as medidas que lhes eram mais favoráveis". Dada à lei dos partidos políticos introduzida em Cabo Verde em outubro de 1990, e tendo em conta que as primeiras eleições realizaram-se em 1991, “os partidos políticos dispuseram de pouco mais de dois meses para se constituírem legalmente e competirem eleitoralmente". (Sanches, 2013:263). Entende-se que a aprovação desse regime jurídico dos partidos políticos podia ser um dos momentos em que os pequenos partidos poderiam entrar na agenda. Porém, apenas os dois grandes partidos tiveram tempo suficiente e canais institucionais para veicularem os seus interesses. A UCID veio tarde

\footnotetext{
${ }^{21}$ Boletim Oficial no41, de 13 de Outubro de 1990, 2o Suplemento.
} 
para se instalar em Cabo Verde e acabou por ficar sem peso nos debates, mesmo mais tarde, por falta de número suficiente de deputados. Assim como realça Sanches (2013: 268) "A lei dos partidos, publicada poucos meses antes das primeiras eleições incorporava muitos requisitos para o registo e formação dos partidos e condicionou a participação eleitoral de outras forças políticas que operam fora do território nacional".

A tabela a seguir sintetiza as diferentes fases de evolução do sistema político caboverdiano, até a democracia atual, instaurada em 1991.

Tabela 1. Sistema Político Partidário Cabo-verdiano. (1975-2013)

\begin{tabular}{|c|c|c|c|c|}
\hline Período & $\begin{array}{l}\text { Regime } \\
\text { Político }\end{array}$ & $\begin{array}{l}\text { Sistema } \\
\text { partidário }\end{array}$ & $\begin{array}{l}\text { Sistema } \\
\text { eleitoral }\end{array}$ & $\begin{array}{l}\text { Sistema de } \\
\text { governo }\end{array}$ \\
\hline Até 1975 & $\begin{array}{l}\text { Colônia de } \\
\text { Portugal }\end{array}$ & Inexistente & Inexistente & Inexistente \\
\hline 1975-1991 & Autoritário & Monopartidário & Proporcional & Parlamentar \\
\hline $\begin{array}{l}\text { 1991- } \\
\text { presente }\end{array}$ & Democrático & Multipartidário & $\begin{array}{l}\text { Proporcional, } \\
\text { utilizando o } \\
\text { método } \\
D^{\prime} \text { Hont }\end{array}$ & $\begin{array}{l}\text { Forma de } \\
\text { governo: semi- } \\
\text { presidencial }\end{array}$ \\
\hline
\end{tabular}

Fonte: Elaboração própria, a partir das leis constitucionais.

Assim como realçou Évora (2009), "Cabo Verde é apontado como exemplo por ter feito desde então uma trajetória diferente do que aconteceu majoritariamente no cenário africano. Desde que implantou o regime democrático, o país não conheceu nenhum episódio de instabilidade política". Sanches (2013) realça que Cabo Verde é atualmente uma das democracias que melhor funciona quer por comparação a outras democracias africanas quer por comparação a democracias de primeira e segunda vaga. De acordo com o Economist Intelligent Unit's Index de 2012 ${ }^{22}$, Cabo Verde é a segunda melhor democracia em África, depois Maurícias $\left(18^{\circ}\right)$, ocupando o mesmo lugar que Portugal $\left(26^{\circ}\right)$ de uma lista de 167 países, e estando a frente de várias democracias antigas e mais consolidadas no contexto europeu (França $28^{\circ}$ e Itália $32^{\circ}$ ) e no contexto africano (África do Sul $31^{\circ}$ e Botswana $30^{\circ}$ ).

${ }^{22}$ The Economist Intelligence Unit's Index of Democracy 2012. 


\subsection{Eleições e Partidos no Regime Democrático Cabo-verdiano}

Desde a transição política em Cabo Verde já foram realizadas cinco eleições legislativas, nas quais os partidos concorrem em vários círculos eleitorais espalhados pelo país e na diáspora ${ }^{23}$. A tabela abaixo apresenta as cadeiras conseguidas pelos partidos políticos desde a transição política (1991) até a última eleição legislativa (2011), confirmando a forte hegemonia dos dois grandes partidos.

Tabela 2. Cadeiras elegidas, (1991-2011).

\begin{tabular}{|c|c|c|c|c|c|c|c|c|c|c|}
\hline Eleições & \multicolumn{2}{|c|}{1991} & \multicolumn{2}{|c|}{1995} & \multicolumn{2}{|c|}{2001} & \multicolumn{2}{|c|}{2006} & \multicolumn{2}{|c|}{2011} \\
\hline Partidos & Cadeiras & $\begin{array}{l}\% \\
\text { votos }\end{array}$ & Cadeiras & $\begin{array}{l}\% \\
\text { votos }\end{array}$ & Cadeiras & $\begin{array}{l}\% \\
\text { votos }\end{array}$ & Cadeiras & $\begin{array}{l}\% \\
\text { votos }\end{array}$ & Cadeiras & $\begin{array}{l}\% \\
\text { votos }\end{array}$ \\
\hline$\overline{\text { PAICV }}$ & 23 & 33.0 & 21 & 29.8 & 40 & 47.3 & 41 & 52.28 & 37 & 51 \\
\hline MPD & 56 & 67.0 & 50 & 61.3 & 30 & 39.8 & 29 & 44.02 & 33 & 41.9 \\
\hline UCID & ------ & ---- & ------- & ---- & ---- & $\begin{array}{l}--- \\
\end{array}$ & 2 & 2.64 & 2 & 4.9 \\
\hline PRD & --- & --- & ---- & ---- & ----- & 3.2 & ---- & --- & ---- & --- \\
\hline ADM & ----- & ----- & ---- & ---- & $2^{24}$ & 6.0 & --- & --- & ---- & ---- \\
\hline PCD & ---- & ---- & 1 & 6.7 & $\begin{array}{l}--- \\
\end{array}$ & 0.4 & --- & ---- & ----- & 0,4 \\
\hline PTS & ---- & ----- & ----- & ---- & ---- & --- & ---- & ---- & ----- & 0,5 \\
\hline Total & 79 & 100 & 72 & 100 & 72 & 100 & 72 & 100 & 72 & 100 \\
\hline
\end{tabular}

Fonte: Elaborado a partir dos resultados eleitorais da CNE; http://africanelections.tripod.com/cv.html (acessado em 16.11.2014); Economist Intellegent Unit's.

Na primeira eleição legislativa (1991) concorreram apenas dois partidos, o Movimento para Democracia (MPD) e o Partido Africano da Independência de Cabo Verde (PAICV). O MPD foi o partido que surgiu durante o processo a transição política tendo vencido por maioria qualifica (maioria de dois terços) as duas primeiras eleições legislativas pós-transição política. Já o PAICV, que é considerado como partido da independência perdeu as eleições em 1991 e voltou ao poder em 2001 e até o momento governa o país. No entanto, a UCID, que atualmente é a terceira força

\footnotetext{
${ }^{23}$ A diáspora refere aos círculos eleitorais no estrangeiro, aonde existe uma comunidade cabo-verdiana. ${ }^{24}$ Fruto de uma coligação (PCD, PTS e UCID) denominada, de Aliança Democrática para a Mudança (ADM).
} 
partidária, não conseguiu se legalizar a tempo de concorrer nas eleições legislativas de 13 de Janeiro de 1991, visto que só viria a se oficializar enquanto partido em junho de 1991.

Fala-se que na altura da aprovação das leis eleitorais, havia deputados que defendiam a dispensa de algumas das exigências jurídicas para que a UCID conseguisse participar nas primeiras eleições dada à data do seu surgimento (1978). Assim diz Almada;

"Na altura, e antes mesmo da discussão da proposta de Lei, houve Deputados que entenderam e defenderam que se adotasse, para o caso específico da UCID um princípio que o dispensasse dalgumas das exigências decorrentes do diploma a aprovar-se, atendendo a que esse partido já existia, de facto e reconhecidamente, desde 1978, e que o legislador não devia ignorar isso. A posição desses Deputados, porém, não foi aceite nem assumida, e por isso, não foi integrada na proposta que veio a ser discutida e aprovada. Assim, a UCID não pôde comparecer às eleições que teriam lugar em Janeiro de 1991, porque não conseguiu, na situação em que se encontrava preencher os requisitos que a lei veio a impor" (Almada, 2011:96-97).

Entretanto a maioria dos deputados não aceitou e a UCID não conseguiu reunir a tempo todos os requisitos legais para se oficializar e apresentar nas eleições legislativas de 1991.

Deve ser lembrado que, entre 1991 e 2000, o sistema de partidos registrou um número consistente de novas forças políticas, pelo menos no âmbito eleitoral. Após as eleições de 1991, surgiu o Partido Social Democrata (PSD), em virtude de uma cisão no interior da UCID. Da mesma forma, em função de uma cisão no MPD nasceu em 1993 o Partido da Convergência Democrática (PCD). E em 2000 foram criados o Partido do Trabalho e Solidariedade (PTS), por Onésimo Silveira, e o Partido da Renovação Democrática (PRD), este último produto de uma ulterior cisão do MPD. Este conjunto de pequenos partidos tem concorrido individualmente, coligando-se, apresentado as listas dos candidatos desde 1995. (Sanches, 2013). Entretanto, todas estas forças políticas, com a exceção da UCID, não conseguiram cadeiras no Parlamento. A UCID nas últimas eleições obteve apenas duas cadeiras. 
Os dados apresentados na tabela 2 mostram que apenas dois partidos políticos disputam com sucesso as eleições em Cabo Verde. Livramento (2005), um dos exdirigentes do PRD, salienta que um dos pilares da democracia reside nos partidos políticos, tidos como intermediários entre o Estado e a sociedade. Afirmou ainda, que a democracia cabo-verdiana é bipolarizada e tem levado a resultados eleitorais que dão uma maioria absoluta ao MPD ou ao PAICV. Assim os outros partidos concorrentes não conseguem eleger deputados, e, se elegem, não ultrapassam os dois deputados. A estrutura bipartidária do legislativo em Cabo Verde e as maiorias absolutas obtidas pelos dois principais partidos do país nas eleições legislativas desde 1991 têm como resultado principal a formação de governos coesos e estáveis. As maiorias parlamentares alcançadas possibilitaram aos dois maiores partidos (PAICV, MPD) levar adiante a sua agenda política e governar com tranquilidade durante seus mandatos, sem risco de perder apoio parlamentar.

Apresentando um panorama geral sobre o sistema político-partidário caboverdiano, iremos nos debruçar sobre o nosso problema de pesquisa. O que explica este insucesso das forças políticas partidárias minoritárias? Nos próximos capítulos tentaremos encontrar uma razão para a manutenção deste quadro bipolar. Muitos dirigentes dos pequenos partidos, tais como a UCID têm reclamado do atual modelo de financiamento público. António Monteiro ${ }^{25}$, atual presidente da UCID, entende que o financiamento público é injusto, sendo que a UCID é uma prova de que não se consegue desenvolver todo o trabalho político por falta de recursos. Monteiro ${ }^{26}$ apontou a escassez dos recursos financeiros e humanos como sendo a principal razão que explica o insucesso da UCID nas eleições. Isso vai à mesma lógica defendida por Ramos (2012:89):

"O mecanismo de financiamento através da subvenção estatal tem sido contestado pelos partidos que têm pouca ou nenhuma representação parlamentar e fragilizado reconhecimento da função pública dos pequenos partidos no sistema democrático".

\footnotetext{
${ }^{25}$ Entrevista realizada por mim ao Presidente da UCID via email em Julho de 2014. Eleito líder da UCID pela primeira vez no congresso de Julho de 1997. Desde então tem como próposito de criar um potencial de chantagem dentro do sistema partidário Cabo-Verdiano (Ramos, 2012:64-65). ${ }^{26}$ Idem.
} 
O próximo capítulo será dedicado ao debate em torno do financiamento público enquanto os capítulos subsequentes buscarão apresentar hipóteses alternativas que explicam o insucesso dos pequenos partidos políticos. 


\section{Capitulo 2}

\section{O Financiamento Partidário}

\subsection{Debates teóricos sobre o financiamento partidário.}

O financiamento público foi instituído na segunda metade do século $\mathrm{XX}$, como sendo uma solução perante os problemas consequentes do financiamento privado. A ideia básica era que a demanda por recursos financeiros, até então provenientes de fontes privadas com todas as implicações negativas, pudesse ser suprido por recursos públicos. O financiamento dos partidos políticos e das campanhas eleitorais é algo importante, sobretudo do ponto de vista da informação, fornecendo ao eleitor informação para exercer o seu direito de voto informadamente.

Zovato diz o seguinte:

"o financiamento público como sendo uma maneira de evitar ou diminuir a incidência de interesses particulares e poderes fáticos no desempenho das funções partidárias. Seu objetivo é, por um lado obter condições mais equitativas durante a competição eleitoral entre os diversos atores políticos e por outro lado uma maior transparência em matéria de financiamento voltada para mitigar os altos níveis de corrupção política”. (Zovato, 2005:299)

"Um argumento adicional a favor do financiamento público é que ele é concedido com a intenção de fazer com que as operações financeiras dos partidos, suas receitas e suas despesas, corram por vias transparentes, conhecidas e sujeitas aos órgãos de controle e fiscalização do erário público" (Zovato, 2005:299).

Considera ainda o autor que a história e a experiência comparada mostram que a relação entre dinheiro e política foi, é e continuará sendo complexa, e que ela constitui uma questão fundamental para a qualidade e estabilidade da democracia. Zovato, citando Sartori (1992: 197) realça que é a competição entre os partidos com recursos equilibrados, tais como políticos-humanos e econômicos que gera a democracia. 
A tabela a seguir apresenta os principais argumentos do financiamento público.

Tabela 3. Pros e contras do financiamento público.

\begin{tabular}{|c|c|}
\hline Pros & Contra \\
\hline $\begin{array}{l}\text { Fortalece a autonomia dos partidos } \\
\text { políticos e com isso ficam livres de } \\
\text { influência dos grupos econômicos }\end{array}$ & $\begin{array}{l}\text { O financiamento público não elimina as } \\
\text { outras fontes de financiamento, porque } \\
\text { nenhum governo tem a capacidade para } \\
\text { fiscalizar eficazmente as doações } \\
\text { partidárias. }\end{array}$ \\
\hline $\begin{array}{l}\text { Permite uma maior fiscalização dos } \\
\text { fundos partidários }\end{array}$ & $\begin{array}{l}\text { Quando os partidos e os candidatos } \\
\text { dependem exclusivamente das } \\
\text { subvenções dos estados, os partidos } \\
\text { ficam longe dos seus militantes e } \\
\text { simpatizantes. }\end{array}$ \\
\hline $\begin{array}{l}\text { Promove a competição partidária, uma } \\
\text { vez que garante uma renda mínima a } \\
\text { todos os partidos e candidatos. }\end{array}$ & $\begin{array}{l}\text { A excessiva dependência do } \\
\text { financiamento público coloca os partidos } \\
\text { políticos numa situação de } \\
\text { vulnerabilidade quando há uma crise nas } \\
\text { finanças publicas }\end{array}$ \\
\hline $\begin{array}{l}\text { Reduz a probabilidade de o partido } \\
\text { concorrer a fontes de financiamento } \\
\text { ilegal ou os doadores de má reputação. } \\
\text { O partido ou candidato recebe um } \\
\text { valor mínimo necessário para a sua } \\
\text { campanha }\end{array}$ & $\begin{array}{l}\text { A transparência que propicia o } \\
\text { financiamento público desincentiva a } \\
\text { maior parte do financiamento privados } \\
\text { aos partidos políticos }\end{array}$ \\
\hline
\end{tabular}

Fonte: Elaborado a partir de Gutiérrez, 2003 citado por, Ramos 2012:85.

De acordo com Rubio, o financiamento público de partidos políticos e campanhas eleitorais produz os seguintes incentivos:

"Gera condições de competição eleitoral equitativa; promove a participação de partidos ou candidatos que carecem de recursos e não têm capacidade de arrecadação; evita a pressão direta ou indireta dos capitalistas e doadores sobre os atores políticos; diminui a necessidade de fundos dos partidos e candidatos; reduz o potencial de corrupção; contribui para a sustentação e o fortalecimento dos partidos como atores fundamentais para $\mathrm{o}$ funcionamento das democracias representativas". (RUBIO, 2005:8). 
De acordo com Rodrigues (2012) o financiamento partidário é um fator de relevância para a própria vitalidade da democracia. $\mathrm{O}$ financiamento público ${ }^{27}$ tem ganhado terreno em todos os países democráticos. Assim Rodrigues (2012), citando Van Biezen (2010: 79), realça que os partidos políticos em quase três quartos das democracias liberais modernas têm acesso ao financiamento público direto. Apesar da reconhecida importância do financiamento público na vida democrática, ela vem entrando num debate acadêmico e político, entre os defensores e opositores.

A Alemanha adotou um sistema público de financiamento partidário no qual, segundo Rodrigues (2012) os partidos são reconhecidos constitucionalmente como instituições fundamentais ao processo político não apenas por sua função de cunho eleitoral, mas, sobretudo, como instrumentos que viabilizam a participação popular. Seria, por exemplo, o caso da Alemanha que introduziu o financiamento público para os partidos desde 1959, tendo como objetivo garantir o trabalho partidário de educação política.

Num grupo de 10 países (Espanha, Portugal, Israel, EUA, Grã-Bretanha, México, Argentina, Itália, Alemanha e África do Sul) analisados por Rodrigues (2012) depara-se que apenas nos Estados Unidos e na Grã-Bretanha os partidos não têm direito a verba pública para o custeio de suas despesas correntes.

No entanto, é incontestável a tese da necessidade dos recursos por parte dos partidos políticos, dada a sua função de representação que os credores depositam neles. Assim, Speck (2002) salientou que o acesso da massa dos cidadãos à política encareceu o custo da competição política por dois motivos: a necessidade de comunicação com um eleitorado de massa e a transformação do engajamento político em profissão. Speck realça o seguinte:

"Em sistemas com eleições competitivas a propaganda eleitoral é um ingrediente necessário para a comunicação entre os cidadãos e os candidatos a cargos políticos. A competição por votos seria impossível sem os recursos necessários para convencer o eleitor. $\mathrm{O}$ dinheiro tem um papel positivo na competição política, mas também há riscos decorrentes do financiamento político". (Speck, 2006:154)

\footnotetext{
${ }^{27}$ Estamos a referir ao financiamento público, não exclusivamente público.
} 
Existem estudos que apresentam uma relação direta entre os gastos eleitorais e o sucesso eleitoral. Samuels (2001), ao estudar o impacto dos gastos de campanhas sobre o resultado eleitoral nas eleições de 1994 para a Câmara dos Deputados brasileira, concluiu que os gastos de campanhas influenciam os resultados eleitorais em igual maneira aos que estão no poder e aos desafiantes. De acordo com Krasnos (1988), os gastos eleitorais têm um impacto sobre os resultados eleitorais, independentemente de se tratar de o partido da posição ou da oposição. Levitt (1994) salienta que, mesmo nos casos em que existe apenas uma pequena probabilidade de os gastos afetarem os resultados das eleições, vale a pena fazer o gasto para conseguir votos. Os estudos dos autores mencionados nos permitem inferir que os gastos eleitorais têm um impacto direto sobre o sucesso/insucesso eleitoral.

Partindo dessa discussão teórica sobre o financiamento partidário, iremos analisar os sistemas de financiamentos nos cinco Países Africanos de Língua Oficial Português (PALOP). Esses cinco países foram ex-colônias portuguesas, tendo sido independentes entre 1973 a 1975. A Guiné-Bissau foi o primeiro país a tornar-se independente, em Setembro de 1973, realizando a sua primeira eleição multipartidária em 1994. Moçambique foi o segundo país a tornar-se independente em Junho de 1975, realizando a sua primeira eleição multipartidária em 1994. Já Cabo Verde e São Tomé e Príncipe se tornaram independentes em Julho de 1975, realizando as suas primeiras eleições multipartidárias em 1991. Angola foi o último país a tornar-se independente em Novembro de 1975, realizando a sua primeira eleição multipartidária em 1992.

As tabelas que se seguem, apresentam os dados sobre o financiamento partidário nos cinco países PALOP, comparativamente.

Tabela 4. Financiamento Público direto: Regras de acesso, distribuição e uso.

\begin{tabular}{|l|l|l|l|l|}
\hline PALOP & Financiamento Público & $\begin{array}{l}\text { Critérios de } \\
\text { elegibilidade }\end{array}$ & Formas de alocação & $\begin{array}{l}\text { Como deve ser usado o } \\
\text { Financiamento Publico }\end{array}$ \\
\hline Angola & Sim & Participação em eleição & $\begin{array}{l}\text { Igual a todos os } \\
\text { partidos. }\end{array}$ & Gastos de campanha \\
\hline Cabo Verde & Sim & Participação em eleição & Proporcional aos votos & Não existe uma \\
\hline
\end{tabular}




\begin{tabular}{|l|l|l|l|l|}
\hline & & & obtidos na eleição. & $\begin{array}{l}\text { legislação aplicável em } \\
\text { como o financiamento } \\
\text { deve ser usado. }\end{array}$ \\
\hline Guine Bissau & Não existe & Sem dados & Sem dados & Sem dados \\
\hline Moçambique & Sim & Participação na eleição. & $\begin{array}{l}\text { Proporcional aos } \\
\text { assentos recebidos; e } \\
\text { proporcional aos } \\
\text { candidatos em campo. }\end{array}$ & $\begin{array}{l}\text { Atividades do partido } \\
\text { em curso. }\end{array}$ \\
\hline São T. Príncipe & Sim & $\begin{array}{l}\text { Representação em } \\
\text { órgãos eleito; Ações de } \\
\text { votos na eleição } \\
\text { Anterior; Número de } \\
\text { candidatos. }\end{array}$ & $\begin{array}{l}\text { Proporcional aos votos } \\
\text { obtidos na eleição. }\end{array}$ & $\begin{array}{l}\text { Não existe uma } \\
\text { legislação aplicável em } \\
\text { como o financiamento } \\
\text { deve ser usado. }\end{array}$ \\
\hline & & & &
\end{tabular}

Fonte: Elaborado a partir da base de $\operatorname{dados}^{28}$, da Internacional IDEA ${ }^{29}$.

Entre os países da PALOP, apenas Guiné-Bissau não tem o financiamento público direto aos partidos políticos. Entretanto, para ter direito ao financiamento público nos demais países os partidos políticos têm de participar nas eleições. Curioso notar que em Angola todo o partido tem direito ao financiamento público, independentemente dos votos obtidos. Já em Cabo Verde e os demais países (exceto Guiné-Bissau) o critério de alocação do financiamento depende dos votos obtidos. Assim, o partido com maior sucesso eleitoral tem direito a uma maior fatia de financiamento público. Em Cabo Verde e São Tomé e Príncipe a lei não especifica como deve ser usado o financiamento público, porém em Angola deve ser usado nos gastos das campanhas. Em Moçambique o montante do financiamento deve ser usado nas atividades do partido.

A tabela a seguir apresenta os dados sobre o financiamento público indireto, as regras do acesso e a sua distribuição e uso.

\footnotetext{
${ }^{28}$ Os dados originais encontram-se em inglês. Responsabilizamos pelos eventuais erros da tradução.

${ }^{29}$ http://www.idea.int/political-finance/index.cfm, acessado em 18.11.2014.
} 
Tabela 5. Financiamento Público Indireto.

\begin{tabular}{|c|c|c|c|}
\hline PALOP & $\begin{array}{l}\text { Acesso gratuito } \quad \text { ou } \\
\text { subsidiado à mídia pelos } \\
\text { Partidos Políticos. }\end{array}$ & $\begin{array}{l}\text { Critérios alocação de } \\
\text { acesso à mídia }\end{array}$ & $\begin{array}{l}\text { Outra Forma } r \\
\text { Financiamento } \quad \text { Público } \\
\text { Indireto }\end{array}$ \\
\hline Angola & Acesso Gratuito & $\begin{array}{l}\text { Igual a todos os } \\
\text { partidos políticos }\end{array}$ & $\begin{array}{l}\text { Todas as partes têm o } \\
\text { direito de "instalações } \\
\text { públicas; e concessão de } \\
\text { apoio e subsídios". }\end{array}$ \\
\hline Cabo Verde & Acesso Gratuito & $\begin{array}{l}\text { Apresentação de } \\
\text { candidatos num } \\
\text { mínimo de cinco } \\
\text { circulo eleitoral }^{30} \text {. }\end{array}$ & $\begin{array}{l}\text { Espaço para materiais de } \\
\text { campanha; Instalação para } \\
\text { reuniões de campanha. }\end{array}$ \\
\hline Guiné- Bissau & Acesso Gratuito & $\begin{array}{l}\text { Igual a todos os } \\
\text { partidos políticos }\end{array}$ & $\begin{array}{l}\text { Espaço para materiais de } \\
\text { campanha; benefícios } \\
\text { fiscais. }\end{array}$ \\
\hline Moçambique & Acesso Gratuito & $\begin{array}{l}\text { Igual a todos os } \\
\text { partidos políticos. }\end{array}$ & Não existe \\
\hline São T. Príncipe & Não existem dados & Não existem dados & Benefícios fiscais \\
\hline
\end{tabular}

Fonte: Elaborado a partir da base de dados, da Internacional IDEA.

Em todos os países em análise, os partidos políticos têm acesso gratuito aos meios de comunicação social, com exceção de São Tomé e Príncipe, onde não encontramos os dados. Em Angola, os partidos têm ainda direito a instalações públicas e concessão de outros apoios. Curioso notar que, na Guiné-Bissau, os partidos não têm direito a financiamento público direto, mas têm direito ao financiamento público indireto atrás de concessão de espaços para materiais de campanhas e outros benefícios fiscais.

A tabela a seguir apresenta as proibições de doações privadas para os partidos políticos nos países em análise.

${ }^{30}$ De acordo com o art. 117ㅇ do Código eleitoral, 2010. 
Tabela 6.- proibições de doações aos partidos políticos nos PALOP.

\begin{tabular}{|l|l|l|c|l|}
\hline \multicolumn{1}{|c|}{ PALOP } & Estrangeiros & Empresas & Sindicatos & Anônimas \\
\hline Angola & Proibido & Permitido & Permitido & Permitido \\
\hline Cabo Verde & Proibido & Permitido & Permitido & Proibido $^{31}$ \\
\hline Guiné-Bissau & Proibido & Permitido & Permitido & Permitido \\
\hline Moçambique & Proibido & Proibido & Permitido & Não têm dados \\
\hline São T. Príncipe & Proibido & Proibido & Não têm dados & Proibido \\
\hline
\end{tabular}

Fonte: Elaborado a partir da base de dados, da Internacional IDEA.

Analisando a tabela acima podemos ver que o financiamento privado por parte dos estrangeiros é proibido nos cinco países. Porém, as empresas podem financiar os partidos em Angola, Cabo Verde e Guiné-Bissau, tendo Moçambique e São Tomé Príncipe proibido essa prática. Os sindicatos podem financiar quaisquer partidos políticos nos países em análise. Entretanto, em Cabo Verde e Moçambique as pessoas ou entidades anônimas podem financiar os partidos políticos. Por fim, as pessoas anônimas não podem financiar os partidos em Angola e São Tomé e Príncipe.

\footnotetext{
${ }^{31}$ Não existe uma proibição direta, mas sim a exigência de identificar e registar o doador.
} 
A tabela seguinte é uma continuidade da tabela anterior, apresenta as proibições, tanto de compra de votos, recursos do estado e limites dos gastos.

\section{Tabela 7. Proibições de Doações.}

\begin{tabular}{|l|l|l|l|}
\hline \multicolumn{1}{|c|}{ PALOP } & Compra de votos & Recursos do Estado & Limites dos gastos \\
\hline Angola & Proibido & Proibido & Não \\
\hline Cabo Verde & Proibido & Proibido & Sim \\
\hline Guiné-Bissau & Proibido & Proibido & Não \\
\hline Moçambique & Proibido & Proibido & Não \\
\hline São Tomé e Príncipe & Não têm dados & Não têm dados & Sim \\
\hline
\end{tabular}

Fonte: Elaborado a partir da base de dados, da Internacional IDEA.

A pratica da compra de votos é proibido em todos os países da PALOP com exceção de São Tomé e Príncipe nas quais não encontramos os dados disponíveis. Também é proibido o uso indevido dos recursos do estado para favorecer qualquer partido político em todos os países da PALOP, com exceção de São Tomé e Príncipe. Os partidos políticos não tem um limite de gastos em Angola, Guiné-Bissau e Moçambique. Apenas em Cabo verde e São Tomé e príncipe existe uma barreira imposta aos partidos políticos no que se refere aos gastos.

De acordo com art. $128^{\circ}$ do código eleitoral cabo-verdiano, os partidos políticos não podem gastar mais dos $80 \%$ do montante global da subvenção estatal na eleição em causa.

De uma maneira geral, nota-se que Cabo Verde e São Tomé e Príncipe são mais liberais, em termos de financiamento do que os demais PALOPs. Esses dois países não estabeleceram a maneira como o dinheiro deve ser utilizado e permitem doações de pessoas anônimas. 


\section{2 - Financiamento Partidário em Cabo Verde}

Assim como em vários países recém-democráticos, logo na abertura política os atores políticos reconheceram a importancia dos partidos políticos, aprovando assim os modelos do seu financiamento.

"Cabo Verde adoptou, desde o início do processo de democratização, o modelo misto de financiamento partidário. Este financiamento engloba quotas dos militantes, donativos de pessoas singulares e coletivas, rendimentos de bens e valores, direitos, participações e serviços próprios, empréstimos bancários e das instituições e as subvenções estatais". (Ramos, 2012:86).

Porém, vale ressaltar que em Cabo Verde são os resultados eleitorais que ditam o modo como o partido é financiado ao longo do tempo. Um tipo de recurso específico é garantido somente aos partidos que obtêm cadeiras no parlamento para o seu funcionamento, porém a lei não especifica como deve ser usado o dinheiro das subvenções.

Entretanto, existe uma subvenção pós-eleitoral que se destina a todos os partidos que concorrem às eleições, de acordo com o número dos votos obtidos na eleição. As subvenções estatais incluem recursos para o funcionamento dos partidos inscritos anualmente no orçamento do estado e para o financiamento das campanhas eleitorais nos anos eleitorais (Ramos, 2012).

O financiamento público das campanhas eleitorais é estabelecido no OGE (Orçamento Geral do Estado) no ano em que deva haver eleições e consiste na atribuição de setecentos e cinquentas escudos cabo-verdianos $(\mathrm{R} \$ 21,62){ }^{32}$ por cada voto válido para as eleições legislativas e presidenciais e quinhentos escudos caboverdianos $(\mathrm{R} \$ 15,86)^{33}$ nas eleições autárquicas ${ }^{34}$. (Código eleitoral, 2010)

A tabela a seguir apresenta sucintamente os fatores que fazem parte do financiamento partidário em Cabo Verde.

\footnotetext{
${ }^{32}$ http://www4.bcb.gov.br/pec/conversao/conversao.asp Convertido em 11.11.2014..

33 Idem.

${ }^{34}$ O financiamento das campanhas eleitorais é feita pós-eleições, os partidos recebem o dinheiro público dependendo do seu sucesso eleitoral.
} 
Tabela 8. Tipos de financiamentos dos partidos em Cabo Verde, por fonte de recursos.

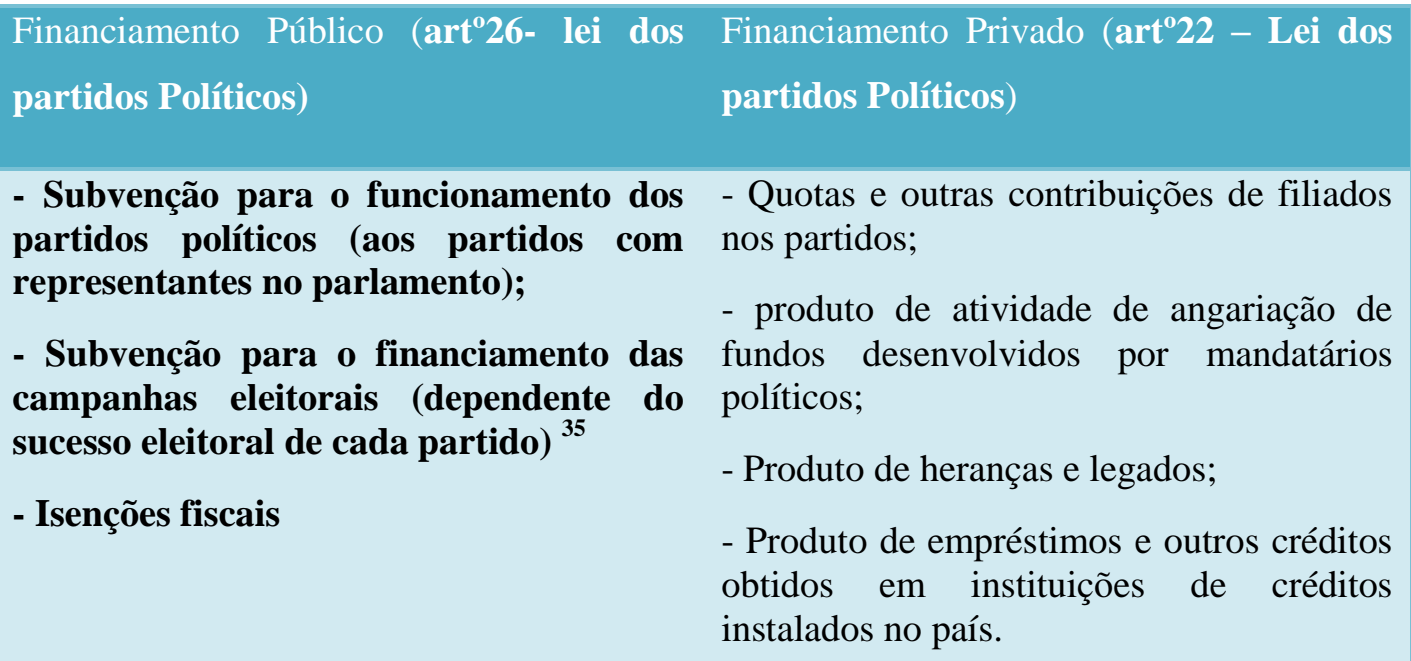

Fonte: elaboração própria, a partir da lei dos partidos políticos (1999).

Vale lembrar que são o Regime Jurídico dos Partidos Políticos e o Código Eleitoral que estabelecem os mecanismos de financiamento partidário, os limites para os gastos e contribuições nas campanhas eleitorais para os partidos e os candidatos, os mecanismos de prestação de contas e as formas de sua publicidade. O país adotou a exigência legal da prestação de contas, seja para o funcionamento dos partidos políticos seja para o financiamento das campanhas eleitorais.

De acordo com Ramos (2012) o sistema de financiamento partidário em Cabo Verde tem encorajado os partidos a optarem por uma estratégia de cartelização em nível de financiamento. Isso tendo em conta que o partido político para receber a subvenção estatal de funcionamento terá de ter representantes no parlamento nacional. Estes recursos são distribuídos de forma proporcional ao número de votos obtidos nas últimas eleições legislativas. Isso significa que os partidos pequenos se encontram em situação de desvantagem, ameaçando a sua sobrevivência uma vez que o partido é excluído do governo e do parlamento. A maioria dos pequenos partidos, como PSD e PRD, tem tido dificuldades em obter um score eleitoral que lhe permite representação parlamentar e, consequentemente, acesso às subvenções estatais anuais.

\footnotetext{
${ }^{35}$ Art $^{\circ} 190$ - código eleitoral, 2010.
} 
O modelo de financiamento adotado em Cabo Verde tem recebido críticas de vários analistas políticos como de líderes dos pequenos partidos que se sentem prejudicados e sem meios para se fortalecer através dos recursos estatais.

O líder da UCID $^{36}$ António Monteiro, em entrevista que me foi concedida recentemente ${ }^{37}$, entende que o atual modelo de financiamento partidário cabo-verdiano é injusto. De acordo com ele para o partido penetrar nos diversos setores da vida da nação e em todos os círculos eleitorais, são necessários muitos recursos financeiros e humanos. Entretanto, por falta de recursos, o partido não consegue realizar o trabalho necessário em todo o território cabo-verdiano. O líder da UCID defendeu na entrevista que o financiamento deveria conter duas parcelas, uma em que todos os partidos com assento parlamentar teriam o mesmo valor, mais outra adicional que seria em função do número dos deputados de cada um dos partidos, realçando ainda que deveria ter algum mecanismo de apoio aos partidos sem assento parlamentar.

Tendo em conta que nas eleições passadas a UCID concentrou a sua base eleitoral no círculo eleitoral de São Vicente, fez com que muitos o viam como sendo um partido regionalista. Porém, o líder da UCID afirmou na entrevista ${ }^{38}$ que a razão para não apresentar candidatos em todos os círculos é estritamente financeira, defendendo que normalmente as candidaturas são feitas aonde existe a possibilidade de ter um bom score eleitoral. Nesse sentido a UCID age estrategicamente nas eleições, posicionandose nos círculos que tem maior aceitação do eleitorado. De fato até a última eleição legislativa, a UCID não tinha diretórios políticos em todas as ilhas ${ }^{39}$, mais uma vez apresentando a questão financeira e humana como sendo a principal causa.

Entendemos que as estratégias e a forma como se fazem as campanhas eleitorais em Cabo Verde, onde os partidos gastam muito dinheiro para poder realizar os seus objetivos, condiciona muitas vezes as atividades dos pequenos partidos que queixam de falta de recursos.

\footnotetext{
${ }^{36}$ Ao longo da dissertação, iremos dar relevância a UCID, tendo em conta o seu papel no Parlamento cabo-verdiano como sendo único partido pequeno a eleger deputados nas duas ultimas eleições legislativas.

${ }^{37}$ Entrevista realizada por mim ao presidente da UCID via email em Julho de 2014.

${ }^{38}$ Idem
} 
Sabendo que para ganhar eleições o partido político tem de fazer chegar ao eleitorado as suas propostas e programas políticos, o partido tem de estar enraizado e ter diretórios políticos em todos os círculos eleitorais.

A UCID tem direito a uma subvenção do estado bem menor do que os demais partidos. Por isso, só lhe resta recorrer a outras formas de financiamento tais como as anuidades dos militantes. Curioso esse aspecto, pois o líder da UCID afirma que muitas das vezes sente receio em cobrar as anuidades com medo de que os militantes desistam da filiação, prejudicando mais o desenvolvimento das atividades da UCID. (Ramos, 2012).

Este sistema de financiamento dos partidos em Cabo Verde é visto por alguns autores políticos dentro da perspectiva da cartelização. Livramento (2005), um dos exdirigentes do PRD, defendeu que "longe vão os tempos em que os partidos representavam a sociedade civil ou em que serviam de intermediação entre o Estado e os cidadãos"; hoje, é o Estado o intermediário entre os partidos e os cidadãos. Os partidos políticos aproximaram-se tanto do Estado e tornaram-se tão dependentes do mesmo que passaram a fazer parte dele. Essa inferência vai à mesma linha do que Ramos (2012:89) defendeu:

Em Cabo Verde o financiamento público tem encorajado os partidos a adoptarem uma estratégia de cartelização ao nível do financiamento partidário. Os partidos com representação parlamentar têm uma aproximação privilegiada aos recursos estatais e aos meios de comunicação social. O Staff dos grupos parlamentares na Assembleia Nacional é pago, na totalidade, por fundos estatais.

Reis (2005), outro ex-dirigente de PRD acabava mesmo por defender que o Estado devia assumir o papel mais preponderante na questão do financiamento, que facilitasse tanto aos pequenos partidos como os grandes partidos. Defendeu que " $A$ dignidade conferida pela constituição aos partidos, deveria colocá-los numa posição liberta dos constrangimentos das dívidas, e o Estado deveria assumir o papel mais preponderante nessa problemática". (In jornal Horizonte, 17.03.95). Assim, o mecanismo de financiamento através da subvenção estatal tem sido contestado pelos partidos que têm pouca ou nenhuma representação parlamentar e fragilizado o reconhecimento da função pública dos pequenos partidos no sistema democrático. $\mathrm{O}$ fato da entrega dos subsídios ser depois das eleições prejudica os pequenos partidos, 
visto que não conseguem arrecadar grandes montantes provenientes do financiamento privado. Zovato (2005) defende essa tese explicando que a entrega do subsidio após as eleições desfavorece aqueles partidos de criação recente, com menores recursos financeiros ou com menor capacidade creditícia.

Acreditamos que alguns dados são esclarecedores. Podemos notar, ao analisar os gráficos abaixo, onde se mostra o número dos votos e as respectivas subvenções estatais recebidas nas últimas três eleições legislativas. Entretanto, o MPD e o PAICV receberam as maiores parcelas da subvenção estatal, isto porque tiveram melhores desempenhos eleitorais. Em Cabo Verde quanto mais votos o partido obtiver maior será a parcela da sua subvenção.

Gráfico 2. Número de votos de 2001

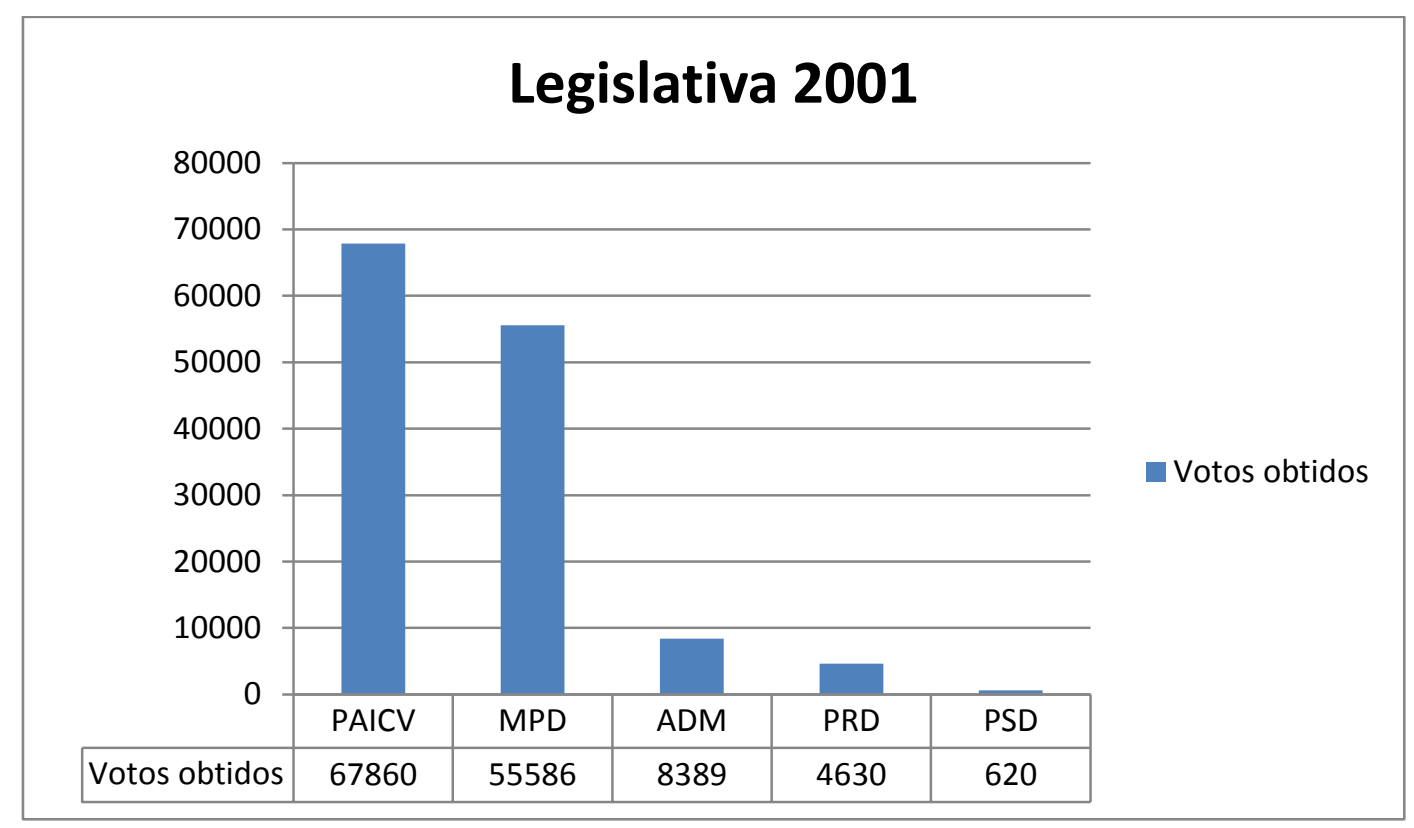

Fonte: Elaboração própria baseado nas contas eleitorais da $\mathrm{CNE}^{40}$ de 2001.

\footnotetext{
${ }^{40}$ Comissão Nacional de Eleições
} 
Gráfico 3. Percentagens da subvenção estatal recebida.

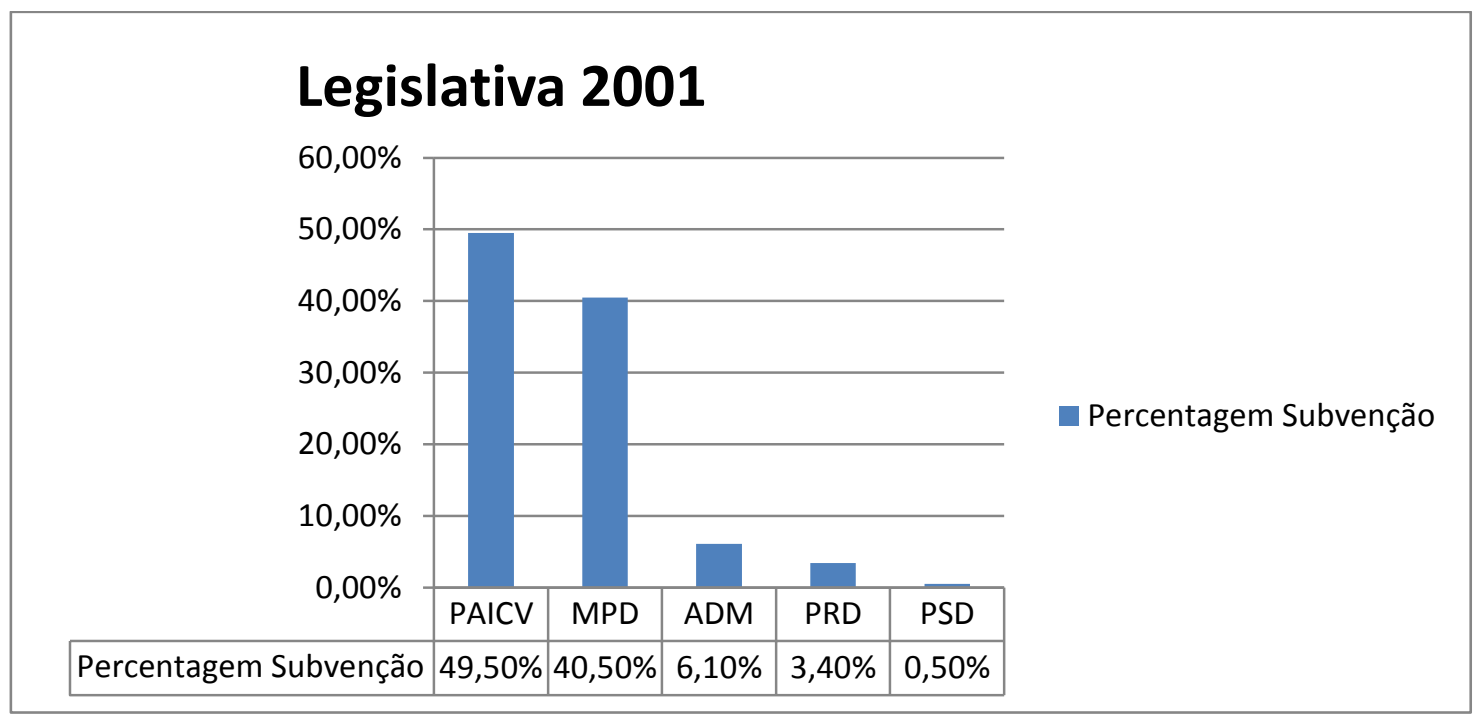

Fonte: Elaboração própria baseado nas contas eleitorais da $\mathrm{CNE}^{41}$ de 2001.

Como podemos observar, a terceira força política nas eleições legislativas de 2001 foi a $\mathrm{ADM}^{42}$, composta por uma coligação entre $\mathrm{UCID}^{43}, \mathrm{PCD}^{44}$ e $\mathrm{PTS}^{45}$. A ADM conseguiu 8389 votos válidos, obtendo uma pequena porção de subvenção, $(6,10 \%)$ tendo em conta que elegeu dois deputados à Assembleia Nacional.

O quarto partido concorrente foi o $\mathrm{PRD}^{46}$, que conseguiu 4630 votos válidos tendo direito a uma porção de subvenção estatal $(3,40 \%)$. Tendo em conta o número de votos, não conseguiu eleger nenhum deputado para Assembleia Nacional. Já o partido menos votado foi o $\mathrm{PSD}^{47}$, que conseguiu o menor número de votos e uma pequena porção de subvenção $(0,50 \%)$. Consequentemente, não conseguiu eleger nenhum deputado.

\footnotetext{
${ }^{41}$ Comissão Nacional de Eleições

${ }^{42}$ Aliança Democrática para a Mudança

${ }^{43}$ União Cabo-verdiana Independente Democrática

${ }^{44}$ Partido de Convergência Democrática

${ }^{45}$ Partido de trabalho social

${ }^{46}$ Partido de Renovação Democrática

${ }^{47}$ Partido Social Democrática
} 
Gráfico 4. Número de votos de 2006.

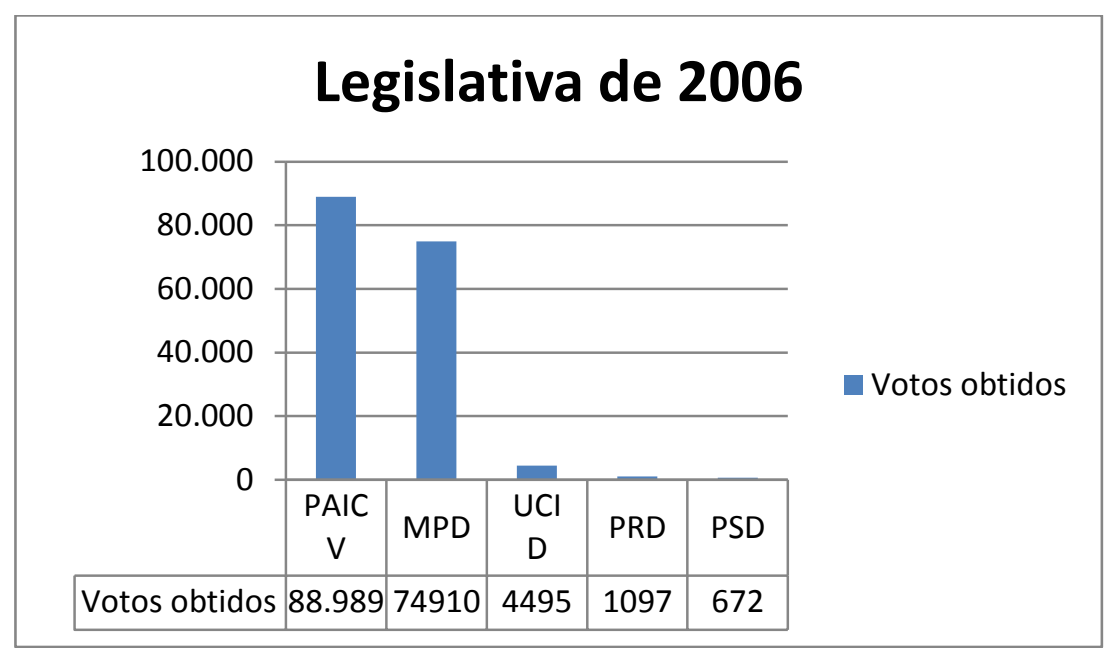

Fonte: Elaboração própria baseado nas contas eleitorais da CNE de 2006.

Gráfico 5. Percentagens da subvenção estatal recebida.

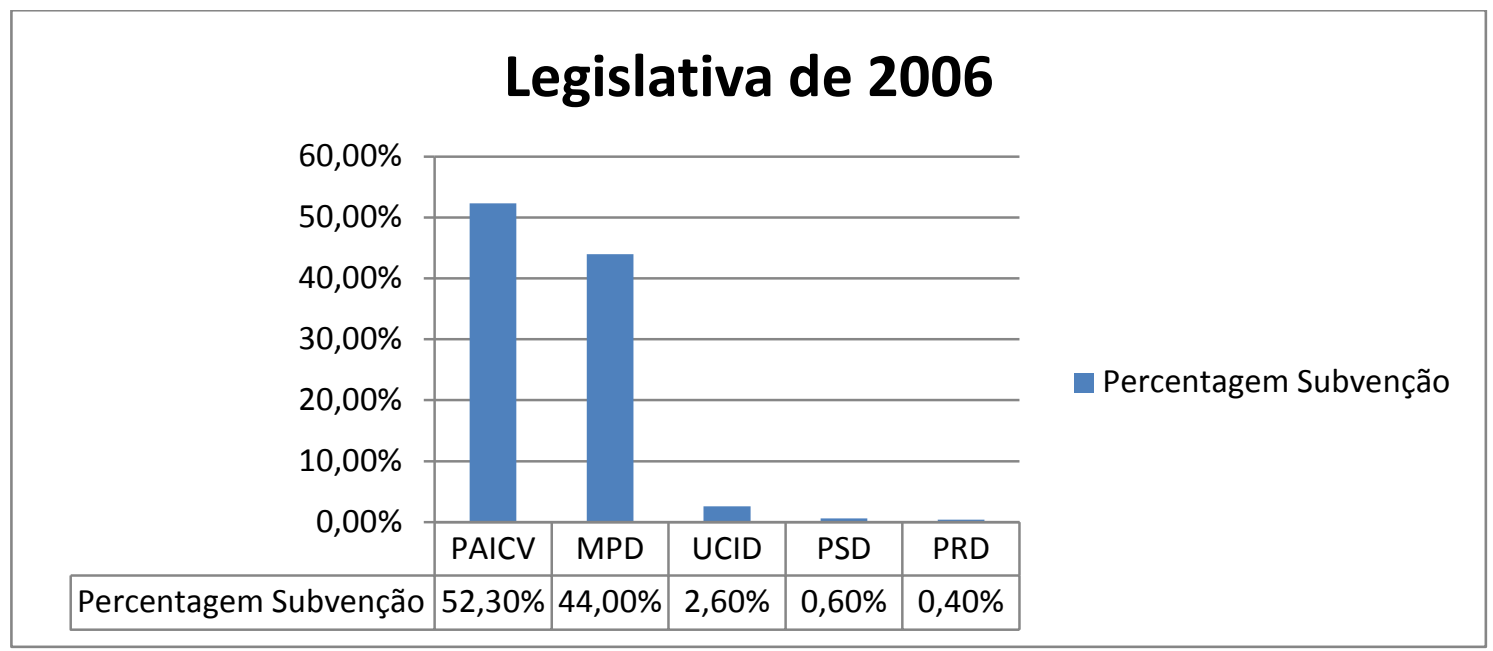

Fonte: Elaboração própria baseado nas contas eleitorais da CNE de 2006.

Nas eleições legislativas de 2006 se, repetiu o mesmo cenário em relação ao terceiro partido, só que dessa vez foi a UCID que conseguiu eleger os seus dois deputados. Nota-se que a coligação formada na eleição legislativa de 2001 não participou das eleições por razões desconhecidas. O PAICV ganhou as eleições conseguindo maior número de votos e, portanto, com direito a uma percentagem maior da subvenção estatal $(52,30 \%)$, tendo direito a mais de metade do total das subvenções. 
O MPD continuou sendo o maior partido da oposição conseguindo um total de 44, \% das subvenções. Essa quantia foi menor do que a obtida pelo PAICV, porém maior que o total dos outros três partidos concorrentes nas eleições legislativas de 2006. A UCID, por sua vez, conseguiu um número expressivo de votos, elegendo dois deputados num único círculo eleitoral (São Vicente) e tendo direito a 2,6\% das subvenções. O PSD foi o quarto partido mais votado com direito a $0,4 \%$ do total das subvenções estatais destinado na eleição em causa. Por fim, o PTS manteve o score eleitoral conseguido por PSD nas eleições legislativas de 2001, visto que conseguiu arrecadar 0,6\% do total do orçamento que o estado tinha previsto para eleição em causa.

Gráfico 6. Número de votos de 2011.

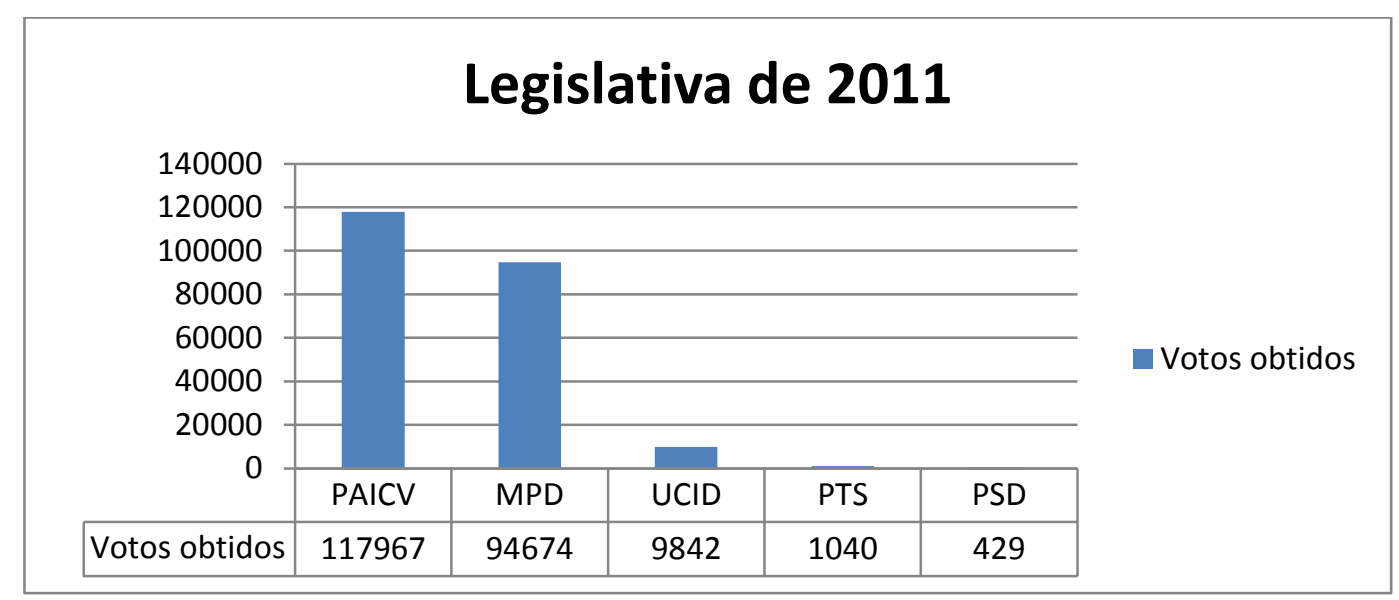

Fonte: Elaboração própria baseado nas contas eleitorais da CNE de 2011. 
Gráfico 7. Percentagens da subvenção estatal recebida, legislativa de 2011.

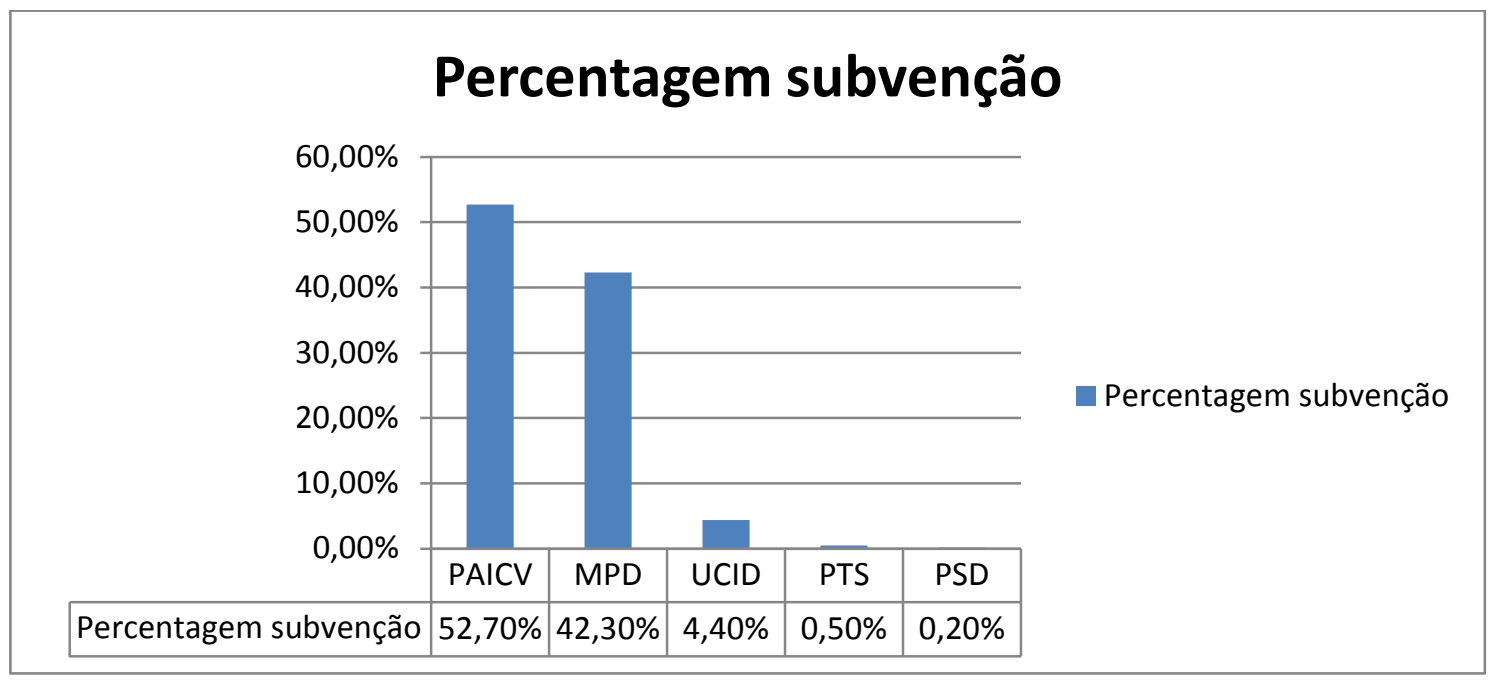

Fonte: Elaboração própria baseado nas contas eleitorais da CNE de 2011.

As últimas eleições legislativas realizada em Cabo Verde (2011) repetiram quase os mesmos resultados dos pleitos anteriores, tendo direito o PAICV à maior fatia do bolo orçamental $(52,7 \%)$. O MPD conseguiu aumentar o número de votos em relação à eleição de 2006, mas diminuiu o percentual da subvenção $(42,3 \%)$ tendo em conta que os outros partidos aumentaram significativamente o score eleitoral. A UCID manteve seus dois deputados, aumentando o seu número de votos e percentual da subvenção $(0,2 \%)$. O PSD conseguiu $0,2 \%$ da subvenção diminuindo o percentual da subvenção em relação à eleição de 2006. O PTS que não apresentou candidato às eleições de 2006 conseguiu um número considerável de votos, tendo direito a $0,5 \%$ do total da subvenção.

De imediato, parece lógico afirmar que existe uma tendência bem grande para a concentração dos votos nos maiores partidos, tendo em conta os mecanismos de financiamento dos partidos políticos em Cabo Verde. Quanto maior for o partido, maior será o acesso aos recursos públicos. Essa, aliás, é uma das conclusões a que chega a Ramos (2012:91) quando compara as eleições de 2001 e 2006. 
Como foi dito anteriormente Cabo Verde adota um sistema misto de financiamento, permitindo aos privados intervir no apoio aos partidos. Isso significa que, em tese, existem outras formas de angariar recursos para os pequenos partidos.

No financiamento privado, os partidos podem recorrer aos empréstimos bancários, ou receber doações das pessoas singulares e coletivas. Porém, a lei ${ }^{48}$ põe um limite onde os empréstimos não podem exceder 50\% do montante global da subvenção estatal prevista para as eleições em causa. Trata-se, porém, de uma estratégia altamente arriscada, sobretudo porque, na maioria das vezes os pequenos partidos não conseguem o número de votos suficiente e acabam por se endividar junto aos bancos.

A tabela abaixo apresenta os dados dos empréstimos bancários (convertidos em $\mathrm{R} \$$ na data 05.11.2014) ${ }^{49}$ feitos pelos partidos nas eleições legislativas de 2001-2011.

Tabela 9: Empréstimos bancários ${ }^{50}$ nas eleições de 2001, 2006 e 2011.

\begin{tabular}{|c|c|c|c|}
\hline & 2001 & 2006 & 2011 \\
\hline Partidos & Valor absoluto & Valor absoluto & Valor absoluto \\
\hline PAICV & $\mathrm{R} \$ 526.656,00$ & $\mathrm{R} \$ 903.245,00$ & $\mathrm{R} \$ 2.938 .530,00$ \\
\hline MPD & $\mathrm{R} \$ 576.030,00$ & $\mathrm{R} \$ 423.886,32$ & $\mathrm{R} \$ 1.777 .510,80$ \\
\hline $\mathrm{ADM}^{51}$ & $\mathrm{R} \$ 246.870,00$ & ------------- & ------- \\
\hline PRD & $\mathrm{R} \$ 329.160,00$ & 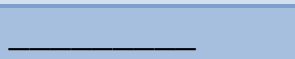 & ------- \\
\hline PSD & ----------------- & $\mathrm{R} \$ 19.355,25$ & ------------- \\
\hline UCID & --------- & $\mathrm{R} \$ 30.968,40$ & $\mathrm{R} \$ 189.905,00$ \\
\hline PTS & ----------- & -------------- & $\mathrm{R} \$ 39.980,00$ \\
\hline Total & $\mathrm{R} \$ 1.678 .716,00$ & $\mathrm{R} \$ 1.377 .454,97$ & $\mathrm{R} \$ 4.945 .925,8$ \\
\hline
\end{tabular}

Fonte: Elaboração própria baseado nas contas eleitorais da CNE.

\footnotetext{
${ }^{48}$ Art.128ㅇ Código eleitoral, 2010.

${ }^{49}$ Os valores monetários que estão sendo apresentados ao longo da dissertação, foram convertidos em reais. A conversão foi realizada em 04.11.2014 pelo site

http://www4.bcb.gov.br/pec/conversao/conversao.asp; Com a data da cotação de acordo com o período eleitoral em que houve eleição.

${ }^{50}$ De acordo com o art. 128 do código eleitoral (2010) os partidos políticos não podem contrair empréstimos mais do que $50 \%$ do montante global da subvenção.

${ }^{51}$ Aliança Democrática para Mudança (coligação UCID+PCD+PTS)
} 
Na primeira observação da tabela acima, nota-se uma diferença nas três eleições, sendo a de 2011 como a eleição mais cara desde a transição política, a julgar pelos dados disponíveis. O PAICV triplicou o valor emprestado na referida eleição comparativamente às demais eleições passadas. Já o MPD duplicou o valor do empréstimo junto das bancas, e a UCID por sua vez obteve uma quantia muito superior em relação à eleição de 2006. O MPD que obteve um percentual de votos menor em relação ao PAICV emprestou maior quantia de dinheiro em relação aos demais partidos. Na eleição de 2006, emprestou aproximadamente a metade do que tinha emprestado em 2001. Já o PAICV manteve os valores altos, tendo aumentado o valor de empréstimos.

Os valores dos empréstimos não deixam de ser interessantes, pois nos mostram que as eleições estão ficando mais caras. Entretanto, o dado mais interessante se refere ao valor percentual dos empréstimos quando comparados entre partidos grandes e pequenos. Assim, nota-se que os grandes partidos tendem a realizar maiores empréstimos privados enquanto os pequenos partidos deixaram de obtê-los. O PAICV e o MPD foram responsáveis em 2001 e 2011 por, respectivamente, 65,5\% e 92,3\% dos empréstimos. De certa forma isso é facilmente explicável. O fato é que os bancos tendem a emprestar maior quantidade de dinheiro aos partidos com maiores chances de vencer as eleições e que tem como restituir o dinheiro emprestado, conclusão a que chega Ramos (2012) em relação às eleições de 2001 e 2006. Acreditamos também que os pequenos partidos agem estrategicamente pedindo menos dinheiro tendo em conta a sua dificuldade em penetrar e conseguir mais votos.

Em relação ao conjunto de receitas totais que os partidos conseguem, a tabela abaixo apresenta a subvenção estatal recebida e o total das receitas das campanhas feitas pelos partidos políticos para as últimas três eleições. A categoria das receitas inclui os empréstimos bancários, mais os donativos de instituições particulares e as quotas dos militantes $^{52}$. Nota-se a desproporção enorme entre pequenos e grandes partidos. Existe também um aumento considerável das receitas dos partidos em geral, tendo em contas essas três eleições analisadas. 
A tabela 10. Quadro das subvenções e receitas durante as três ultima legislativas.

\begin{tabular}{|c|c|c|c|c|c|c|}
\hline & 2001 & & 2006 & & 2011 & \\
\hline Partido & $\begin{array}{l}\text { Subvenção } \\
\text { estatal }\end{array}$ & $\begin{array}{l}\text { Receitas } \\
\text { campanhas }^{53}\end{array}$ & $\begin{array}{l}\text { Subvenção } \\
\text { estatal }\end{array}$ & $\begin{array}{l}\text { Receitas } \\
\text { campanhas }\end{array}$ & $\begin{array}{l}\text { Subvenção } \\
\text { estatal }\end{array}$ & $\begin{array}{l}\text { Receitas } \\
\text { campanhas }\end{array}$ \\
\hline PAICV & $\begin{array}{l}\mathrm{R} \$ 444.917,30 \\
(\mathbf{4 9 , 5 \% )}\end{array}$ & $\begin{array}{l}\mathrm{R} \$ 678.095,67 \\
(\mathbf{3 1 , 4 \% )}\end{array}$ & $\begin{array}{l}\mathrm{R} \$ 918.615,6 \\
5(\mathbf{5 2 , 3 \% )}\end{array}$ & $\begin{array}{l}\mathrm{R} \$ 1.384 .075, \\
27(\mathbf{4 8 , 9 \% )}\end{array}$ & $\begin{array}{l}\mathrm{R} \$ 1.770 .389,7 \\
5(\mathbf{5 2 , 7 \% )}\end{array}$ & $\begin{array}{l}\mathrm{R} \$ 2.955 .765, \\
10(\mathbf{5 5 , 0 \%})\end{array}$ \\
\hline MPD & $\begin{array}{l}\mathrm{R} \$ 364.444,05 \\
(\mathbf{4 0 , 5 \% )}\end{array}$ & $\begin{array}{l}\mathrm{R} \$ 770.631,06 \\
(\mathbf{3 5 , 7 \% )}\end{array}$ & $\begin{array}{l}\mathrm{R} \$ 773.280,9 \\
5(\mathbf{4 4 , 0 \% )}\end{array}$ & $\begin{array}{l}\mathrm{R} \$ 1.344 .708 \\
73(\mathbf{4 7 , 5 \% )}\end{array}$ & $\begin{array}{l}\mathrm{R} \$ 1.420 .820,0 \\
6(\mathbf{4 2 , 3 \% )}\end{array}$ & $\begin{array}{l}\mathrm{R} \$ 2.089 .213, \\
10(\mathbf{3 8 , 9 \% )}\end{array}$ \\
\hline $\mathrm{ADM}^{54}$ & $\begin{array}{l}\mathrm{R} \$ 55.001,64 \\
(\mathbf{6 , 1 \%})\end{array}$ & $\begin{array}{l}\mathrm{R} \$ 307.065,60 \\
(\mathbf{1 4 , 2 \% )}\end{array}$ & & & 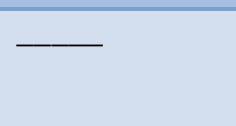 & \\
\hline PRD & $\begin{array}{l}\mathrm{R} \$ 30.356,13 \\
(\mathbf{3}, \mathbf{4 \%})\end{array}$ & $\begin{array}{l}\mathrm{R} \$ 393.631,73 \\
(\mathbf{1 8 , 2 \% )}\end{array}$ & $\begin{array}{l}\mathrm{R} \$ 11.324,11 \\
(\mathbf{0 , 6 \% )}\end{array}$ & ------------- & & \\
\hline PSD & $\begin{array}{l}\mathrm{R} \$ 4.064,97 \\
(\mathbf{0 , 5 \% )}\end{array}$ & $\begin{array}{l}\mathrm{R} \$ 9.285,50 \\
(\mathbf{0 , 4 \% )}\end{array}$ & $\begin{array}{l}\mathrm{R} \$ 6.936,92 \\
(\mathbf{0 , 4 \% )}\end{array}$ & $\begin{array}{l}\mathrm{R} \$ 21.545,36 \\
(\mathbf{0 , 8 \% )}\end{array}$ & $\begin{array}{l}\mathrm{R} \$ 6.438,22 \\
(\mathbf{0 , 2 \% )}\end{array}$ & $\begin{array}{l}\mathrm{R} \$ 3.102,67 \\
(\mathbf{0 , 1 \% )}\end{array}$ \\
\hline UCID & & & $\begin{array}{l}\mathrm{R} \$ 46.400,99 \\
(\mathbf{2 , 6 \% )}\end{array}$ & $\begin{array}{l}\mathrm{R} \$ 46.400,99 \\
(\mathbf{2 , 8 \% )}\end{array}$ & $\begin{array}{l}\mathrm{R} \$ 147.703,82 \\
(\mathbf{4 , 4 \% )}\end{array}$ & $\begin{array}{l}\mathrm{R} \$ 284.886,1 \\
5(\mathbf{5 , 3 \% )}\end{array}$ \\
\hline PTS & & & & & $\begin{array}{l}\mathrm{R} \$ 15.607,80 \\
(\mathbf{0 , 5 \% )}\end{array}$ & $\begin{array}{l}\mathrm{R} \$ 40.020,00 \\
(\mathbf{0 , 7 \% )}\end{array}$ \\
\hline Total & $\begin{array}{l}\mathrm{R} \$ 898.784,09 \\
(\mathbf{1 0 0 \%})\end{array}$ & $\begin{array}{l}\mathrm{R} \$ 2.158 .791,52 \\
(\mathbf{1 0 0 \% )}\end{array}$ & $\begin{array}{l}\mathrm{R} \$ 1.756 .558, \\
56(\mathbf{1 0 0 \% )}\end{array}$ & $\begin{array}{l}\mathrm{R} \$ 2.796 .730 \\
35(\mathbf{1 0 0 \% )}\end{array}$ & $\begin{array}{l}\mathrm{R} \$ 3.360 .959, \\
64(\mathbf{1 0 0 \% )}\end{array}$ & $\begin{array}{l}\mathrm{R} \$ 5.374 .705, \\
61(\mathbf{1 0 0 \% )}\end{array}$ \\
\hline
\end{tabular}

Fonte: Elaboração própria, baseado nas contas eleitorais da CNE.

Os grandes partidos conseguem maiores subvenções estatais, lembrando que quanto mais votos conseguir obter maior será o volume de subvenções estatais. Durante as três eleições, o PAICV foi o que conseguiu a maior fatia das subvenções. Nas eleições de 2006 e 2011, o PAICV conseguiu ter acesso a mais de metade do total das subvenções estatais.

Analisando as duas tabelas anteriores verifica-se que o empréstimo bancário tem um maior peso de entre as receitas das campanhas. $78 \%$ das receitas das campanhas na eleição legislativa de 2001 provinham dos empréstimos bancários, enquanto que na eleição legislativa de 2006 o percentual é menos, sendo que apenas 49\% das receitas das campanhas provinham de empréstimos bancários. Já na ultima eleição legislativa (2011)

\footnotetext{
${ }^{53}$ Os valores das receitas de campanhas incluem contribuições de candidatos, donativos de instituições e particulares, empréstimos bancários e alienações de bens.
} 
depara-se com um percentual bem alto, onde $92 \%$ das receitas das campanhas provinham dos empréstimos bancários.

Apresentando o valor total das subvenções e das receitas arrecadas durante as três eleições legislativas (2001, 2006 e 2011), iremos analisar na tabela a seguir os gastos totais dos partidos durantes as três eleições legislativas em análise.

\section{Tabela 11: Gastos totais dos partidos durantes as três últimas eleicões legislativas}

\begin{tabular}{|l|l|l|l|}
\hline Partido & $\mathbf{2 0 0 1}$ & $\mathbf{2 0 0 6}$ & $\mathbf{2 0 1 1}$ \\
\hline PAICV & $\mathrm{R} \$ 1.103 .349,01$ & $\mathrm{R} \$ 1.389 .384,81$ & $\mathrm{R} \$ 2.955 .746,59$ \\
\hline MPD & $\mathrm{R} \$ 1.492 .019,74$ & $\mathrm{R} \$ 1.298 .526,26$ & $\mathrm{R} \$ 2.052 .071,10$ \\
\hline ADM $^{\mathbf{5}}$ & $\mathrm{R} \$ 307.436,22$ & & \\
\hline PRD & $\mathrm{R} \$ 423.146,30$ & & \\
\hline PSD & $\mathrm{R} \$ 8.046,35$ & $\mathrm{R} \$ 21.628,01$ & $\mathrm{R} \$ 6.694,47$ \\
\hline UCID & & $\mathrm{R} \$ 78.492,63$ & $\mathrm{R} \$ 284.886,15$ \\
\hline PTS & & & $\mathrm{R} \$ 38.551,57$ \\
\hline Total & $\mathrm{R} \$ 3.333 .997,64$ & $\mathrm{R} \$ 2.788 .031,71$ & $\mathrm{R} \$ 5.337 .949,88$ \\
\hline
\end{tabular}

Fonte: Elaboração baseada nas contas eleitorais da CNE.

A tabela acima mostra que existe uma tendência das campanhas eleitorais se tornarem cada vez mais caras. Entretanto, nota-se uma diminuição nos gastos entre a eleição legislativa de 2001 e legislativa de 2006. Em 2011, porém, duplicou-se o gasto total das despesas dos partidos políticos. Curioso notar que em 2011 o PAICV gastou muito mais do que o total dos gastos totais da eleição de 2006.

Apresentando os gastos gerais das três ultimas eleições, iremos analisar em quê os partidos gastam tanto dinheiro. Para analisar este aspecto filtramos os itens que consideramos ser importantes e que apresentam maiores somas de dinheiro. As duas tabelas abaixo sintetizam os itens em que os partidos gastam mais dinheiro nas duas últimas eleições legislativas (2006 e 2011).

Tabela 12: Gastos por itens na Legislativa de 2006.

\begin{tabular}{|c|c|c|c|c|c|}
\hline Tipos de & Partido & & & & \\
\hline Gastos & PAICV & MPD & UCID & PSD & PRD \\
\hline
\end{tabular}




\begin{tabular}{|l|l|l|l|l|l|}
\hline Propaganda/Publicidade/animação & $\mathrm{R} \$ 147.525,83^{56}$ & $\mathrm{R} \$ 719.935,59$ & $\mathrm{R} \$ 46.429,93$ & $\mathrm{R} \$ 12.096,09$ & sem dados \\
\hline $\begin{array}{l}\text { Aluguel de viaturas e transporte do } \\
\text { pessoal }\end{array}$ & $\mathrm{R} \$ 367.215,98$ & $\mathrm{R} \$ 203.035,20$ & $\mathrm{R} \$ 6.023,27$ & $\mathrm{R} \$ 1.007,41$ & sem dados \\
\hline Deslocação e alimentação & $\mathrm{R} \$ 84.805,29$ & $\mathrm{R} \$ 160.150,73$ & $\mathrm{R} \$ 1.007,02$ & $\mathrm{R} \$ 2.351,09$ & sem dados \\
\hline Aluguel sedes das campanhas & $\mathrm{R} \$ 209.909,68$ & $\mathrm{R} \$ 85.848,55$ & $\mathrm{R} \$ 148,53$ & $\mathrm{R} \$ 2.531,44$ & sem dados \\
\hline Total & $\mathrm{R} \$ 808.456,78$ & $\mathrm{R} \$ 1.168 .970,07$ & $\mathrm{R} \$ 53.608,75$ & $\mathrm{R} \$ 17.986,03$ & sem dados \\
\hline
\end{tabular}

Fonte: Elaboramos baseado nas contas eleitorais da CNE

Tabela 13: Gastos por itens na Legislativa de 2011.

\begin{tabular}{|l|l|l|l|l|l|}
\hline Tipos de & \multicolumn{3}{|l|}{ Partidos } & & \\
\hline Gastos & $\mathrm{PAICV}$ & $\mathrm{MPD}$ & $\mathrm{UCID}$ & $\mathrm{PTS}$ & $\mathrm{PSD}$ \\
\hline Propaganda/Publicidade/animação & $\mathrm{R} \$ 1.593 .321,55$ & $\mathrm{R} \$ 816.090,60$ & $\mathrm{R} \$ 105.821,02$ & $\mathrm{R} \$ 1.178,12$ & sem dados \\
\hline $\begin{array}{l}\text { Aluguel de viaturas e transporte do } \\
\text { pessoal }\end{array}$ & $\mathrm{R} \$ 313.405,65$ & $\mathrm{R} \$ 354.085,41$ & $\mathrm{R} \$ 17.765,35$ & $\mathrm{R} \$ 1.162,36$ & $\mathrm{R} \$ 4.572,37$ \\
\hline Deslocação e alimentação & $\mathrm{R} \$ 213.741,71$ & $\mathrm{R} \$ 85.877,11$ & $\mathrm{R} \$ 6.112,01$ & $\mathrm{R} \$ 2.188,18$ & $\mathrm{R} \$ 1.485,10$ \\
\hline Aluguel sedes das campanhas & $\mathrm{R} \$ 20.220,20$ & $\mathrm{R} \$ 52.414,36$ & $\mathrm{R} \$ 19.979,24$ & $\mathrm{R} \$ 9.487,18$ & sem dados \\
\hline Total & $\mathrm{R} \$ 2.140 .689,11$ & $\mathrm{R} \$ 1.308 .467,48$ & $\mathrm{R} \$ 149.677,62$ & $\mathrm{R} \$ 14.015,84$ & $\mathrm{R} \$ 7.542,57$ \\
\hline
\end{tabular}

Fonte: Elaboramos baseado nas contas eleitorais da CNE

Os dados das duas tabelas acima nos permitem inferir que os partidos políticos precisam de recursos para realizar as suas atividades políticas e eleitorais, principalmente nos períodos eleitorais. Os partidos precisam de recursos para fazer propagandas e, publicidade no intuito de se fazer chegar ao maior número possível de eleitores.

Em geral, os partidos tendem a gastar somas elevadas para penetrar no eleitorado, através dos comícios e festas. Nas eleições passadas com exceção da última legislativa de 2011, os partidos proporcionavam aos seus eleitores atuações de grandes artistas de renome nacional e internacional com o único objetivo de atrair os eleitores e fazer chegar as suas propostas. Entretanto, com a revisão do código eleitoral (2010), estas práticas foram proibidas. Normalmente, no primeiro dia oficial da abertura das campanhas eleitorais os partidos investem no desfile das viaturas com músicas e festas num ambiente bem animado. Como se pode ver, os gastos referentes ao primeiro item "Publicidade, propaganda e animação" são maiores que os outros itens.

Os pequenos partidos queixam-se do dinheiro esbanjado durante o período eleitoral e investem no contato porta-a-porta com os eleitores distribuindo os seus 
programas eleitorais. Fazem também comícios, mas sem atuação de grandes artistas e consequentemente não atraem a grande massa juvenil que aproveita o período eleitoral como sendo época de festas, apesar de ser proibido pelo art.106 ${ }^{\circ}$ do Código Eleitoral ${ }^{57}$. Tendo em conta a composição geográfica de Cabo Verde, país formado por ilhas, de modo que para viajar de uma para outra é necessário o uso de barco ou avião, a campanha porta-a-porta fica severamente prejudicada, dependendo de recursos de cada partido. É comum, os pequenos partidos alegarem não ter recursos para financiar a deslocação dos seus delegados, favorecendo assim a regionalização dos pequenos partidos, um fenômeno considerado presente na política cabo-verdiana.

Outro aspecto a se considerar é que, com a exceção do PRD em 2006, para o qual não encontramos dados e do PSD em 2011, os partidos alugam espaços para fixarem as suas sedes eleitorais no intuito de fazer chegar as suas mensagens até ao eleitorado.

Os dados das duas tabelas acima apresentam certa evidência de uma correlação entre os gastos e o desempenho eleitoral. Nota-se que os dois maiores partidos gastam maiores somas de dinheiro e conseguem eleger um maior número de parlamentares. Em relação aos pequenos partidos, nota-se que a UCID gastou um pouco mais em comparação ao PSD, PRD e PTS e consequentemente conseguiu arrecadar mais votos, elegendo dois deputados nas últimas duas eleições legislativas.

\section{$\underline{\text { 2.3 Financiamentos Indiretos: Tempo de Antena e meios de comunicação social }}$}

Há um último aspecto do financiamento que não pode ser esquecido. Trata-se do financiamento indireto aos partidos políticos através de tempos de antena na rádio e na televisão e que foi criado logo no primeiro governo após a transição política, através do $\operatorname{art}^{\circ} 52$ da lei 1666/IV/94. Zovato diz o seguinte:

"O tema dos meios de comunicação está ligado a dois princípios democráticolegais: equidade e o direito à informação. De um lado, todos os partidos devem ter a oportunidade de apresentar aos cidadãos, através dos meios de comunicação, os seus candidatos, plataformas e programas eleitorais. De outro lado, os eleitores devem ter a possibilidade de informar-se adequadamente sobre

\footnotetext{
${ }^{57}$ É proibido o recurso à atuação de agrupamentos musicais ou de artistas na realização de comícios ou reuniões públicas de campanha eleitoral. (art. 106, alínea 8. Código Eleitora. 2010).
} 
as opções eleitorais e suas propostas, como uma base mínima para realizar uma eleição informada”. (Zovato, 2005:311).

Com a ultima revisão do Código Eleitoral (2010) foi aprovada a seguinte normativa:

Durante os períodos de campanha eleitoral para as eleições legislativas e presidenciais, as estações de rádio e de televisão, independentemente do seu âmbito ou da sua titularidade, facultam, gratuitamente, aos candidatos concorrentes a eleições presidenciais e aos partidos políticos ou coligações concorrentes a eleições legislativas que se apresentam num mínimo de cinco círculos eleitorais, os tempos de antena seguintes: a) $\mathrm{Na}$ rádio, um total de sessenta minutos diários por cada estação, situados entre as doze e as vinte e duas horas, de acordo com as exigências da restante programação; b) Na televisão, um total de vinte minutos diários por cada estação, situados entre as vinte e duas horas, de acordo com as exigências da restante programação. (CE, art. 117).

Observa-se que a única limitação desta legislação é que os partidos devem concorrer no mínimo em cinco círculos eleitorais. "Assim, o partido que se apresente em poucos círculos eleitorais se depara aqui com uma limitação, uma vez que o acesso aos meios de comunicação social durante as campanhas eleitorais é garantido apenas aos partidos com um mínimo de apoio social” (Ramos, 2012:95). Por exemplo, em 2011, o PSD não teve tempo de televisão já que concorria em apenas três círculos.

De acordo com a análise das contas que acabamos de fazer, é possível ver que a hipótese da literatura é forte, considerando que realmente o financiamento importa. Ou seja, partidos que conseguem angariar mais dinheiro obtêm relativamente melhor sucesso eleitoral. Em todas as eleições legislativas realizadas em Cabo Verde, nota-se que os dois grandes partidos conseguiram maiores financiamentos e consequentemente melhor desempenho eleitoral. Os dados mostram que partidos pequenos tiveram um financiamento menor em relação aos dois grandes partidos e consequentemente obtiveram relativamente um menor desempenho, não conseguindo formar uma bancada parlamentar. 


\section{Capitulo 3.}

\section{$\underline{\text { Pequenos Partidos: Sucessos/Insucessos }}$}

Apesar da indiscutível importância do financiamento partidário sobre o sucesso/insucesso dos pequenos partidos e a sua extrema importância na configuração do sistema democrático, entendemos que existe em Cabo Verdes outras variáveis não institucionais que explicam o insucesso e a dificuldade na penetração nos demais círculos eleitorais. Este capítulo apresenta alguns argumentos alternativos que acabam por questionar a centralidade dada pelos pequenos partidos políticos e por alguns analistas políticos ao financiamento público. Consideramos outras explicações de caráter institucional e social que têm impactado sobre o formato da competição bipartidária e o insucesso dos demais partidos. Neste capítulo, pretendemos apresentar algumas variáveis que entendemos serem fundamentais na explicação do insucesso dos pequenos partidos: sistema eleitoral, estratégias de competição eleitoral, preferências eleitorais e principalmente as legislações aprovadas desde a transição política. Analisando as legislações e as atas dos debates parlamentares, pretendemos mostrar que em nenhum momento pensou-se numa terceira força partidária, as leis foram feitas de maneira estratégica pensando no desenvolvimento dos objetivos das duas forças partidárias.

\subsection{O sistema Eleitoral de Cabo Verde}

Nesta seção apresentamos o que consideramos ser uma das principais alternativas para explicar o insucesso dos partidos pequenos. Cabo Verde possui um sistema proporcional de lista fechada, combinado com o método de representação proporcional D'hondt, com baixa magnitude dos distritos eleitorais e a barreira estabelecida (Código eleitoral, art. $416^{\circ}$ ).

Segundo Nicolau e Schmitt (1995) nos sistemas eleitorais de representação proporcional registra-se um número médio de 3,5 partidos parlamentares efetivos. Assim, Costa sinaliza o seguinte: 
"Na realidade, mais exata e particularmente, a combinação dos sistemas de lista fechada com o método D’hondt e com a baixa magnitude dos distritos para a alocação de cadeiras, mostrou ser fundamental na configuração dos sistemas partidário Cabo-Verdiano". (Costa, 2001:75).

Vale a pena ressaltar um aspecto que tem distorcido o sistema eleitoral caboverdiano, isto é, a barreira de 5\% dos votos para que um partido consiga eleger um deputado. No entanto, essa barreira é natural, porque se aplica após o cálculo dos votos. Não está embutida nas legislações, mas verifica-se em todos os círculos eleitorais ao utilizar ao método D’hondt. Entendemos que essa barreira tem dificultado o sucesso dos pequenos partidos, instaurando assim o bipartidarismo, conforme ressalva Évora:

"A preservação da maioria dos círculos eleitorais ${ }^{58}$ de quatro deputados, a atribuição dos mandatos pelo método $D^{\prime}$ Hont (reconhecido pela literatura como a fórmula de representação menos proporcional) e a barreira de 5\%, definiram um sistema partidário e um legislativo com um exemplo de bipartidarismo puro".(Évora, 2013: 238-239).

De acordo com Nicolau (2004), o principal proposito da cláusula de exclusão é dificultar o acesso dos pequenos partidos ao legislativo, contribuindo assim para um parlamento mais estável.

O método D’Hondt é conhecido como sendo o mais desproporcional, ajudando assim sistematicamente os maiores partidos. (Nicolau e Schmitt, 1995). No caso caboverdiano, Évora realça o seguinte:

“A fórmula D’Hondt tem favorecido assim aos dois principais partidos políticos Cabo-verdianos- PAICV e MPD- que se tem revezado no poder, pelo fato daqueles dois partidos conseguirem eleger o maior número de deputados nos dois círculos de maior magnitude eleitoral e controlam assim o legislativo Cabo-Verdiano". (Évora, 2009:131)

Em relação ao desenho dos círculos eleitorais ${ }^{59}$, o sistema eleitoral caboverdiano afigura-se pelo domínio de círculos de pequena dimensão ${ }^{60}$ (entre 2 e 4

\footnotetext{
${ }^{58}$ A expressão círculos eleitoral é usada como sinonimo de distrito eleitoral.

59 Nas eleições legislativas de 1991 e 1995 foram constituídos 19 círculos eleitorais sendo 16 no território nacional (Praia, São Vicente, Santa Catarina, São Nicolau, Tarrafal, São Filipe, Santa Cruz, Porto
} 
deputados) que nas cinco eleições elegeram respectivamente, 25, 41, 39, 40 e 17 do total de deputados (ver gráfico abaixo). Quanto aos círculos eleitorais ${ }^{61}$ de média dimensão (entre 5-7 deputados), após as eleições de 1991 verifica-se uma diminuição drástica do número de mandatos que podem eleger, mas em 2011 representantes oriundos dos círculos médios haviam sido 11 deputados $\mathrm{O}$ dado mais interessante é o que diz respeito aos distritos grandes. Apenas dois círculos eleitorais- Praia e São Vicente elegeram mais de 10 deputados, sendo que essa proporção vem aumentando ao longo do tempo (Sanches, 2013). Entretanto, a reforma eleitoral de 1 de Dezembro de 2010 volta a rever o desenho dos círculos, em função dos resultados dos Censo. Os círculos eleitorais foram reduzidos de 20 para 13, um por ilha. , com exceção a Ilha de Santiago, que foi dividida em dois grandes círculos: Santiago Norte e Santiago Sul. Assim, na última eleição os três círculos grandes foram responsáveis por eleger 44 deputados, número esse maior que a metade do total (72) dos deputados que compõem a Assembleia Nacional de Cabo Verde.

Novo, Ribeira Grande, Paul, Sal, Boa Vista, São Domingos, Mosteiros, Brava, Maio) e três no estrangeiro (África, América, Europa/Resto do mundo). Na eleição legislativa de 1991, a assembleia nacional era constituída por 79 deputados. Com a revisão da legislação eleitoral em 1994, atribuiram-se dois mandatos para cada circulo eleitoral no estrangeiro, e foi reduzido o número de deputados de 79 para 72 (art. 3910 Lei Eleitoral de 1999). Com a criação de novo município (São Miguel Arcanjo) em 1997, deu origem a um novo círculo eleitoral, sendo assim, as eleições legislativas de 2001 e 2006 contaram com 20 círculos eleitorais, elegendo 72 deputados, conforme mostra a tabela acima

${ }^{60}$ Sanches (2013:264).

${ }^{61}$ Ao longo da dissertação, iremos utilizar a denominação de círculos eleitorais, que corresponde ao mesmo que distritos eleitorais. 
Gráfico 8. Dimensão dos círculos eleitorais.

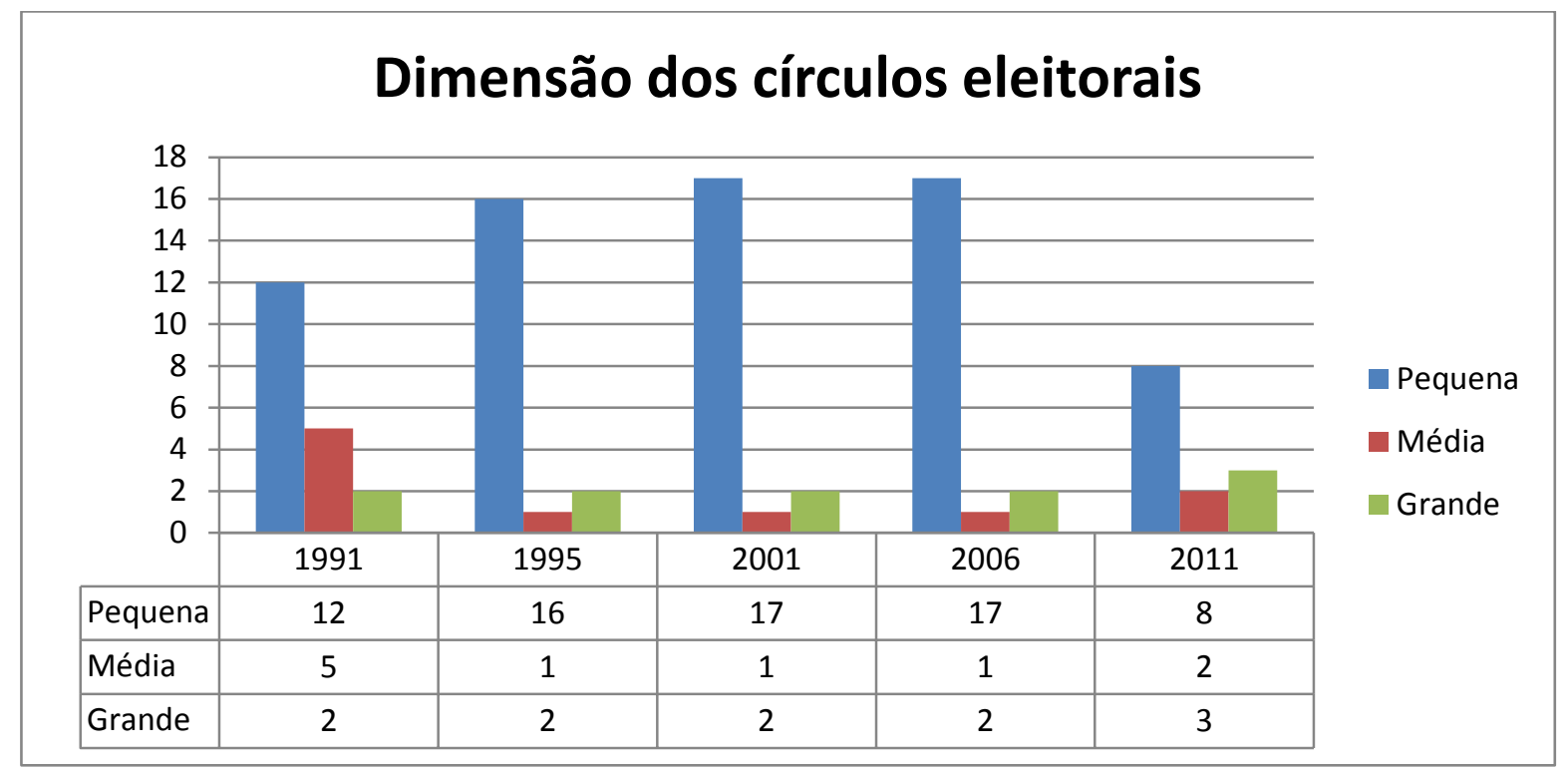

Fonte: Elaborado a partir de Sanches, 2013.

Gráfico 9. Distribuição dos mandatos por círculos.

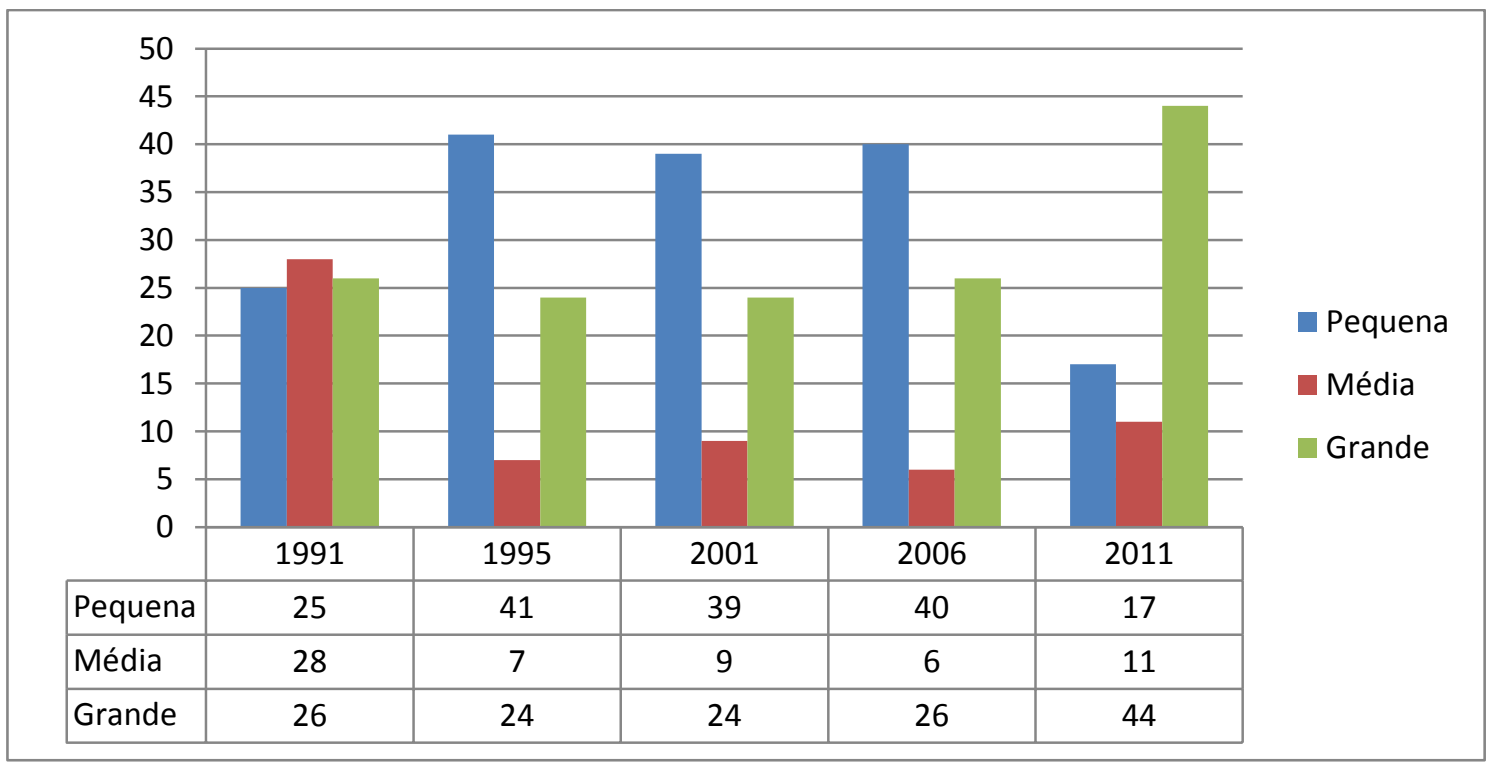

Fonte: Elaborado a partir de Sanches, 2013.

Nota: Pequena (elege até quatro deputados). Médio (elege 5-9 deputados), Grande (elege + 10 deputados $)^{62}$.

${ }^{62}$ Sanches, 2013:264. 
Entre os próprios partidos há grande debate sobre o tema do tamanho dos círculos eleitorais. Analisamos o debate da aprovação do código eleitoral de 1999, que ficou marcado pelas discussões acerca da proporcionalidade dos círculos eleitorais. A então oposição (PAICV e PCD) argumentou que havia falhas no sistema proporcional, afirmando que o sistema produzia um efeito proporcional reduzido muito devido à existência de círculos pequenos que elegem entre um e dois deputados. A oposição entendeu que devido à configuração dos círculos eleitorais o sistema proporcional teria produzido um resultado inverso ao que era suposto produzir. Entretanto, para corrigir o problema da representatividade, e consequentemente ter maior representação possível de todas as forças politicas, incluindo os pequenos partidos, a oposição sugeriu a criação de círculo-ilha, em que cada ilha passaria a constituir um círculo eleitoral. Lembrando que a própria Constituição de Cabo Verde apresenta o sistema como sendo pluripartidário, assim a solução apresentada passaria por constituir círculos grandes de modo a evitar o bipartidarismo. Assim o bipartidarismo nunca deveria ser o resultado da aplicação do sistema proporcional, como defendido para o PCD.

O problema da representatividade dos pequenos partidos é uma questão pouco debatida no parlamento cabo-verdiano. No debate da aprovação do código eleitoral (1999), o partido com maioria no parlamento (MPD) chegou a afirmar que todos deveriam estar preocupados com a solução governativa para o país, isto é, um sistema que permite uma solução em termos de maioria para governar, deixando de lado o problema dos pequenos partidos, que não é o problema da população Cabo-verdiana. Assim o melhor sistema era aquele que permitisse uma solução governativa com uma maioria para governar. Consideramos que isso foi um golpe duro para os pequenos partidos, visto que o partido no poder (MPD) tinha maioria qualificada no parlamento, que lhe permitiria aprovar ou retificar qualquer lei. Os partidos da oposição entenderam que a transformação dos círculos pequenos em círculos-ilha, daria mais oportunidades para os pequenos partidos ascenderem e conseguirem um lugar no parlamento caboverdiano.

Para observar melhor a influência do tamanho do círculo eleitoral, vale a pena desagregar os dados e ver a distribuição das cadeiras por partido levando em conta os círculos eleitorais. A tabela abaixo apresenta o número dos deputados eleitos por circulo eleitoral nas eleições legislativas de 1991-2006, antes da reforma de 2010. 
Tabela 14. Eleitos por circulo eleitoral nas eleições de 1991-2006.

\begin{tabular}{|c|c|c|c|c|c|c|c|c|c|c|c|c|c|c|c|}
\hline Círculos & 1991 & & & 1995 & & & & 2001 & & & & 2006 & & & \\
\hline & MPD & PAICV & Total & MPD & PAICV & PCD & Total & MPD & PAICV & ADM & Total & MPD & PAICV & UCID & Total \\
\hline Praia & 9 & 5 & 14 & 8 & 4 & 1 & 13 & 5 & 8 & 1 & 14 & 7 & 8 & 0 & 15 \\
\hline São Vicente & 10 & 2 & 12 & 8 & 3 & 0 & 11 & 4 & 6 & 1 & 11 & 4 & 5 & 2 & 11 \\
\hline $\begin{array}{l}\text { Santa } \\
\text { Catarina }\end{array}$ & 7 & 1 & 8 & 6 & 1 & 0 & 7 & 3 & 4 & 0 & 7 & 3 & 3 & 0 & 6 \\
\hline São Nicolau & 4 & 1 & 5 & 2 & 0 & 0 & 2 & 1 & 1 & 0 & 2 & 1 & 1 & 0 & 2 \\
\hline Tarrafal & 4 & 1 & 5 & 3 & 1 & 0 & 4 & 1 & 1 & 0 & 2 & 1 & 1 & 0 & 2 \\
\hline São Filipe & 2 & 3 & 5 & 1 & 3 & 0 & 4 & 1 & 2 & 0 & 3 & 1 & 3 & 0 & 4 \\
\hline Santa Cruz & 4 & 1 & 5 & 4 & 0 & 0 & 4 & 2 & 2 & 0 & 4 & 1 & 3 & 0 & 4 \\
\hline Porto Novo & 4 & 0 & 4 & 2 & 1 & 0 & 3 & 2 & 1 & 0 & 3 & 1 & 2 & 0 & 3 \\
\hline $\begin{array}{l}\text { Ribeira } \\
\text { Grande }\end{array}$ & 4 & 0 & 4 & 4 & 0 & 0 & 4 & 2 & 3 & 0 & 4 & 2 & 1 & 0 & 3 \\
\hline Paul & 2 & 0 & 2 & 2 & 0 & 0 & 2 & 1 & 1 & 0 & 2 & 1 & 1 & 0 & 2 \\
\hline Sal & 1 & 1 & 2 & 1 & 1 & 0 & 2 & 1 & 1 & 0 & 2 & 1 & 1 & 0 & 2 \\
\hline Boa Vista & 0 & 2 & 2 & 1 & 1 & 0 & 2 & 1 & 1 & 0 & 2 & 1 & 1 & 0 & 2 \\
\hline $\begin{array}{l}\text { São } \\
\text { Domingos }\end{array}$ & 2 & 0 & 2 & 2 & 0 & 0 & 2 & 1 & 1 & 0 & 2 & 1 & 1 & 0 & 2 \\
\hline Mosteiros & 0 & 2 & 2 & 1 & 1 & 0 & 2 & 1 & 1 & 0 & 2 & 0 & 2 & 0 & 2 \\
\hline Brava & 1 & 1 & 2 & 1 & 1 & 0 & 2 & 1 & 1 & 0 & 2 & 1 & 1 & 0 & 2 \\
\hline Maio & 1 & 1 & 2 & 1 & 1 & 0 & 2 & 1 & 1 & 0 & 2 & 1 & 1 & 0 & 2 \\
\hline $\begin{array}{l}\text { Paises } \\
\text { Africanos }\end{array}$ & 0 & 1 & 1 & 1 & 1 & 0 & 2 & 1 & 1 & 0 & 2 & 0 & 2 & 0 & 2 \\
\hline P.Americanos & 0 & 1 & 1 & 1 & 1 & 0 & 2 & 0 & 2 & 0 & 2 & 0 & 2 & 0 & 2 \\
\hline $\begin{array}{l}\text { Europa/resto } \\
\text { m. }\end{array}$ & 1 & 0 & 1 & 1 & 1 & 0 & 2 & 0 & 2 & 0 & 2 & 1 & 1 & 0 & 2 \\
\hline São Miguel & & & & & & & & 1 & 1 & 0 & 2 & 1 & 1 & 0 & 2 \\
\hline Total & 56 & 23 & 79 & 50 & 21 & 1 & 72 & 30 & 40 & 2 & 72 & 29 & 41 & 2 & 72 \\
\hline
\end{tabular}

Fonte: Elaborado a partir dos resultados de eleições da CNE. Costa, 2003; Afrosondagem, 2007. ${ }^{63}$ ADM (Aliança Democrática para Mudança) foi uma coligação formada pela UCID, PCD e PTS.

Os dados da tabela acima nos permitem ver o enquadramento e sucessos dos partidos políticos cabo-verdianos ao longo das quatro eleições legislativas realizadas considerando o tamanho dos distritos. É evidente que os dois grandes partidos (PAICV, MPD) tiveram sucessos em todos os distritos desde a transição política, em todas as eleições. Como visto anteriormente, entendemos que talvez esse domínio se explique pelo contexto do surgimento que passou pelos dois marcos históricos da politica caboverdiana. O PAICV é visto como o partido da independência, tendo em conta que nasceu no seio do PAIGC (partido que lutou e negociou a independência de GuinéBissau e Cabo Verde). Entretanto o MPD é visto como partido que trouxe a democracia. Ele nasceu no contexto da transição política, num momento em que muitos

\footnotetext{
${ }^{63}$ Aliança Democrática para Mudança (ADM) foi uma coligação formada pela UCID, PCD e PTS.
} 
consideravam que a população já estava cansada do partido único e aspirava a uma mudança. Isso fez com que o MPD levasse os créditos necessários.

O que interessa observar, porém, é o desempenho dos pequenos partidos. Estes conseguem eleger deputados apenas nos grandes círculos de Praia e São Vicente.

Na eleição legislativa de 1995, o PCD, que foi fruto de uma cisão dentro do MPD, conseguiu eleger um deputado em Praia. Em 2001, o ADM conseguiu eleger dois deputados em Praia e São Vicente, vindo de uma coligação de três partidos. A UCID conseguiu eleger dois deputados na legislativa de 2006 em São Vicente. Em geral os dados enfatizam o desempenho regional dos partidos.

Até agora, os dados confirmam aquilo que era previsto pela teoria: o partido pequeno tem maiores chance de vitória em círculos grandes. Com a ultima revisão do desenho de tamanho dos círculos, nos permite fazer algumas considerações sobre a suposta relação entre o tamanho do círculo e o desempenho eleitoral dos partidos. A tabela a seguir mostra a nova reconfiguração dos círculos e o relativo desempenho dos partidos.

Tabela 15. Eleitos por circulo eleitoral na eleição legislativa de 2011.

\begin{tabular}{|c|c|c|c|c|c|c|}
\hline & & & & Deputados I & eitos por & artidos \\
\hline Círculos Eleitorais & $\begin{array}{l}\text { Deputados a } \\
\text { eleger }\end{array}$ & PAICV & MPD & UCID & PSD & PTS \\
\hline Santiago Sul & 19 & 11 & 8 & 0 & 0 & 0 \\
\hline Santiago Norte & 14 & 8 & 6 & 0 & 0 & 0 \\
\hline São Vicente & 11 & 5 & 4 & 2 & 0 & 0 \\
\hline Santo Antão & 6 & 3 & 3 & 0 & 0 & 0 \\
\hline $\begin{array}{l}\text { Europa/resto } \\
\text { mundo }\end{array}$ & 2 & 1 & 1 & 0 & 0 & 0 \\
\hline Fogo & 5 & 3 & 2 & 0 & 0 & 0 \\
\hline Sal & 3 & 1 & 2 & 0 & 0 & 0 \\
\hline São Nicolau & 2 & 1 & 1 & 0 & 0 & 0 \\
\hline Américas & 2 & 1 & 1 & 0 & 0 & 0 \\
\hline Boa vista & 2 & 1 & 1 & 0 & 0 & 0 \\
\hline África & 2 & 1 & 1 & 0 & 0 & 0 \\
\hline Maio & 2 & 1 & 1 & 0 & 0 & 0 \\
\hline Brava & 2 & 1 & 1 & 0 & 0 & 0 \\
\hline Total & 72 & 37 & 33 & 2 & 0 & 0 \\
\hline
\end{tabular}

Fonte: Elaboração própria, baseando nos dados dos boletins oficiais. 
Os dados acima mostram algo diferente. Observa-se que houve uma diminuição de pequenos círculos que elegem até dois deputados e que favorecia os dois grandes partidos que já têm uma base forte no eleitorado. Um dos primeiros aspectos a ter em conta é que apesar dessa diminuição de círculos pequenos, os pequenos partidos não foram bem-sucedidos, repetindo o mesmo resultado das eleições legislativas anteriores. Nos dois maiores círculos eleitorais de Cabo-Verde, Santiago Sul e Santiago Norte, que agora elegem quase a metade do total dos deputados, os pequenos partidos não conseguiram eleger quaisquer deputados e os dois grandes partidos dominaram novamente, o cenário político. A UCID foi o único partido concorrente a eleger dois deputados no círculo eleitoral de São Vicente, mas isso se deve ao fato de que é nessa área que o partido desenvolve sua atividade, tendo uma base eleitoral bem forte (Ramos, 2012).

Um outro dado alimenta a suspeita de que a variável tamanho do distrito não seja tão relevante para explicar o insucesso dos partidos pequenos. A tabela a seguir mostra a magnitude dos grandes círculos eleitorais e os respetivos números de votos, tendo como hipótese de que círculos grandes favorecerem os pequenos partidos políticos.

Tabela 16. Magnitude e numero dos votos nos grandes círculos na eleição legislativa de 2011.

\begin{tabular}{|l|l|l|r|l|r|r|r|}
\hline & & & \multicolumn{2}{|l|}{ Numero dos votos } & & \\
\hline $\begin{array}{l}\text { Círculos } \\
\text { Eleitorais }\end{array}$ & Magnitude & $\begin{array}{l}\text { Numero dos } \\
\text { eleitores }\end{array}$ & PAICV & MPD & UCID & PSD & \multicolumn{1}{|l|}{ PTS } \\
\hline Santiago Sul & $\begin{array}{l}\text { Grande } \\
(19)\end{array}$ & 78.751 & 33.754 & 27.116 & $\mathbf{9 7 6}$ & $\mathbf{1 6 3}$ & 0 \\
\hline Santiago Norte & $\begin{array}{l}\text { Grande } \\
(14)\end{array}$ & 58.158 & 19.793 & 25.196 & $\mathbf{5 6 5}$ & $\mathbf{1 9 3}$ & $\mathbf{2 8 8}$ \\
\hline São Vicente & $\begin{array}{l}\text { Grande } \\
(1)\end{array}$ & 45.802 & 14.835 & 11.541 & $\mathbf{6 . 2 9 7}$ & $\mathbf{7 3}$ & $\mathbf{5 0 4}$ \\
\hline
\end{tabular}

Fonte: Elaboração própria, baseado nos dados dos boletins oficiais.

Realizando um cálculo básico, dividimos o número de eleitores pela magnitude de distrito. Isso revela o valor relativo ao peso eleitoral de cada cadeira. No círculo eleitoral de Santiago Sul, que elege 19 dos 72 deputados, cada cadeira representa aproximadamente 4.144 votos. Já no segundo círculo maior que é o Santiago Norte, uma cadeira representa aproximadamente 4.154 votos, enquanto que no círculo eleitoral de São Vicente este valor é de aproximadamente 4.163. Como se observa da tabela, o 
numero de eleitores que apoiam os pequenos partidos nestes círculos é baixo ou até nulo como no caso do PTS. Estes números são interessantes já que indicam que os pequenos partidos, mesmos nos grandes distritos, não conseguiram apoio eleitoral para eleger deputados.

Um ulterior dado nos ajuda a entender a reduzida importância do elemento relativo ao tamanho dos círculos para explicar o bipartidarismo em cabo Verde. Trata-se das estratégias de campanha dos partidos pequenos.

É de se esperar que os pequenos partidos lancem candidatos nos distritos de magnitude maior, onde de fato as chances de sucesso para seus candidatos deveriam ser maiores. Interessante notar o posicionamento do líder da UCID António Monteiro que afirmou em entrevista recente a importância para o partido de se concentrar nas disputas nos círculos maiores, "porque quanto maior for o espectro, maiores probabilidades têm de eleger um candidato" ${ }^{64}$. Essa estratégia faz com que o partido seja pouco conhecido nas demais ilhas. Como admite o próprio líder da UCID, o partido "não tem muita visibilidade fora de São Vicente" 65 .

Assim como mostram as tabelas 17 e 18 , os pequenos partidos tendem a lançar candidatos nos círculos grandes, onde têm maior probabilidade de fazer eleger deputados. Apesar de se concentrarem nos círculos onde supostamente teriam mais chance de sucesso, eles não conseguiram eleger deputados suficientes para obterem subsídio do fundo partidário.

Tabela 17. Círculos onde os pequenos partidos lançam candidatos na eleição legislativa de 2011.

\begin{tabular}{|l|l|l|l|l|l|l|l|l|l|}
\hline $\begin{array}{l}\text { Círculos } \\
\text { eleitorais }\end{array}$ & \multicolumn{1}{|c|}{$\mathbf{1 9 9 5}$} & & & $\mathbf{2 0 0 1}$ & & & $\mathbf{2 0 0 6}$ & & \\
\hline & PCD & $\begin{array}{l}\text { UCI } \\
\text { D }\end{array}$ & $\begin{array}{l}\text { PS } \\
\text { D }\end{array}$ & ADM & $\begin{array}{l}\text { PR } \\
\text { D }\end{array}$ & $\begin{array}{l}\text { PS } \\
\text { D }\end{array}$ & PRD & $\begin{array}{l}\text { PS } \\
\text { D }\end{array}$ & UCID \\
\hline Praia & $\begin{array}{l}\mathrm{x}-1 \\
\text { dep }\end{array}$ & $\mathrm{x}$ & $\mathrm{x}$ & $\begin{array}{l}\mathrm{x}-1 \\
\mathrm{dep}\end{array}$ & $\mathrm{x}$ & $\mathrm{x}$ & $\mathrm{x}$ & $\mathrm{x}$ & \\
\hline São Vicente & $\mathrm{x}$ & $\mathrm{x}$ & $\mathrm{x}$ & $\begin{array}{l}\mathrm{x}-1 \\
\mathrm{dep}\end{array}$ & $\mathrm{x}$ & $\mathrm{x}$ & $\mathrm{x}$ & & $\mathrm{x}-2$ dep \\
\hline $\begin{array}{l}\text { Santa } \\
\text { Catarina }\end{array}$ & $\mathrm{x}$ & $\mathrm{x}$ & $\mathrm{x}$ & $\mathrm{x}$ & $\mathrm{x}$ & $\mathrm{x}$ & $\mathrm{x}$ & & \\
\hline São Nicolau & $\mathrm{x}$ & & & $\mathrm{x}$ & $\mathrm{x}$ & & & & \\
\hline
\end{tabular}

\footnotetext{
${ }^{64}$ Entrevista ao Jorna A semana do dia 16/05/2014

${ }^{65}$ idem
} 


\begin{tabular}{|c|c|c|c|c|c|c|c|c|c|}
\hline Tarrafal & $\mathrm{x}$ & $\mathrm{x}$ & $\mathrm{x}$ & $\mathrm{x}$ & $\mathrm{x}$ & $\mathrm{x}$ & $\mathrm{x}$ & & \\
\hline São Filipe & $\mathrm{x}$ & $\mathrm{x}$ & $\mathrm{x}$ & $\mathrm{X}$ & $\mathrm{x}$ & & & & \\
\hline Santa Cruz & $\mathrm{x}$ & $\mathrm{x}$ & $\mathrm{x}$ & $\mathrm{X}$ & $\mathrm{x}$ & $\mathrm{x}$ & $\mathrm{X}$ & & \\
\hline Porto Novo & $\mathrm{x}$ & & & $\mathrm{x}$ & $\mathrm{x}$ & $\mathrm{x}$ & $\mathrm{x}$ & & \\
\hline $\begin{array}{l}\text { Ribeira } \\
\text { Grande }\end{array}$ & $\mathrm{x}$ & $\mathrm{x}$ & & $\mathrm{X}$ & $\mathrm{X}$ & $\mathrm{x}$ & & & \\
\hline Paul & $\mathrm{X}$ & $\mathrm{x}$ & & $\mathrm{X}$ & $\mathrm{x}$ & & & & \\
\hline Sal & $\mathrm{x}$ & & & $\mathrm{X}$ & $\mathrm{x}$ & $\mathrm{x}$ & & & \\
\hline Boa Vista & $\mathrm{x}$ & $\mathrm{X}$ & & $\mathrm{X}$ & $\mathrm{x}$ & $\mathrm{x}$ & & & \\
\hline São Domingos & $\mathrm{x}$ & $\mathrm{x}$ & $\mathrm{x}$ & $\mathrm{X}$ & $\mathrm{x}$ & $\mathrm{x}$ & $\mathrm{x}$ & & \\
\hline Mosteiros & $\mathrm{x}$ & & & $\mathrm{X}$ & $\mathrm{x}$ & & $\mathrm{x}$ & & \\
\hline Brava & $\mathrm{x}$ & & & $\mathrm{X}$ & $\mathrm{x}$ & & & & \\
\hline Maio & $\mathrm{x}$ & & & $\mathrm{x}$ & $\mathrm{x}$ & & & $\mathrm{x}$ & \\
\hline $\begin{array}{l}\text { Paises } \\
\text { Africanos }\end{array}$ & $\mathrm{x}$ & & & $\mathrm{x}$ & $\mathrm{x}$ & $\mathrm{x}$ & & & \\
\hline P.Americanos & $\mathrm{x}$ & $\mathrm{x}$ & & $\mathrm{x}$ & $\mathrm{x}$ & $\mathrm{x}$ & & $\mathrm{x}$ & \\
\hline $\begin{array}{l}\text { Europa/resto } \\
\text { m. }\end{array}$ & $\mathrm{x}$ & $\mathrm{x}$ & & $\mathrm{x}$ & $\mathrm{x}$ & $\mathrm{x}$ & & $\mathrm{X}$ & \\
\hline São Miguel & & & & $\mathrm{x}$ & $\mathrm{x}$ & $\mathrm{x}$ & $\mathrm{x}$ & $x^{66}$ & \\
\hline Total & 1 dep. & & & 2 dep. & & & & & 2 dep. \\
\hline
\end{tabular}

Fonte: Elaboração própria, baseado nos dados dos boletins oficiais.

Nota: X- locais onde os pequenos partidos lançam candidatos.

Em 1995 e 2001, o PCD $^{67}$, concorreu em todos os círculos eleitorais, sendo em 2001 no quadro da coligação Aliança Democrática para Mudança (ADM). O nível de votos que o PCD alcançou nos dois maiores círculos eleitorais do país, nomeadamente Praia e São Vicente, não lhe permitiu eleger mais do que um deputado. O mesmo podese dizer em relação ao PTS que em 2001 elegeu um único deputado no âmbito da coligação eleitoral ADM. O PRD, apesar de lançar candidatos em todos os círculos eleitorais nas legislativas de 2001, não elegeu qualquer deputado. A UCID, na eleição legislativa de 2006, concentrou os seus esforços exclusivamente em São Vicente, elegendo dois deputados.

Para 2011, nota-se que os pequenos partidos continuaram a apostar nos grandes círculos. A UCID reelegeu os dois deputados no círculo eleitoral de São Vicente. Apesar do PSD e PTS lançarem candidatos em alguns círculos eleitorais, eles não conseguiram eleger nenhum deputado.

\footnotetext{
${ }^{67}$ Partido de Convergênia Democratica
} 
Até a última eleição legislativa, a UCID não tinha diretórios políticos em todos os círculos eleitorais. Porém, contava com uma base eleitoral bem forte em São Vicente aonde tinha como objetivo conseguir eleger quatro deputados.

Em geral, a suspeita é que os pequenos partidos, mesmo competindo em círculos eleitorais que lhe conferem mais chances de eleger representantes, não conseguem ser bem-sucedidos em virtude da escassa penetração territorial. Isso chama em causa outras explicações que não remetem ao formato do sistema eleitoral. A seguir introduzimos o tema do apoio por parte da população e de suas preferências eleitorais.

\section{2 - Preferências Eleitorais}

Analisamos as preferências eleitorais através das quatro rodadas (2002, 2005, 2008 e 2011) de pesquisa de opinião realizada pelo Afrobarometer. A tabela a baixo sintetiza a proximidade dos entrevistados com os partidos durante as quatro rodadas (2002, 2005, 2008 e 2011) de pesquisa realizada pelo Afrobarometer.

Tabela 18: “Sente-se próximo algum partido político”- Cabo Verde.

\begin{tabular}{llllll}
\hline Sente-se próximo algum partido político & 2002 & 2005 & 2008 & 2011 \\
\hline $\begin{array}{l}\text { Não (NÃO SE SENTE próximo de nenhum partido } \\
\text { Politico) }\end{array}$ & 50 & 45 & 30 & 37 \\
Sim (sente-se próximo de um partido político) & 48 & 52 & 63 & 62 \\
Não Sabe & 1 & 3 & 4 & \\
Total & 100 & 100 & 100 & 100 \\
\hline
\end{tabular}

Fonte: Elaborado a partir de base dados Afrobarometer.

Os dados da tabela revelam uma percentagem alta da proximidade das pessoas em relação aos partidos políticos. Mais importante do que isso é constatar que essa proximidade vem crescendo ao longo do tempo. Em 2002 apenas 48\% das pessoas se identificaram com algum partido político, sendo que a maioria (50\%) não se identificava com quaisquer partidos. Entretanto, as pessoas se identificam fortemente com algum partido político, em valor que se manteve alto em 2008, e se confirmou em 
2011. Esses dados não distinguem o grau de satisfação com relação aos próprios partidos. Afinal, pode ser que a idenficação seja direcionada para os pequenos partidos em proporção maior do que a que os resultados eleitorais mostram. Porém, ao analisar a pergunta do Afrobarometer relativa a quais são os partidos com os quais os entrevistados se identificam notamos que a maioria se sente próxima aos dois grandes partidos políticos (MPD, PAICV), conforme sintetiza a tabela que se segue.

Tabela 19: "Que Partido é esse”-

\begin{tabular}{|l|l|l|l|l|}
\hline Que partido é esse & 2002 & 2005 & 2008 & 2011 \\
\hline MPD- Movimento Para Democracia & 47 & 51 & 28 & 45 \\
\hline PAICV- Partido Africano Independência de Cabo Verde & 45 & 46 & 37 & 51 \\
\hline PCD- Partido de Convergência Democrática & 3 & 1 & 0 & 0 \\
\hline $\begin{array}{l}\text { UCID Independente e } \\
\text { Democrática União Cabo-Verdiana }\end{array}$ & 1 & 0 & 3 & 3 \\
\hline Outros NS/NR & 1 & 1 & 0 & 0 \\
\hline Não Aplicado & 3 & 1 & 1 & 0 \\
\hline Total & --- & ---- & 37 & ---- \\
\hline
\end{tabular}

Fonte: Elaborado a partir de base dados Afrobarometer

Os dados dessa tabela confirmam o domínio dos dois grandes partidos (MPD e PAICV) não apenas do ponto de vista eleitoral, mas em termos de preferências políticas. Ao longo das quatro rodadas de pesquisa, os pequenos partidos não conseguiram se afirmar e tiveram baixas ou nulas preferências dos eleitores, sinalizando apenas uma alternância de preferências entre os dois grandes partidos. Nota-se que a UCID conseguiu conquistar as preferências a partir da terceira rodada (2008), altura em que tinha conseguido eleger dois deputados na legislativa de 2006. Acreditamos que esse é um dos indicadores que nos permitem afirmar que a UCID não tem o apoio da população. As pessoas não se identificam com a UCID ou outras forças minoritárias. A tabela a seguir apresenta os dados da mesma pergunta referida a cima, mais em comparação com alguns países africanos para a quinta rodada do Afrobarometro (2011). 
Tabela 20: Sente próximo a alguém partido político em particular?

\begin{tabular}{|l|c|}
\hline Países & Sente-se próximo a algum partido? \\
\hline Moçambique & $\mathbf{7 1}$ \\
\hline Cabo Verde & $\mathbf{6 2}$ \\
\hline Senegal & $\mathbf{6 0}$ \\
\hline África do Sul & $\mathbf{6 0}$ \\
\hline Gana & $\mathbf{5 9}$ \\
\hline Guiné-Konakry & $\mathbf{5 7}$ \\
\hline Nigéria & 45 \\
\hline Argélia & 42 \\
\hline Benin & 38 \\
\hline
\end{tabular}

Os dados da tabela acima mostram que geralmente as pessoas se identificam com algum partido político, porém existem países em que não acontece tal fato. Cabo Verde apresenta um percentual alto (62\%) em comparação com outros países africanos, e apenas Moçambique apresenta um percentual superior (71\%). Senegal e África do Sul apresentam um mesmo percentual $(60 \%)$ de entrevistados que se declarou sentir próximo a algum partido político. Curioso notar que em três países (Argélia, Benin e Nigéria) as pessoas não se sentem próximas a quaisquer partidos. Esses três países apresentam um percentual bem baixo de entrevistados que se declaram sentir próximo a algum partido político, conforme mostra a tabela acima.

Em Cabo Verde as pessoas não transferem as preferências a um terceiro partido, mesmo em períodos não eleitorais, tendo em conta os resultados da tabela abaixo. Abaixo estão às respostas, nas duas rodadas $(2008,2011)$ à seguinte pergunta: "Se as eleições legislativas fossem amanhã em qual partido votarias?”. 
Tabela 21: - Intenções de voto.

\begin{tabular}{|l|l|l|}
\hline Qual Partido & 2008 & 2011 \\
\hline MPD- Movimento Para Democracia & 35 & 36 \\
\hline PAICV- Partido Africano Independência de Cabo Verde & 30 & 35 \\
\hline PCD- Partido de Convergência Democrática & 0 & 0 \\
\hline $\begin{array}{l}\text { UCID - União Cabo-Verdiana Independente e } \\
\text { Democrática }\end{array}$ & 2 & 4 \\
\hline PRD- Partido da Renovação Democrática & 0 & 0 \\
\hline Não Vota & 5 & 14 \\
\hline Recusa em responder & 17 & \\
\hline Não sabe & 10 & 11 \\
\hline Total & 100 & 100 \\
\hline
\end{tabular}

Fonte: Elaborado a partir de base dados Afrobarometer

Não há duvida que existe uma proximidade bem clara dos entrevistados com os dois grandes partidos. Os dois grandes partidos obtêm maiores percentagens de intenção de voto. Curioso notar que os demais entrevistados não têm intenção de votar na UCID já que apenas 2\% em 2008 e 3\% em 2011 declaram o seu apoio à UCID. Na quarta rodada (2008) 17\% dos respondentes se recusaram em responder, e 10\% não sabiam, mas, mesmo assim, não falaram em votar num terceiro partido. Na quinta rodada, em 2011 repetiu-se o mesmo cenário. Fica claro nessa primeira análise que as pessoas não transferem sua preferência a terceiros partidos, confirmando assim a dificuldade do partido em penetrar nos círculos eleitorais e ter o apoio dos eleitores.

Estes dados abrem a possibilidade de pensarmos em algumas hipóteses alternativas para além das variáveis institucionais. A seguir, iremos analisar alguns fatores que consideramos ser vantajosos para os grandes partidos e que condicionam o insucesso dos pequenos partidos. Dentre elas temos o modo como são feitas as eleições e formadas as preferências eleitorais, mostrando que as estratégias de campanha são uma condição habitual para entendermos a dinâmica competitiva em Cabo Verde. 


\section{$\underline{\text { 3.3 Eleicões e Estratégias de Campanha }}$}

Aprendeemos no segundo capítulo que durante os períodos eleitorais os partidos políticos tendem a gastar muito dinheiro no sentido de fazer chegar até ao eleitorado a sua plataforma eleitoral. Suspeita-se da existência de compra de votos em Cabo Verde, apesar de essa prática ser proibida de acordo com o art.106 ${ }^{068}$ do código eleitoral. Entretanto, não existe ainda um estudo aprofundado e dedicado exclusivamente sobre compra de votos em Cabo Verde. Em vários jornais locais abundam noticias em tal sentido. Assim, por exemplo, vale a descrição do processo eleitoral como descrita pelo Jornal A Nação:

"A campanha eleitoral em Cabo Verde tem sido vista também como oportunidade de pequenos negócios. Tendo as vendedeiras ambulantes, aproveitado dessa época para massificaram as suas vendas. Também os técnicos de som, empresas ligas à área, e os proprietários de carros, aproveitam essa época para faturarem. Nesse período de campanha eleitoral, há dinheiro para tudo, inclusive parra oferta de sacos de cimentos, feros para a construção civil, eletrodomésticos, entre outros brindes. (In Jornal, "A Nação" n ${ }^{\circ} 178$, fevereiro de 2011).

Em geral, emerge com clareza destes relatos que os partidos contratam grupos de jovens para acompanhá-los nas campanhas porta-a-porta e para convencer os outros jovens a ingressar no partido em questão. Por isso é compreensível o resultado da quinta rodada (2011) da pesquisa do Afrobarometer, na qual há a seguinte pergunta: "Pensando na ultima eleição legislativa de 2011, já trabalhou para um candidato ou partido?" Segundo a pesquisa, $88 \%$ dos respondentes já trabalharam para um determinado partido político. Nota-se que $71 \%$ dos entrevistados já tentaram convencer outras pessoas a votar num determinado candidato.

Entendemos que as campanhas porta-a-porta se tornam eficientes porque em Cabo Verde as pessoas não participam em massa nos grandes comícios. Apenas 53\% participaram comparando com Moçambique em que 64\% das pessoas participam nas

\footnotetext{
68 É proibido doar, oferecer ou entregar, diretamente ou por intermédio de terceiro, dinheiro ou quaisquer mercadorias, bens ou artigos que não sejam considerados simples enfeites ou adereços. (art.106. CE).
} 
campanhas eleitorais e nas atividades dos partidos políticos, de acordo com os dados da quinta rodada da Afrobarometer (2011) ${ }^{69}$.

Outra questão que consideramos ter favorecido os grandes partidos sobre os pequenos é a estratégia da votação por parte dos eleitores. Muitas vezes os eleitores votam esperando algo em troca. Ouvem-se muito em períodos eleitorais eleitores a perguntarem aos partidários, “O que você me dá para votar em você?”. Acreditamos que essa estratégia favorece e tem favorecido o fenômeno da compra de votos e corrupção. Visto que muitos eleitores agem de forma interessada, apoiando os partidos que lhes oferecem algo em troca, institucionalizando de certa forma o mal da corrupção e compra de votos.

A compra de votos é um mal que assombra a maioria dos países com democracia não consolidada ou de recém-democratização, e suspeita-se que Cabo Verde não está imune a essa prática. Quando se fala da compra de votos, refere-se à questão da manipulação de consciências dos eleitores perante o cenário eleitoral contribuindo assim para que as eleições se tornem sujas e corruptas.

No estudo do cientista político João Silvestre Alvarenga sobre a fraude e corrupção eleitoral nas eleições legislativas de 2011, afirma-se que existe compras de votos em Cabo Verde, tratando o fenômeno como sendo uma realidade nas eleições realizadas no País ${ }^{70}$. Neste estudo se chegou à conclusão de que a percentagem de votos comprados foi suficiente para eleger entre um e dois deputados no círculo eleitoral da Praia, sendo que 6\% destes eleitores receberam dinheiro ou foram pressionados para votarem em determinado partido político. Assim, no círculo eleitoral da Praia, de 3\% a 9\% dos eleitores venderam o seu voto nas eleições legislativas de 2011. Alvarenga sustenta que o perfil das pessoas que venderam seu voto são as pessoas mais humildes e pobres, enfatizando que quando há compra de votos se desvaloriza o eleitor, igualandoo a uma mercadoria pondo em causa um dos princípios da democracia que é a liberdade e transparência (Alvarenga, 2011).

\footnotetext{
69 “Pensando na ultima eleição legislativa de 2011, Você participou de uma reunião de campanha eleitoral ou comício eleitoral?"

${ }^{70}$ Pesquisa de opinião, intitulado fraude e corrupção nas eleições legislativa de 2011 no círculo eleitoral da Praia, realizado por Prof. João Alvarenga (In jornal Expresso das Ilhas, no505, 3 de Agosto de 2011).
} 
Outro estudo ${ }^{71}$ coordenado pela polítoga Roselma Évora intitulado de "Estudo sobre a participação eleitoral em Cabo Verde: Uma perspectiva de Género" veio apresentar os dados que nos permite suspeitar da existência de compra de votos em Cabo-Verde. Como resultado da pesquisa $11 \%$ dos inqueridos afirmou já terem sido alvos de aliciamento com dinheiro ou bens matérias para votar em um determinado partido político.

Quando se fala de compras de votos, fala-se em dinheiro ou algum recurso de poder que é exercido ou oferecido aos eleitores. Durante a eleição legislativa de 2011, Lídio Silva então presidente da UCID, veio a público repudiar pedindo a intervenção das autoridades judiciais perante esse cenário de compra de votos que se verificou durante a eleição legislativa de 2011. Ele realçou que é o dinheiro que ganha às eleições em Cabo Verde. As legislativas 2011 serviram para os "violadores" lançarem “descarada" compra de votos sem precedentes. (In Jornal “A Nação" n¹81. Fevereiro de 2011).

O então líder do PSD, João Além, acredita que existe compra de votos em Cabo Verde. Ele realçou que a compra de votos durante as eleições legislativas de 2011 condicionaram os resultados eleitorais. Afirma, ainda que os maiores partidos, que normalmente formam o governo, não fazem nada para evitar a compra de consciência (In jornal, A Nação, nº180, fevereiro de 2011). Um artigo escrito no jornal Asemana, durante as eleições legislativas de $2001^{72}$, apresenta o método tradicional de comprar votos da seguinte maneira: convencer um eleitor a votar num determinado partido em troca de dinheiro ou favores e benefícios e para isso o delegado do partido e o eleitor combinam um preço pelo voto. No dia das eleições o delegado do partido entrega um boletim votado, cabendo ao eleitor ir à mesa de votação e depositar o boletim e voltar com o comprovante (boletim não votado que recebeu na mesa votação) de que votou no partido e receber o valor combinado. Existem outras formas para a compra de votos que foram denunciadas durante as eleições legislativas realizadas em Cabo Verde. Entre elas vale lembrar a distribuição de gêneros alimentícios, distribuição de materiais de

\footnotetext{
${ }^{71}$ O estudo abarcou 1.261 inqueridos, entre os seis maiores círculos eleitorais (Santo Antão, São Vicente, Sal, Fogo, Santiago Norte e Santiago Sul).

72 In Jornal Assemana, n-488. Janeiro de 2001.
} 
construção civil, apoio no pagamento de mensalidades escolares, construção de habitações, entre outras práticas.

Muitos analistas entendem que essa prática ainda acontece em Cabo Verde, devido à ineficiência do sistema de votação, tendo em conta que ainda se vota num boletim. Alguns estudiosos e políticos têm defendido o sistema de votação eletrônica, como sendo mais eficiente e eficaz. Entendemos que essa prática de troca de boletim poderá ser abolida com o sistema de votação eletrônica, instalado em vários países de democracia avançada e que tem proporcionado resultados eficientes. 


\section{Capítulo 4}

\section{Conclusão}

A legislação eleitoral cabo-verdiana afirma que apenas os partidos políticos podem se apresentar nas eleições legislativas, através de listas fechadas e bloqueadas. Assim, os partidos políticos se tornaram um agente importante e necessário no sistema partidário cabo-verdiano. $\mathrm{O}$ formato do sistema partidário depende de um conjunto de fatores, dentre os quais os mais importantes são o sistema eleitoral, e o sistema de financiamento partidário (isenções fiscais e subvenções estatais, tanto para o seu funcionamento como para as campanhas eleitorais). Este estudo tentou encontrar uma explicação complementar à que vem sendo oferecida na opinião pública e entre os próprios partidos. No caso, o insucesso dos pequenos partidos se deve a fatores sociais que deveriam ser melhor compreendidos, mas que remetem ao alto grau de satisfação que a população tem como o atual formato do sistema partidário.

De certa forma, isso não vai contra a ideia da dependência do estado e não comprova os efeitos da cartelização, fenômeno hoje presente em vários partidos no mundo, de acordo com Katz e Mair (1995). A questão da cartelização dos partidos políticos em Cabo Verde pode ser um fenômeno bem presente, mas isso não deve estar relacionado necessariamente ao modelo de financiamento dos partidos. Neste caso, o elemento explicativo pode ser encontrado em como se deu a transição para a democracia. Com a transição política do mono ao multipartidário, esperava-se o sucesso dos demais partidos, mas apenas dois partidos conseguiram firmar-se no seio do eleitorado cabo-verdiano. Apesar do surgimento de novas forças partidárias ao longo do tempo, elas nunca chegaram a ameaçar a supremacia dos dois grandes partidos.

A afirmação desses dois partidos no seio da sociedade cabo-verdiana pode ser explicada pelo contexto do seu surgimento. O PAICV foi um partido que surgiu no contexto de luta de libertação nacional e se intitula como o partido libertador que lutou pela independência do país. O MPD, por sua vez, surgiu num contexto em que o mundo assistia as grandes mudanças em vários países rumo ao multipartidarismo. Assim, o partido veio se afirmar como partido que trouxe a democracia e liberdade ao povo Cabo-verdiano. A UCID é um partido que surgiu logo depois da independência (1978), porém não conseguiu legalizar-se a tempo de apresentar candidatos na primeira eleição 
legislativa (1991) no país. Apesar de já ter uma base partidária no exterior, mas não conseguiu implantar no território cabo-verdiano a tempo.

Acreditamos que o regime jurídico dos partidos políticos, que foi aprovado no processo da transição, fruto da negociação entre os dois partidos (MPD e PAICV) dificultou o processo da legalização da UCID e, em ultima instância, veio a prejudicar a possibilidade de institucionalização de outras forças políticas ao longo do tempo. No caso específico um dos requisitos exigidos para o partido ser legalizado seriam quinhentas assinaturas de pessoas em pleno gozo de direitos civis e políticos numa altura em que o PAICV se identificava como sendo o partido da Independência e o MPD era visto como sinal da esperança.

È fato que hoje em dia em Cabo Verde os pequenos partidos não concentram grandes preferências eleitorais, fortalecendo assim o bipartidarismo. $O$ fato da proximidade das pessoas com algum partido ser forte não representa quaisquer esperanças aos pequenos partidos. Dessa forma, os vários pedidos da revisão do sistema de financiamento dos partidos políticos podem ser vistos sob outra perspectiva. Apesar de a nossa hipótese indicar que outros fenômenos têm explicado o insucesso para além das questões relativas ao financiamento é claro que o atual modelo não proporciona aos pequenos partidos condições de desenvolver as atividades políticas que os eleitores esperam. O financiamento partidário tem o seu peso forte nesse processo, possibilitando assim afirmar que seja um dos pontos fortes que explicam o insucesso eleitoral dos pequenos partidos. $\mathrm{O}$ atual formato partidário não nos parece que se vá alterar em curto prazo, devido às questões analisadas. $\mathrm{O}$ insucesso dos pequenos partidos parece estar relacionado à falta de apoio da população e as demais variáveis institucionais, nomeadamente o sistema eleitoral e as preferências eleitorais. 


\section{Bibliográfia}

\section{Livros e artigos}

AFROBAROMETER (2011). "Survey Overview. The quality of democracy and governance in Cape verde." Afrobarometer Round 5, 2011.

(2005). "A qualidade da Democracia em Cabo Verde". Praia.

(2012). "Survey Overview. The quality of democracy and governance in Mozambique” Afrobarometer Round 5, 2012.

(2013) "Survey Overview. The quality of democracy and governance in Algeria” Afrobarometer Round 5,2013.

(2012) "Survey Overview. The quality of democracy and governance in Gana” Afrobarometer Round 5,2012.

(2011) "Survey Overview. The quality of democracy and governance in Benin” Afrobarometer Round 5, 2011.

(2013) "Survey Overview. The quality of democracy and governance in Senegal” Afrobarometer Round 5, 2013.

(2011) "Survey Overview. The quality of democracy and governance in South Africa” Afrobarometer Round 5, 2011.

ARAÚJO, Raúl C. (2000) "Os sistemas de governo de transição democrática nos PALOP" Coimbra Editora. Boletim da faculdade direito, Studia Juridica 53.

ALMADA, David.(2011) "A Construção do Estado e a Democratização do poder em Cabo Verde" Cidade da Praia.

ALMADA, David Hopffer (2011) “A construção do estado e a democratização do poder em Cabo Verde".Tipografica Santos. Cidade da Praia.

BIENZEN, Van Ingrid (2004). "Political Parties as public utilities". In Party politics. Londom.

CAHEN, Michael. (1991) “Arquipélagos da alternância”. Revista Internacional de Estudos Africanos, №14-15. Lisboa, Jan/Fev, pp113-144.

CARDOSO, Humberto (1993). “O Partido Único em Cabo Verde”. Praia: Imprensa Nacional.

CARVALHO, Luís Pedro (2009)."O Movimento dos Capitães, o MFA e o 25 Abril: Do Marcelismo à Queda do Estado Novo". Dissertação do Mestrado. Universidade Lusófona de Humanidades e Tecnológica. Lisboa.

CHABAL, Patrick. (2005) "Power in Africa Reconsidered". In: ENGEL U and O1SEN, G (org). The African Exception. Aldershot: Ashgate. 
COSTA, Daniel Henrique (2001). "O Semi-presidencialismo em Cabo Verde (19912000)". Dissertação de Mestrado - Instituto Universitário de Pesquisas do Rio de Janeiro, Rio de Janeiro.

(2003). "Sistema Eleitoral Cabo-verdiano (1991-2001): com um olhar sobre o mundo". In, Direito e Cidadania, n¹6/17, 2003. 253-300.

COUTINHO, Angela. (2010) "Da luta de libertação nacional ao governo da República de Cabo Verde: as trajetórias dos membros de governo de 1975 a 1991”, $7^{\circ}$ congresso ibérico de estudos africanos, Lisboa.

D’ALMEIDA, Manfredini Noely (2001). "Financiamento político de campanhas e partidos: a experiência mundial sobre a prestação de contas". Disponível em:http://www.paranaeleitoral.gov.br/artigo_impresso.php?cod_texto=210.

DUVERGER, Maurice (1970). “Os Partidos Políticos”. Editora UNB, Brasília.

ÉVORA, Roselma (2001) “Abertura política e o processo da transição democrática em Cabo Verde”. Dissertação do Mestrado. Universidade de Brasília. Brasília 2001.

(2004). "Cabo Verde: A abertura política e a transição para a democracia”. Spleen Edições, Praia.

(2009). "Poder Legislativo no regime democrático em Cabo Verde”. Tese de Doutorado- Universidade de Brasília, Brasília 2009.

(2013) "Cabo Verde: Democracia e Sistema de Governo". In: Montalvão Sarmento, Suzano Costa (org.), Entre África e a Europa: Nação, Estado e Democracia em Cabo Verde.

ÉVORA, Roselma; RAMOS, Noemi (2013). "Estudo sobre a participação eleitoral em Cabo Verde: Uma perspectiva de Género”. Relatório Final. PNUD/UNICEF/UNFPA.

FONSECA, Jorge Carlos. (1990), "O sistema de Governo na Constituição CaboVerdiana". Lisboa.

FRANCO, Paulo Fernandes (2009), "Amílcar Cabral: a palavra falada e a palavra vivida". Dissertação do Mestrado - Departamento de História - Universidade São Paulo. GUNLICKS, Arthur (1988). "Campaign and Party Finance in the West German "Party State"in the review of politics. Vol 50, $\mathrm{N}^{\circ} 1$.

HUNTINGTON, Samuel. (1994) "A Terceira Onda: democratização no final do sex. XX”. São Paulo: Ática.

JACOBSON, Gary (1978)" the effects of campaign spending in Congressional Elections". In the American Political Science Review, vol. 72, No.2, pp, 469-491.

JALALI, Carlos. (1997) "Partidos e democracia em Portugal 1974-2005”. Lisboa: imprensa de ciências sociais (ICS).

JON Pierre; LARS Svåsand; ANDERS Widfeldt (2000): "State subsidies to political parties: Confronting rhetoric with reality", West European Politics, 23:3, 1-24.

KATZ, Richard e MAIR, Peter (eds.) (1995). "Changing Models of Party Organisation: The Emergence of the Cartel Party”. In, Party Politics, vol. 1, n. ${ }^{\circ} 1$. 
LIPHART, Arend. (2003) "Modelos de Democracia: Desempenho e Padrões de Governo em 36 países": rio de Janeiro: civilização brasileira.

KRASNO, Jonathan; GREEN, Donald (1988) "salvation for the spendthrift incumbent: Reestimating the Effects of campaign Spending in House Elections". In Amarican Journal of Political Science, vol 32. No 2 (Nov., 1988) pp, 884-907.

LARANJEIRO Catarina, (2014). "Amílcar Cabral: o que foi e o que dele faremos." Mestres do mundo, trabalho final do seminário, conhecimentos, sustentabilidade e justiça cognitiva.

(Disponível:http://alice.ces.uc.pt/en/wpcontent/uploads/2014/03/Mestres_do_Mundo_Amilcar_Cab ral2.pdf. acessado em 08.12.2014).

LEVITT, Steven (1994) "Using Repeat Challengers to Estimate the effect of campaign spending o Elections Outcomes in the U.S.House". in Journal of political Economy, vol.102 no 4 (Aug, 1994) pp. 777-798.

LIMA, Aristides. (1991), "Reforma Política em Cabo Verde: Do Paternalismo à Modernização do Estado”. Praia, Grafedito, Edição do Autor.

LIMA, Aristides e Mirko Hempel. (2002), "Democracia, Sistemas Eleitorais e Economia Social". Praia, Assembleia Nacional.

MOGOWONGO, Augustine et all. (2012) "Regulating political party financing: some insights from the praxis". IDEA e NIMD.

NICOLAU, Jairo; SCHMITT, Rogério (1995) "Sistema eleitoral e sistema partidário". Luva Nova n³6. São Paulo.

NICOLAU, Jairo. (1996) "Multipartidarismo e Democracia”. Rio de Janeiro: FGV. (2004) “Sistemas eleitorais”. 5 edição. Rio de Janeiro: Editora FGV.

PEIXOTO, V. de M.(2009) "Financing of campaigns: Brazil in comparative perspective". Perspectivas, São Paulo, v.35, p.91-116, Jan./June.

RAMOS, Arceolinda Monteiro (2012). "Partidos Políticos na Democracia CaboVerdiana: Um estudo de caso (1991-2011)". Dissertação de Mestrado- Universidade de Cabo Verde, Praia, 2012.

RODRIGUES, Ricardo. (2012) "Financiamento de partidos políticos e fundos partidários. Subvenções públicas em países selecionado"s. Brasília a49 n.193 jan/mar.

RUBIO, Delia F. (2005) "Financiamento de partidos e campanhas - fundos públicos versus fundos privados" in Novos Estudos Cebrap, n73, Nov. pp, 5-15.

SANCHES, Edalina. (2013) "Institucionalização do Sistema Partidário e Democratização em Cabo Verde (1991-2011)”. In: Montalvão Sarmento, Suzano Costa (org.), Entre África e a Europa: Nação, Estado e Democracia em Cabo Verde. 
(2010) "Partidos e Democracia: Cabo Verde e São Tomé e Príncipe em perspectiva comparada" $7^{\circ}$ congresso ibérico de estudos africanos, Lisboa.

(2012) « Institucionalização dos Sistemas Partidários na África Lusófona - O caso cabo-verdiano », Cadernos de Estudos Africanos [Online], 20 | 2010, posto online no dia 22 Julho 2012, consultado o 16 Maio 2014. URL : http://cea.revues.org/161; DOI : 10.4000/cea.161.

SANTOS, Daniel. (2013) “Uma Vaga, duas Transições Políticas”. In: Montalvão Sarmento, Suzano Costa (org.), Entre África e a Europa: Nação, Estado e Democracia em Cabo Verde.

SANTOS, Fabiano. (2000) "Escolhas institucionais e transição por transação: sistemas políticos de Brasil e Espanha em perspectiva comparada". In dados, tio de janeiro vol $43, \mathrm{n}^{\circ} 4$.

SAMUELS, David (2001) Incumbents and Challengers on a level playing field: Assensssing the impat of Campaign Finance in Brazil. In the Journal of Politics, Vol. 63, No 2 (may, 2001=, pp 569-584.

SARTORI, Giovanni. (1982) "Partidos e sistemas partidários". Rio de Janeiro: Zahar; Brasília: UnB.

SEMEDO et. all (2007). "Estudo Sociológico sobre as Eleições Legislativas e Presidenciais de 2001 e 2006." DGAE, Praia.

SILVEIRA, Onésimo (1997). “Cabo Verde: Do Partido-Estado ao Partido do Estado”. Revista Direito e Cidadania, n.o 2, Nov.

SPECK, Bruno. (2013) "Recursos, partidos e eleições: o papel do financiamento privado, do Fundo Partidário e do horário gratuito na competição política no Brasil ". Draft para coletânea sistema político Brasileiro, ed.2014. Boston.

(2002) "como financiar a competição política? Concepções contemporâneas, ilustrações do caso da Alemanha e perspectivas para a situação no Uruguay. In Dinero y política. El financiamiento de los partidos en la democracia.

(2006) "o financiamento de campanhas eleitorais" in Leonardo Avritzer, Fátima Anastásia (orgs.): Reforma Política no Brasil, Belo Horizonte, Editora UFMG, 2006, p.153-158.

SPECK, Bruno; MANCUSO, Wagner.(2013) “o que faz a diferença? Gastos de campanha, capital político, sexo e contexto municipal nas eleições para prefeito em 2012. Cadernos adenauer XIV, $\mathrm{n}^{\circ} 2$.

STRATMANN, Thomas (2005). "Some talk: Money in politics". A (partial) review of the literature . Pubic choice (2005) 124: 135-156.

WALECKI, Marcin; ZAMORA, Kevin Casas, et all. "Public funding solutions for political parties in Muslim-Majority Societes". IFES. 
WOOLLACOTT, John. (1983) "A luta pela libertação nacional na Guiné-Bissau e revolução em Portugal" analise social, vol. XIX (77-78-79), -3º $4^{\circ}, 5^{\circ} 1131-1155$ University of Manchester.

ZAMORA, Kevin Casas. (2006) "State Funding and Campaign Finance Practices in Uruguay" Cuad. CLAEH vol.1 no.se Montevideo.

ZOVATTO, Daniel (2005). "Financiamento dos Partidos e Campanhas Eleitorais na América Latina: uma análise comparada." Revista Opinião Pública. Volume 11, n 2 , outubro, Campinas.

\section{Fontes primárias e entrevistas}

ASSEMBLEIA NACIONAL. Anuário parlamentar, 2010-2011. Praia. 2011.

Boletim Legislativo (Leis aprovadas pela NA de 1975-

2010). Direcção de Serviços de Documentão e Informação Parlamentar. Praia, 2010.

\section{Entrevistas}

MONTEIRO, António (Presidentes da UCID, atualmente). Realizada por mim ao presidente da UCID, via email em Julho de 2014.

MONTEIRO, António (Presidentes da UCID, atualmente). Realizada pela professora assistente da Universidade de Cabo Verde, em Setembro 2011.

\section{Legislação}

CABO VERDE, Constituição Da República de Cabo verde. Direcção dos serviços parlamentares: Praia, 1980.

Constituição Da República de Cabo verde (revisão). Direcção dos serviços parlamentares: Praia, 2010. $1^{\text {a }}$ edição.

Regimento da Assembleia Nacional. Boletim Oficial, praia, I

Série, N²0, 3 Jul. 2000.

Lei nº92/V/99, de 8 de Fevereiro de 1999. Código Eleitoral da

República de Cabo Verde.

Lei $n^{\circ}$ 86/III/90, de 06 de Outubro de 1990. Lei que define O regime Jurídico dos partidos políticos, Praia. 1990.

Lei n¹02/V/99, de 19 de Abril de 1999. Regime Jurídico dos partidos políticos, Praia. 1999.

Lei nº9/III/90, de 27 de Outubro de 1990. Direito de Antena e de resposta política.

Lei n²/III/90, de 29 de Setembro de 1990. Altera a Constituição da República de Cabo verde. Praia. 1990 
Lei n$^{\circ} 1 /$ VII/75, de 5 de Julho de 1975. Lei da Organização

Política do Estado, Praia. 1975.

Lei nº5/II/84, de 31 de Dezembro de 1984. Lei eleitoral para a Assembleia Nacional Popular, Praia. 1984.

Lei nº7/III/90, de 13 de Outubro de 1990. Alteração da lei eleitoral para a Assembleia Nacional Popular, Praia. 1990.

\section{Comissão Nacional das Eleições (CNE)}

Contas Eleitorais das Legislativas de 14 Janeiro de 2001, in Boletim Oficial da República de Cabo Verde, I Série, N44, 29 de Outubro de 2001.

Contas Eleitorais das Legislativas de 22 de Janeiro de 2006, in Boletim Oficial da República de Cabo Verde, I Série, N50, 28 de Dezembro de 2006.

Resultados das Eleições Legislativas de 14 de Janeiro de 2001, in Boletim Oficial da República de Cabo Verde, I Série, N. ${ }^{\circ}$ 2, 22 de Janeiro de 2001.

Resultados das Eleições Legislativas de 22 de Janeiro de 2006, in Boletim Oficial da República de Cabo Verde, I Série, №11, 14 de Março de 2006.

Resultados das Eleições Legislativas de 6 de Fevereiro de 2011, in Boletim Oficial da República de Cabo Verde, I Série, N. ${ }^{\circ} 7,19$ de Fevereiro de 2011.

Contas Eleitorais das legislativas de 06 de Fevereiro de 2011, In Boletim Oficla da República de Cabo Verde, II Série, N46, 30 de Novembro de 2011.

\section{Artigos em Jornais}

"Endividados à espera do governo" Eduino Santos. Expresso das Ilhas- 02.03.2005.

"O financiamento dos partidos políticos" Jose Luís livramento Expresso das Ilhas, 1602. 2005

"Financiamento da actividade politica" José António dos Reis. Analise. Horizonte, 17 de Março de 2005.

"Há compra de votos em Cabo Verde" (estudo sobre fraude e corrupção eleitoral, feito entre 16-22maio de 2011). Expresso das Ilhas, nº505- 03 de agosto de 2011.

“Especial eleição legislativa de 1995”. Jornal Assemana, 20 de Novembro de 1995.

“Eleições legislativas fraudulentas” pag. 2 A nação, nº181- semanário. 17 a 23/02/2011

"Legislativas, para acabar com a bipolarização, UCID quer seis deputados". A nação/semanário/ nº178 - 27/01 a 02/02/2011

$n^{\circ} 179,03$ a 09 de fevereiro de 2011.

"Eleição legislativa de 2001". Suplemento da Assemana, no 488, 05/12 de Janeiro de 2001 .

“As pessoas estão cansadas da bipolarização" Horizonte, 12 de Janeiro de 2006 
"Eleições legislativa de 1995". Suplemento de A Semana n²34. 04 de Dezembro de 1995

"PRD quer dinheiro do estado para todos os partidos" José Luís Livramento. Politica 28.11.2002

\section{Websites}

http://africanelections.tripod.com/, - acessado nos dias 15 a 20.11.2014.

http://www.afrobarometer.org/- acessado nos dias 10 a 30.11.2014.

http://www.idea.int/ - Acessado em 09.11.2014.

http://www.portaldecaboverde.com/bin/app?do=Pubpara\&action=detalhe\&id=712.

Acessado em 20.10.2014.

http://www.jsn.com.cv/index.php/nacional/896-eleicoes-em-cabo-verde-estudo-

confirma-compra-de-votos, acessado em 08.10.2014.

http://www.ateneulivros.com/website/2014/10/p-a-i-g-c-unidade-de-luta/, acessado em 1011-2014

http://www.dw.de/cronologia-1970-1974-da-intensifica\%C3\%A7\%C3\%A3o-da-lutaarmada-\%C3\%A0-revolu\%C3\%A7\%C3\%A3o-dos-cravos/a-17280935, acessado em 09.11.2014. 